\title{
₹USGS
}

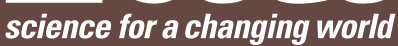

Prepared in cooperation with the Bureau of Reclamation

Geologic Framework and Hydrogeology of the Middle Carson River Basin, Eagle, Dayton, and Churchill Valleys, West-Central Nevada

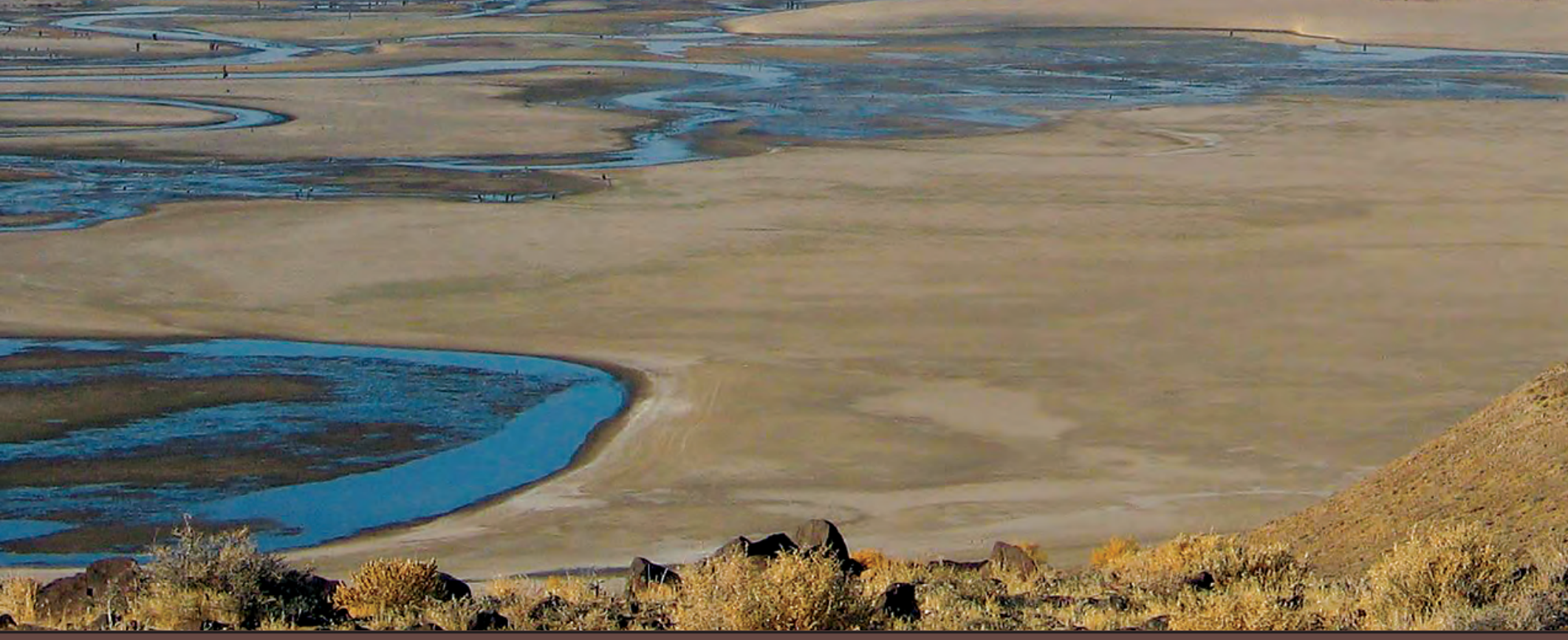

Scientific Investigations Report 2011-5055

U.S. Department of the Interior

U.S. Geological Survey 
Cover: Photograph of groundwater seepage east of Silver Springs, Nevada, filling the thalweg of the Carson River channel on the floor of Lahontan Reservoir, looking west with Churchill Butte in the background (Photograph taken by Douglas K. Maurer, U.S. Geological Survey, October 29-November 4, 2008. 


\section{Geologic Framework and Hydrogeology of the Middle Carson River Basin, Eagle, Dayton, and Churchill Valleys, West-Central Nevada}

By Douglas K. Maurer

Prepared in cooperation with the Bureau of Reclamation

Scienific Investigations Report 2011-5055 


\title{
U.S. Department of the Interior \\ KEN SALAZAR, Secretary \\ U.S. Geological Survey \\ Marcia K. McNutt, Director
}

\author{
U.S. Geological Survey, Reston, Virginia: 2011
}

For more information on the USGS - the Federal source for science about the Earth, its natural and living resources, natural hazards, and the environment, visit http://www.usgs.gov or call 1-888-ASK-USGS.

For an overview of USGS information products, including maps, imagery, and publications, visit http://www.usgs.gov/pubprod

To order this and other USGS information products, visit http://store.usgs.gov

Any use of trade, product, or firm names is for descriptive purposes only and does not imply endorsement by the U.S. Government.

Although this report is in the public domain, permission must be secured from the individual copyright owners to reproduce any copyrighted materials contained within this report.

Suggested citation:

Maurer, D.K., 2011, Geologic framework and hydrogeology of the middle Carson River Basin, Eagle, Dayton, and Churchill Valleys, West-Central Nevada: U.S. Geological Survey Scientific Investigations Report 2011-5055, 62 p. 


\section{Contents}

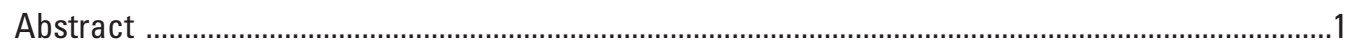

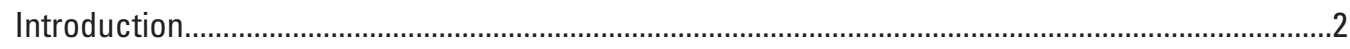

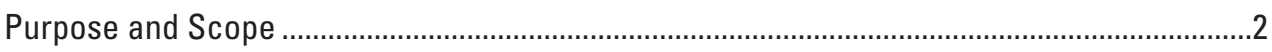

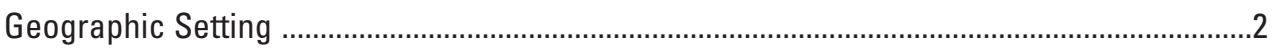

Previous Hydrologic Investigations .................................................................................. 4

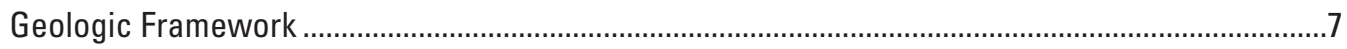

Hydrogeologic Units and Geologic History ...........................................................................

Geologic Structure................................................................................................................... 13

Thickness of Tertiary and Quaternary Rocks and Sedimentary Units .....................................14

Thickness of Quaternary Basin-Fill Sediments.....................................................................17

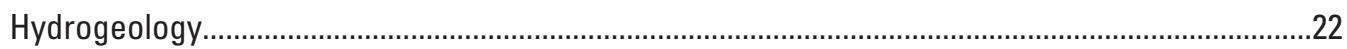

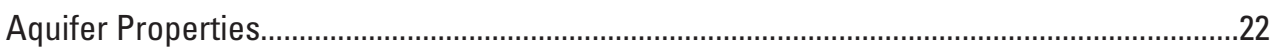

Groundwater Levels and Regional Groundwater Flow ......................................................30

Groundwater and Surface-Water Interactions ....................................................................38

Findings in Previous Studies .....................................................................................................38

Insights Gained by Analyses of Recent Data ........................................................................39

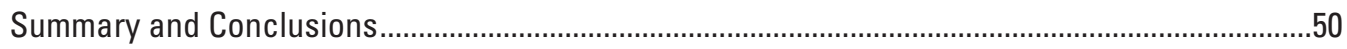

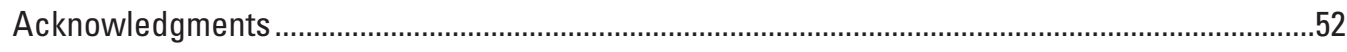

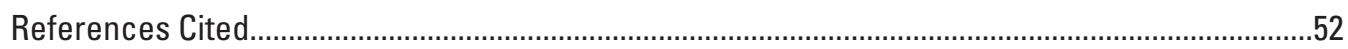

Appendix A. Location of Selected Wells Encountering Bedrock and Deep Wells Not Encountering Bedrock....................................................................................................... 57

Appendix B. Location of Selected Wells Logs Describing Gravel and Cobble, and Clay Layers Greater than 50 Feet Thick, Layer Depths, and Thicknesses. 


\section{Figures}

Figure 1. Map showing location of the Carson River basin, hydrographic areas within the basin, and selected geographic features, Nevada and California

Figure 2. Maps showing selected geographic features of the middle Carson River basin, Nevada

Figure 3. Map showing hydrogeologic units, structural features, and Quaternary faults in the middle Carson River basin, Nevada ....

Figure 4. Map showing early and late Pleistocene high stands of ancient Lake Lahontan and locations of selected driller's logs describing coarse gravel and cobble, and clay layers greater than 50 feet thick, middle Carson River basin, Nevada $\quad \ldots 12$

Figure 5. Map showing estimated thickness of Tertiary and Quaternary rocks and sediments, middle Carson River basin, Nevada

Figure 6. Map showing estimated altitude of the top of pre-Cenozoic rocks, and groundwater altitude at selected wells, middle Carson River basin, Nevada

Figure 7. Map showing location of gravity stations used to estimate the thickness of Quaternary basin-fill sediments, and complete Bouguer gravity anomaly, middle Carson River basin, Nevada

Figure 8. Graph showing relation between residual gravity and thickness of unconsolidated basin-fill sediments from lithologic descriptions on driller's logs for selected wells, middle Carson River basin, Nevada

Figure 9. Maps showing estimated thickness of unconsolidated basin-fill sediments, middle Carson River basin, Nevada

Figure 10. Map showing location of slug tests and estimates of hydraulic conductivity, and location of aquifer tests and estimates of transmissivity, middle Carson River basin, Nevada

Figure 11. Graph showing relation between specific capacity and transmissivity, Carson and Dayton Valleys, Nevada

Figure 12. Map showing estimates of transmissivity near selected wells calculated from relation between specific capacity and transmissivity, and information found in driller's logs for wells yielding greater than 30 gallons per minute, middle Carson River basin, Nevada

Figure 13. Map showing distribution of the estimated potential range of specific yield for the middle Carson River basin, Nevada

Figure 14. Maps showing water-level altitude in April 2009 at selected wells, contours of water-level altitude, and areas of water-level decline in Eagle Valley and Riverview and Moundhouse subbasins, Carson Plains subbasin, Stagecoach and Bull Canyon subbasins, and Churchill, northern Mason, and western Lahontan Valleys, middle Carson River basin, Nevada

Figure 15. Map showing location of seepage measurement sites and location of wells with warm water in the Carson Plains subbasin, middle Carson River basin, Nevada

Figure 16. Map showing concentrations of deuterium in streamflow and groundwater in the subbasins of Dayton Valley and Churchill Valley, middle Carson River basin, Nevada 


\section{Figures-Continued}

Figure 17. Map showing location of Lyon County monitoring wells and municipal supply wells in the Carson Plains subbasin, middle Carson River basin, Nevada.......... 45

Figure 18. Graphs showing variations in groundwater levels compared with variations in streamflow of the Carson River at Dayton for wells close to the Carson River, and wells distant from the Carson River, middle Carson River basin, Nevada ..... 46

Figure 19. Graphs showing variations in groundwater levels compared to variations of the stage of Lahontan Reservoir, middle Carson River basin, Nevada

Figure 20. Photographs of groundwater seepage east of Silver Springs, Nev., filling the thalweg of the Carson River channel, looking west with Churchill Butte in the background, diffuse seepage through a continuous seepage face, and concentrated flow in an individual seepage channel, middle Carson River basin, Nevada

\section{Tables}

Table 1. Summary of information for slug tests in Riverview, Carson Plains, and Stagecoach subbasins, and Churchill Valley

Table 2. Summary of information for aquifer tests in the Riverview, Carson Plains, and Stagecoach subbasins

Table 3. Location, construction, and lithologic information for 2-inch monitoring wells

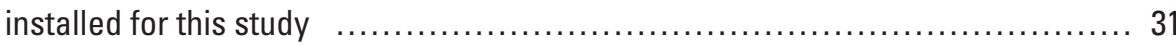

Table 4. Location of seepage measurement sites, Middle Carson River, Nevada .......... 41

Table 5. Seepage measurements and calculated gains and losses $\ldots \ldots \ldots \ldots \ldots \ldots \ldots \ldots 42$

Table 6. Specific conductance and deuterium concentration of streamflow sampled

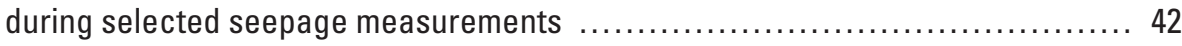




\title{
Conversion Factors, Datums, and Abbreviations and Acronyms
}

\author{
Conversion Factors
}

Inch/Pound to SI

\begin{tabular}{|c|c|c|}
\hline Multiply & By & To obtain \\
\hline \multicolumn{3}{|c|}{ Length } \\
\hline inch (in.) & 2.54 & centimeter $(\mathrm{cm})$ \\
\hline inch (in.) & 25.4 & millimeter (mm) \\
\hline foot $(\mathrm{ft})$ & 0.3048 & meter (m) \\
\hline mile (mi) & 1.609 & kilometer (km) \\
\hline \multicolumn{3}{|c|}{ Area } \\
\hline acre & 4,047 & square meter $\left(\mathrm{m}^{2}\right)$ \\
\hline acre & 0.4047 & hectare (ha) \\
\hline acre & 0.4047 & square hectometer $\left(\mathrm{hm}^{2}\right)$ \\
\hline acre & 0.004047 & square kilometer $\left(\mathrm{km}^{2}\right)$ \\
\hline square mile $\left(\mathrm{mi}^{2}\right)$ & 259.0 & hectare (ha) \\
\hline square mile $\left(\mathrm{mi}^{2}\right)$ & 2.590 & square kilometer $\left(\mathrm{km}^{2}\right)$ \\
\hline \multicolumn{3}{|c|}{ Volume } \\
\hline gallon (gal) & 3.785 & liter (L) \\
\hline gallon (gal) & 0.003785 & cubic meter $\left(\mathrm{m}^{3}\right)$ \\
\hline gallon (gal) & 3.785 & cubic decimeter $\left(\mathrm{dm}^{3}\right)$ \\
\hline million gallons (Mgal) & 3,785 & cubic meter $\left(\mathrm{m}^{3}\right)$ \\
\hline acre-foot (acre-ft) & 1,233 & cubic meter $\left(\mathrm{m}^{3}\right)$ \\
\hline acre-foot (acre-ft) & 0.001233 & cubic hectometer $\left(\mathrm{hm}^{3}\right)$ \\
\hline \multicolumn{3}{|c|}{ Flow rate } \\
\hline acre-foot per day (acre-ft/d) & 0.01427 & cubic meter per second $\left(\mathrm{m}^{3} / \mathrm{s}\right)$ \\
\hline acre-foot per year (acre-ft/yr) & 1,233 & cubic meter per year (m³/yr) \\
\hline acre-foot per year (acre-ft/yr) & 0.001233 & cubic hectometer per year (hm3/yr) \\
\hline foot per second (ft/s) & 0.3048 & meter per second $(\mathrm{m} / \mathrm{s})$ \\
\hline foot per day (ft/d) & 0.3048 & meter per day $(\mathrm{m} / \mathrm{d})$ \\
\hline cubic foot per second $\left(\mathrm{ft}^{3} / \mathrm{s}\right)$ & 0.02832 & cubic meter per second (m³/s) \\
\hline $\begin{array}{l}\text { cubic foot per second per square mile } \\
{\left[\left(\mathrm{ft}^{3} / \mathrm{s}\right) / \mathrm{mi}^{2}\right]}\end{array}$ & 0.01093 & $\begin{array}{l}\text { cubic meter per second per square } \\
\text { kilometer }\left[\left(\mathrm{m}^{3} / \mathrm{s}\right) / \mathrm{km}^{2}\right]\end{array}$ \\
\hline cubic foot per day ( $\left.\mathrm{ft}^{3} / \mathrm{d}\right)$ & 0.02832 & cubic meter per day (m³/d) \\
\hline gallon per minute (gal/min) & 0.06309 & liter per second (L/s) \\
\hline gallon per day (gal/d) & 0.003785 & cubic meter per day (m³/d) \\
\hline $\begin{array}{l}\text { gallon per day per square mile } \\
\qquad\left[(\mathrm{gal} / \mathrm{d}) / \mathrm{mi}^{2}\right]\end{array}$ & 0.001461 & $\begin{array}{l}\text { cubic meter per day per square } \\
\text { kilometer }\left[\left(\mathrm{m}^{3} / \mathrm{d}\right) / \mathrm{km}^{2}\right]\end{array}$ \\
\hline million gallons per day (Mgal/d) & 0.04381 & cubic meter per second $\left(\mathrm{m}^{3} / \mathrm{s}\right)$ \\
\hline \multicolumn{3}{|c|}{ Mass } \\
\hline ounce, avoirdupois (oz) & 28.35 & gram (g) \\
\hline pound, avoirdupois (lb) & 0.4536 & kilogram (kg) \\
\hline \multicolumn{3}{|c|}{ Hydraulic conductivity } \\
\hline foot per day (ft/d) & 0.3048 & meter per day (m/d) \\
\hline \multicolumn{3}{|c|}{ Hydraulic gradient } \\
\hline foot per mile (ft/mi) & 0.1894 & meter per kilometer (m/km) \\
\hline \multicolumn{3}{|c|}{ Transmissivity } \\
\hline foot squared per day $\left(\mathrm{ft}^{2} / \mathrm{d}\right)$ & 0.09290 & meter squared per day $\left(\mathrm{m}^{2} / \mathrm{d}\right)$ \\
\hline
\end{tabular}




\title{
Conversion Factors, Datums, and Abbreviations and Acronyms- Continued
}

\author{
Conversion Factors
}

SI to Inch/Pound

\begin{tabular}{lccl}
\hline & Multiply & By & \multicolumn{1}{c}{ To obtain } \\
\hline inch (in.) & 2.54 & centimeter $(\mathrm{cm})$ \\
inch (in.) & 25.4 & millimeter $(\mathrm{mm})$ \\
\hline
\end{tabular}

Temperature in degrees Celsius $\left({ }^{\circ} \mathrm{C}\right)$ may be converted to degrees Fahrenheit $\left({ }^{\circ} \mathrm{F}\right)$ as follows:

$$
{ }^{\circ} \mathrm{F}=\left(1.8 x^{\circ} \mathrm{C}\right)+32
$$

Specific conductance is given in microsiemens per centimeter at 25 degrees Celsius $(\mu \mathrm{S} / \mathrm{cm}$ at $\left.25^{\circ} \mathrm{C}\right)$.

Concentrations of chemical constituents in water are given either in milligrams per liter (mg/L) or micrograms per liter $(\mu \mathrm{g} / \mathrm{L})$.

Concentrations of oxygen and deuterium isotopes are given in permil; parts per thousand of Vienna Standard Mean Ocean Water.

\section{Datums}

Vertical coordinate information is referenced to the North American Vertical Datum of 1988 (NAVD 88).

Horizontal coordinate information is referenced to the North American Datum of 1983 (NAD 83).

Altitude, as used in this report, refers to distance above the vertical datum.

Abbreviations and Acronyms

FWM Federal Water Master

NDWR Nevada Division of Water Resources

NWIS National Water Information System

USGS U.S. Geological Survey 
This page intentionally left blank. 


\title{
Geologic Framework and Hydrogeology of the Middle Carson River Basin, Eagle, Dayton, and Churchill Valleys, West-Central Nevada
}

\author{
By Douglas K. Maurer
}

\section{Abstract}

Changes in land use and water use and increasing development of water resources in the middle Carson River basin may affect flow of the river and, in turn, affect downstream water users dependent on sustained river flows to Lahontan Reservoir. The U.S. Geological Survey, in cooperation with the Bureau of Reclamation, began a study in 2008 of the middle Carson River basin, extending from Eagle Valley to Churchill Valley. Various types of geologic and hydrologic data were compiled from previous studies, collected for this study, and compiled and analyzed to provide a framework for development of a numerical model of the groundwater and surface-water flow systems of the basin.

Geologic units that are assumed to have similar hydrologic characteristics were grouped into hydrogeologic units comprised of consolidated rocks of pre-Cenozoic age that underlie a unit of consolidated volcanic rock and semiconsolidated sediments of Tertiary age. The principal aquifer in the study area is comprised of unconsolidated sediments of Quaternary age. The Quaternary sediments include alluvial fan, fluvial, and lake sediments, and were grouped into a basin-fill hydrogeologic unit that overlies the pre-Cenozoic and Tertiary hydrologic units.

The thickness of the combined section of Tertiary volcanic and sedimentary rocks and Quaternary basin-fill deposits previously was estimated to range from zero where pre-Cenozoic rocks are exposed to greater than 10,000 feet in the Bull Canyon subbasin, and greater than 6,000 feet on the western side of Churchill Butte and beneath the Desert Mountains. The thickness of Quaternary basin-fill sediments was estimated using gravity data and lithologic descriptions from driller's logs. The most permeable parts of basin-fill sediments are greater than 1,000 feet thick in the Carson Plains subbasin, greater than 800 feet and 600 feet thick in the western and northeastern parts of the Stagecoach subbasin, and greater than 1,000 feet and 800 feet thick in the northern and southern parts of Churchill Valley, respectively.

The distribution of aquifer properties was estimated for basin-fill sediments using slug-test and aquifer test data, and the lithologic descriptions of previously mapped geologic units. Slug-test data show hydraulic conductivity is greater than 10 to greater than 100 feet per day for fluvial sediments near the flood plain, less than 10 feet per day for basin-fill sediments outside the flood plain, and less than 1 foot per day for consolidated rocks. Estimates of transmissivity exceed 20,000 feet squared per day near the Carson River in Dayton, Churchill, and western Lahontan Valleys and in the northern part of the Stagecoach subbasin, and exceed 10,000 feet squared per day in the western part of Churchill Valley. A transmissivity of 90,000 feet squared per day was estimated from results of an aquifer test in the Carson Plains subbasin, indicating that permeable gravel and cobble zones at depths greater than 400 feet supplied water to the pumping well. Estimates of specific yield ranged from less than 1 to 2 percent for most consolidated rocks, from 1 to 15 percent for semiconsolidated Tertiary sediments, and from 10 to 40 percent for unconsolidated basin-fill sediments.

Water-level altitude maps based on measurements at about 300 wells in 2009 show water levels have declined as much as 70 feet since 1964 on the northwestern side of Eagle Valley, about 10 feet since 1995 near Dayton in the Carson Plains subbasin, and from 5 to 10 feet since 1982 in the western and northeastern parts of the Stagecoach subbasin and the northwestern part of Churchill Valley. The declines are likely the result of municipal and agricultural pumping. The maps show a groundwater divide between the Carson Plains and Stagecoach subbasins, and a continuous hydraulic gradient between the Stagecoach subbasin and Churchill Valley. Groundwater flow directions are uncertain beneath parts of the boundary of Churchill Valley. The altitude of the top of pre-Cenozoic rocks shows thick sections of saturated Tertiary rocks and sediments south of the Dead Camel Mountains and beneath the eastern part of the Desert Mountains through which groundwater flow between Churchill Valley, Mason Valley, and Lahontan Valley may take place. North of Lahontan reservoir, beneath the Dead Camel Mountains, and beneath the southern part of Adrian Valley, the altitude of preCenozoic rocks indicates groundwater flow between the three valleys is minimal. 
Streamflow measurements, supported by data on the deuterium content and specific conductance of surface-water samples, indicate a loss of Carson River streamflow in the Riverview subbasin, streamflow gains in the Moundhouse subbasin and the eastern part of the Carson Plains subbasin, and streamflow losses in the Bull Canyon subbasin.

Comparisons of fluctuations in groundwater levels to those in stream stage in the Carson Plains subbasin indicate that streamflow lost to infiltration from the Carson River, from irrigation ditches, and from irrigated fields is an important source of groundwater recharge. Fluctuations in groundwater levels compared with the stage of Lahontan Reservoir in Churchill Valley indicate losses to infiltration from the reservoir during high stage and groundwater seepage to the reservoir during low stage.

\section{Introduction}

Rapid population growth is increasing the demand for water resources in the Carson River basin (ig. 1). This growth is causing changes in land and water use, and the potential effects of these changes on groundwater and surface-water resources are uncertain. In the middle Carson River basin, upstream of Lahontan Reservoir, agricultural land is being urbanized, groundwater pumping is increasing, and surface water and groundwater currently being used for agriculture will likely be increasingly used for municipal supply. These changes in land and water use may cause changes in the rates and locations of groundwater recharge and discharge.

The groundwater and surface-water systems are thought to be well connected in the Carson River basin upstream of Lahontan Reservoir in Dayton and Churchill Valleys (Harrill and Preissler, 1994; Brown and Caldwell, 2004; Maurer and others, 2009). In these valleys, groundwater pumping may cause flow of the Carson River to Lahontan Valley to decrease over time, thereby affecting water users downstream. Conversely, land- and water-use changes that include the cessation of flood irrigation with diversions from the Carson River and the irrigation of land with treated effluent rather than by diversions from the Carson River may cause the flow of the river to increase (Maurer and Berger, 2007, p. 53).

An evaluation of groundwater flow and groundwater and surface-water interactions in the middle Carson River basin is needed to provide water managers with information for water-resources planning. In this study, the middle Carson River basin includes the hydrographic areas ${ }^{1}$ (HA) of Eagle

\footnotetext{
${ }^{1}$ The U.S. Geological Survey (USGS) and Nevada Division of Water Resources (NWDR) delineated formal hydrographic areas in Nevada systematically in the late 1960s for scientific and administrative purposes (Cardinalli and others, 1968). The official hydrographic-area names, numbers, and geographic boundaries continue to be used in USGS scientific reports and NWDR administrative proceedings and reports. Hydrographic-area boundaries generally coincide with drainage-area boundaries.
}

(HA104), Dayton (HA103), and Churchill Valleys (HA102) upstream of Lahontan Dam (fig. 1). The study area also includes the western part of the Carson Desert hydrographic area (HA101), which encompasses Lahontan Valley.

The U.S. Geological Survey (USGS), in cooperation with the Bureau of Reclamation (Reclamation), began a study in 2008 to develop a numerical model to simulate groundwater and surface-water interactions in the Carson River basin upstream of Lahontan Dam and downstream of Carson Valley. Hydrogeologic information was compiled and collection of hydrogeologic data began as a basis for developing the framework for a numerical groundwater flow model. Concurrently, work began on development of precipitationrunoff models of selected watersheds in the middle Carson River basin to estimate runoff and groundwater recharge from the watersheds (Jeton, in press).

\section{Purpose and Scope}

This report presents and describes the hydrogeologic information from which a numerical model of the groundwater and surface-water systems in the middle Carson River basin is currently being developed. Maps of hydrogeologic units in the study area were compiled, along with maps showing the thickness of Tertiary rocks and sediments, the thickness of Quaternary basin-fill sediments (using existing gravity data and gravity measurements collected at 95 new stations), and the altitude of pre-Cenozoic rocks compared with regional water-level altitudes. Estimates of the distribution of aquifer properties were made using slug-test data collected at 30 wells from 2009 to 2010 in Dayton and Churchill Valleys, aquifer-test data compiled and analyzed for 16 wells in Dayton Valley, information from driller's logs, and ranges of specific yield reported in the literature. Water levels measured at about 300 wells in April 2009, including 10 wells installed for this study, were used to update previously compiled water-level altitude maps for each valley and to evaluate long-term waterlevel changes and regional groundwater- flow directions. Information on groundwater and surface-water interactions was gained by analysis of streamflow measurements and water samples collected at 13 sites in Dayton and Churchill Valleys from 2007 to 2009, and from comparisons of waterlevel fluctuations measured in 13 wells to changes in the stage of the Carson River from 2007 to 2009 and to changes in the levels of Lahontan Reservoir from 2005 to 2009.

\section{Geographic Setting}

The middle Carson River basin extends a distance of about $60 \mathrm{mi}$ in west-central Nevada and covers an area of about $900 \mathrm{mi}^{2}$ (fig. 1). The headwaters of the Carson River lie at altitudes above 10,000 ft in the Sierra Nevada of east-central California, and the East and West Forks enter the southern end of Carson Valley. Through Carson Valley, the flow of the East and West Forks is diverted through a 


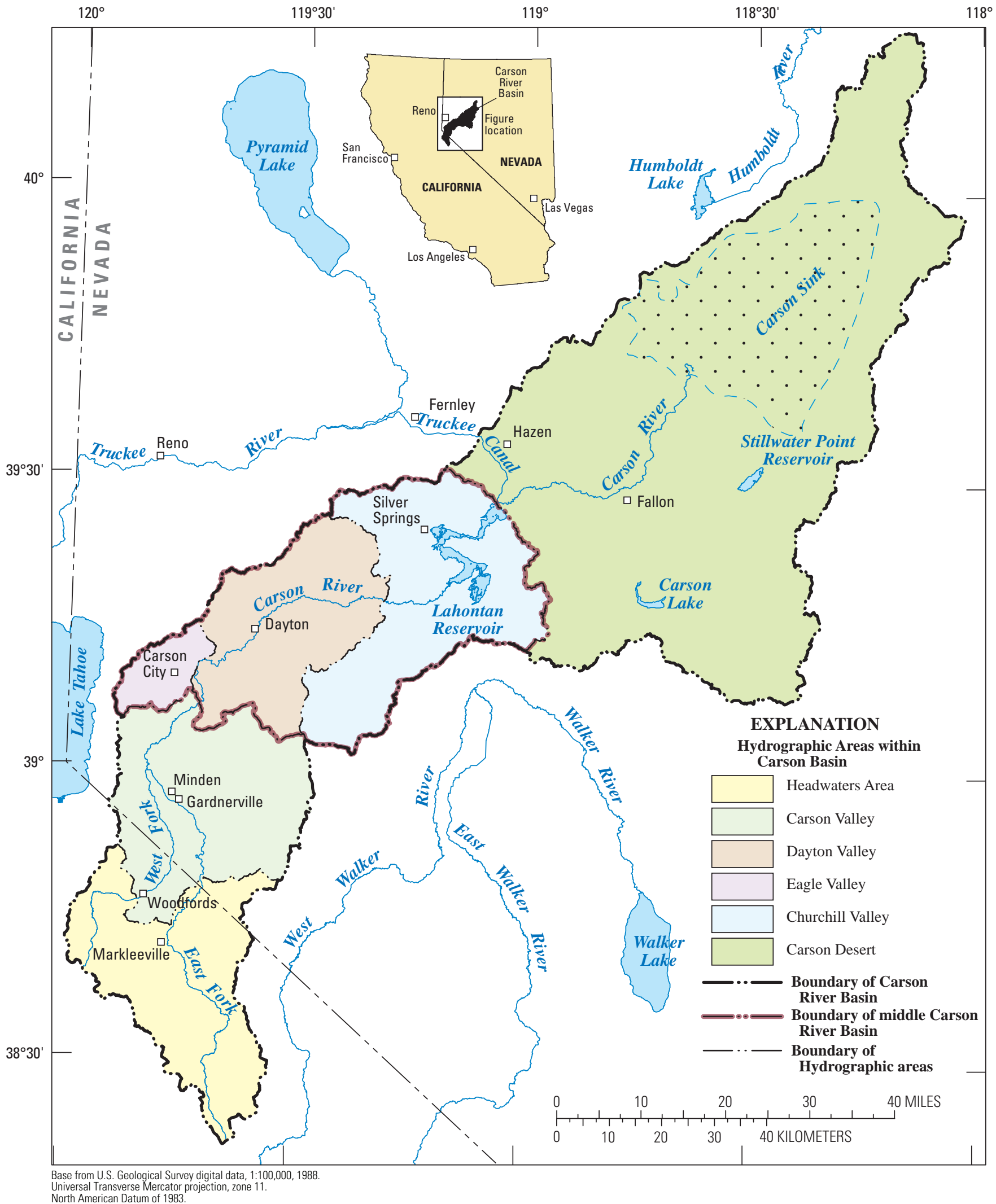

Figure 1. Location of the Carson River basin, hydrographic areas within the basin, and selected geographic features, Nevada and California. 
complex network of canals and ditches for flood irrigation of about 39,000 acres of mainly pasture grasses and alfalfa (Maurer and Berger, 2007, p. 44). The East and West Forks join northwest of Minden, Nevada, and the mainstem of the Carson River flows out of Carson Valley a few miles southeast of Carson City, into the westernmost part of the Dayton Valley hydrographic area (fig. 2A). Maurer (1997) divided the Dayton Valley hydrographic area into five subbasins, from west to east: Riverview, Moundhouse, Carson Plains, Bull Canyon, and Stagecoach (fig. 2A). The Carson Plains subbasin is often called Dayton Valley locally, however, there is not a single valley named "Dayton Valley", only the hydrographic area.

The Carson River flows along the eastern side of Eagle Valley in the Riverview subbasin of the Dayton Valley hydrographic area, and through a canyon in the Moundhouse subbasin upstream of Dayton, Nevada. The flow of the Carson River is diverted for flood irrigation of agricultural fields on a narrow flood plain extending about $0.5 \mathrm{mi}$ on each side of the river and incised about $50 \mathrm{ft}$ into the valley floor in the Carson Plains and Bull Canyon subbasins, and in Churchill Valley (fig. 2B). About 3,100 acres of pasture grasses and alfalfa were irrigated in 2006 in the Dayton Valley hydrographic area, and about 1,200 acres of pasture grasses and alfalfa were irrigated in 2007 in the Churchill Valley hydrographic area (Maurer and others, 2009, p. 34). The river flows through another canyon west of Table Mountain in the Bull Canyon subbasin and is separated from the Stagecoach subbasin by a low topographic divide between Table Mountain and Churchill Butte. The Carson River enters the Churchill Valley hydrographic area south of Churchill Butte near historic Fort Churchill, about $8 \mathrm{mi}$ south of Silver Springs, Nevada, and enters Lahontan Reservoir about $8 \mathrm{mi}$ downstream of the boundary of the Churchill Valley hydrographic area. The term "hydrographic area" was included in this discussion to familiarize the reader with their locations. In the remainder of this report, the hydrographic areas will be referred to using only the name of the valley they represent.

A topographic divide is not present between northernmost Mason Valley and the Carson River basin. Small wetlands near the northern end of Mason Valley drain northward through Adrian Valley, which is tributary to the Carson River southeast of Churchill Butte; however, surface-water inflow to the Carson River through Adrian Valley is largely ephemeral. A low topographic divide separates the northernmost end of Mason Valley from the Walker River. The Walker River is thought to have flowed periodically through Adrian Valley into the Carson River basin during the Holocene Epoch $(10,000$ years ago to the present), most recently from 1,500 to 1,000 and 500 to 300 years ago (Adams, 2007).

Annual flow of the Carson River is extremely variable, ranging from a low of about 26,000 acre-ft in 1977, to slightly more than 800,000 acre-ft in 1983 near Fort Churchill (Maurer and others, 2009, p. 41). The Carson River itself becomes ephemeral in the middle Carson River basin during dry years, and some reaches of the river channel may be dry downstream from the eastern side of the Riverview subbasin.
Lahontan Reservoir, constructed from 1903 to 1915, stores water for the Newlands Project, one of the first reclamation projects in the United States. The reservoir also receives water from the Truckee River through the Truckee Canal (figs. 1 and $\underline{2 B}$ ). Releases from Lahontan Reservoir provide water for irrigation of about 56,000 acres downstream in Lahontan Valley, which is encompassed by the Carson Desert hydrographic area. Flow not used for irrigation provides water for wetlands on the eastern and southern sides of Lahontan Valley, and any remaining flow enters the Carson Sink about 15 mi north of Fallon, Nevada (ig. 1). Lahontan Reservoir is the only large reservoir on the Carson River, in contrast to the adjacent Truckee and Walker River basins, both of which have several large reservoirs in their upstream reaches.

Most of the Carson River basin lies in the rain shadow of the Sierra Nevada, with precipitation decreasing abruptly from about $33 \mathrm{in} / \mathrm{yr}$ at the crest of the Carson Range to about $10 \mathrm{in} /$ yr on the floor of Eagle Valley (period of record 1971-2000, Maurer and Halford, 2004, p. 26). Precipitation over the eastern part of the basin ranges from $14 \mathrm{in} / \mathrm{yr}$ at Virginia City, Nevada, in the western part of the Virginia Range, to only 5 in/ yr at Lahontan Dam (period of record 1971-2000; National Oceanic and Atmospheric Administration, 2002, p. 12).

Streamflow tributary to the Carson River is perennial in three watersheds in Eagle Valley: Clear Creek, and Ash Canyon and Kings Canyon Creeks (fig. 2A). Flow from Clear Creek enters the northern part of Carson Valley to join the Carson River. Flow from Ash Canyon and Kings Canyon Creeks has been increasingly diverted for municipal supply in Carson City, and flow reaches the Carson River in the Riverview subbasin of Dayton Valley only during spring runoff in wet years and floods. Eagle Valley Creek drains the eastern side of Eagle Valley and joins the Carson River in the Riverview subbasin. Tributary streamflow in the remaining part of the middle Carson River is largely ephemeral, with flow reaching the Carson River only during spring runoff in wet years and floods.

\section{Previous Hydrologic Investigations}

Previous hydrologic investigations are most numerous in Eagle Valley. The first hydrologic report for the valley (Worts and Malmberg, 1966) included water budget estimates and maps showing water-level altitude, depth to water, and the distribution of phreatophytes and irrigated land. In the mid-1970s and early 1980s, Arteaga and Durbin (1979) and Arteaga (1986) developed a numerical groundwater flow model of Eagle Valley using estimates of groundwater recharge and discharge, and estimates of aquifer thickness and hydrologic properties. In the late 1990s, Maurer and others (1996), Maurer and Berger (1997), and Maurer and Thodal (2000) made estimates of subsurface inflow of water to Eagle Valley from the surrounding watersheds and updated estimates of groundwater recharge. Schaefer and others (2007) 
A

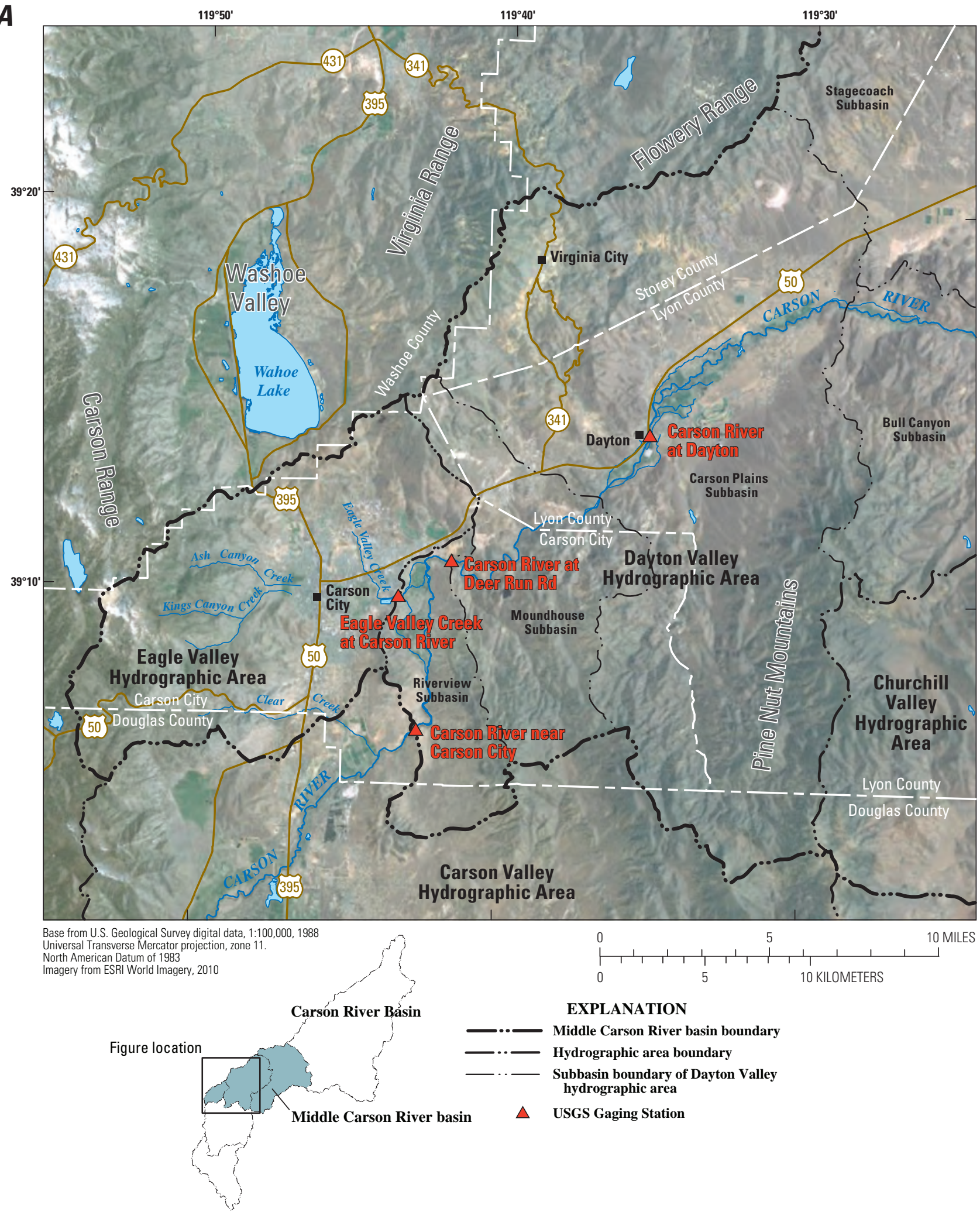

Figure 2. Selected geographic features of the middle Carson River basin, Nevada. (A) Eagle and Dayton Valleys, and (B) Churchill and western Lahontan Valleys. 


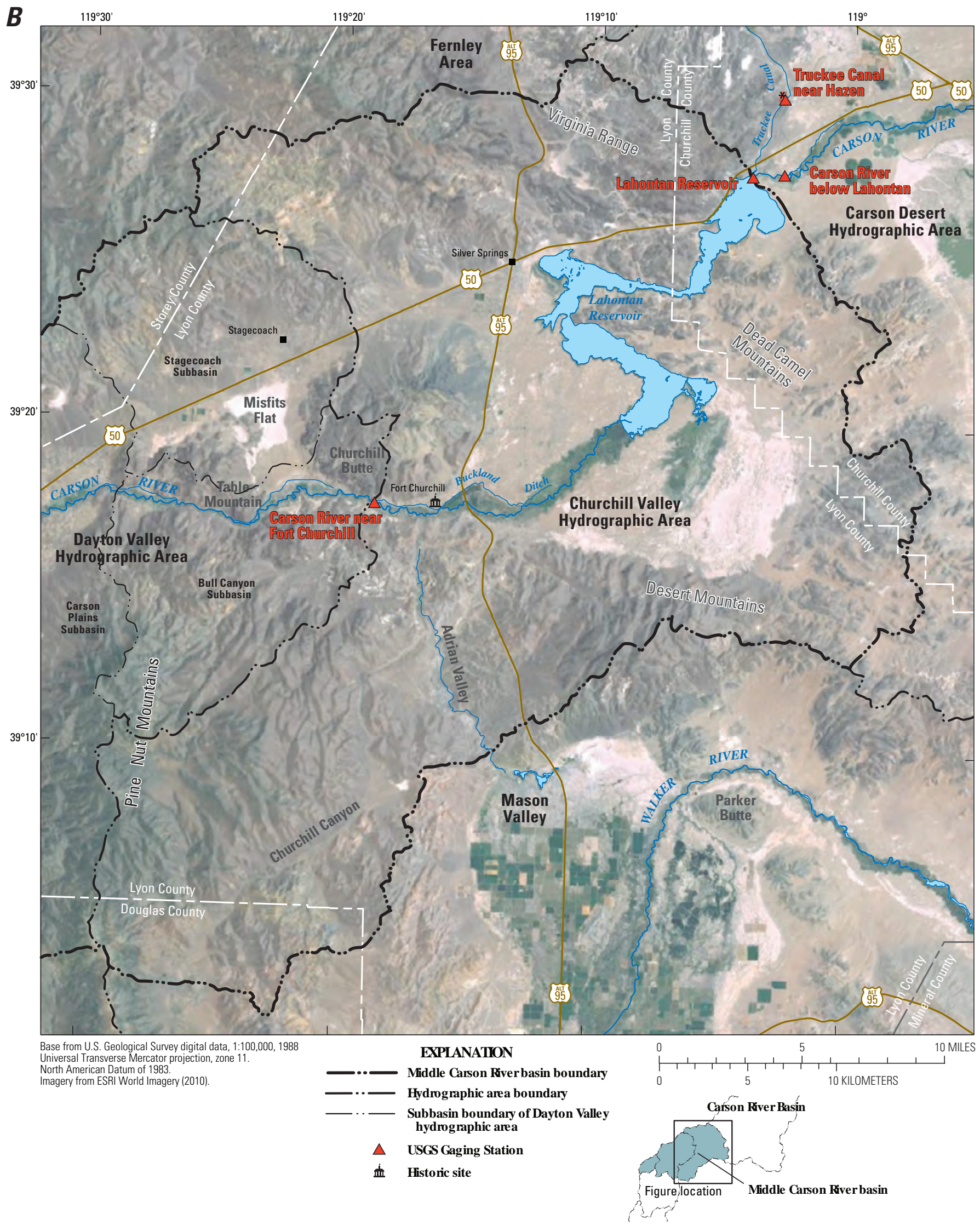

Figure 2.-Continued. 
modified the model developed by Arteaga (1986) to estimate the location of areas contributing recharge to public-supply wells. Maurer and others (2009) summarized information on tributary streamflow, water-level fluctuations, and groundwater pumping and flow directions in Eagle Valley.

Glancy and Katzer (1976) published the first estimates of water-budget components and maps showing the distribution of phreatophytes and irrigated land for Dayton and Churchill Valleys. Harrill and Preissler (1994) developed a numerical groundwater flow model for the Stagecoach subbasin and westernmost Churchill Valley. Their work provided estimates of groundwater recharge and discharge, maps showing the depth to water and water-level altitude for pre-development conditions in 1971 and spring of 1982, and maps showing the distribution of aquifer thickness and hydrologic properties. Schaefer and Whitney (1992) developed geophysical models showing estimated depth to bedrock along a cross section in the Carson Plains subbasin, and maps showing the depth to water, water-level altitude, and groundwater flow directions for 1982 in the Carson Plains and Stagecoach subbasins. Maurer (1997) made estimates of water-budget components for the Dayton Valley subbasins and mapped water-level altitudes and groundwater flow directions in 1995 for the Riverview, Moundhouse, and Carson Plains subbasins. Maurer and others (2009) summarized information on tributary streamflow, water-level fluctuations, groundwater pumping and flow directions, changes in land use from the 1970s to 2005, and gains to and losses from the Carson River for Dayton Valley as a whole and for each subbasin.

Churchill Valley is the least studied in the middle Carson River basin. The geophysical models of Schaefer and Whitney (1992) showed estimated depth to bedrock along two cross sections in Churchill Valley, and maps showing the depth to water, water-level altitude, and groundwater-flow directions for 1982. Brown and Caldwell (2004) summarized existing hydrologic data in an evaluation of groundwater conditions. Maurer and others (2009, p. 60-61 and 83) estimated water losses from the Carson River through Churchill Valley, and provided water-level data showing how infiltration losses from Lahontan Reservoir to the groundwater system varies with changing stage in the reservoir.

\section{Geologic Framework}

Geologic features of the middle Carson River basin that, in part, control groundwater flow include the types of rocks and sediments through which flow takes place, their thickness and hydraulic properties, and the geologic history and structural setting of the area. Maps were compiled and developed for this study that show the surficial exposures of hydrogeologic units and faults of Quaternary age, the extent of ancient Lake Lahontan from early to late Pleistocene, the thickness of rocks and sediments of Tertiary and Quaternary age, the altitude of rocks of pre-Cenozoic age, and the thickness of basin-fill sediments of Quaternary age in each valley. Delineation of these geologic features provides information needed for the development of a numerical model.

\section{Hydrogeologic Units and Geologic History}

Geologic units in the middle Carson River basin mapped mostly by Stewart (1999a) at a scale of 1:100,000 were grouped into hydrogeologic units assumed to have similar hydraulic characteristics (fig. 3). Consolidated rocks of Tertiary to Triassic age were grouped into granitic and metamorphic hydrogeologic units, and consolidated volcanic rocks of Tertiary age were grouped into ashflow tuffs, andesitic, basaltic and rhyolitic, and semiconsolidated sedimentary hydrogeologic units. Various types of unconsolidated sediments of Quaternary age were grouped into a basin-fill hydrogeologic unit. Because the map published by Stewart (1999a) does not extend to the eastern side of the study area, a map developed by Maurer and others (2004) and having similar hydrogeologic units was used in this study for the easternmost 4-5 mi of the study area. The hydrogeologic map of Maurer and others (2004) was based on a 1:500,000-scale geologic map for the entire State of Nevada compiled by Stewart and Carlson (1978). Differences in the boundaries of the hydrogeologic units on the two maps are apparent along a north-south line on the eastern side of the study area. Resolving the differences in the mapped extent of hydrogeologic units along the boundary of the two maps was beyond the scope of this study, and the differences were not considered critical for the purposes of this report.

The hydrogeologic units consisting of consolidated rocks are much less permeable to groundwater flow than the basinfill unit. However, fractured zones within the consolidated rocks likely provide sufficient permeability to supply smallproducing wells (see wells with water strata in consolidated rocks, appendix A). Numerous domestic wells have been completed in the Tertiary volcanic rocks near the periphery of the valleys, most notably in the Stagecoach subbasin and in Churchill Valley. Granitic and metamorphic rocks were grouped separately because Maurer and Berger (1997, p. 11) showed that metamorphic rocks generally were less permeable than granitic rocks surrounding Eagle Valley. Maurer and others (2004, p. 7) showed that basaltic and rhyolitic rocks and ash-flow tuffs generally were more permeable than andesitic rocks in Nevada. In this report, rhyolitic rocks were grouped with basaltic rocks because of their similar permeability (Maurer and others, 2004, p. 7) and the minor extent of outcrops of rhyolitic rocks in the study area. Ash-flow tuffs were grouped separately from the other volcanic rocks because of their exposure near the Moundhouse subbasin, where they may be important in controlling groundwater flow. 


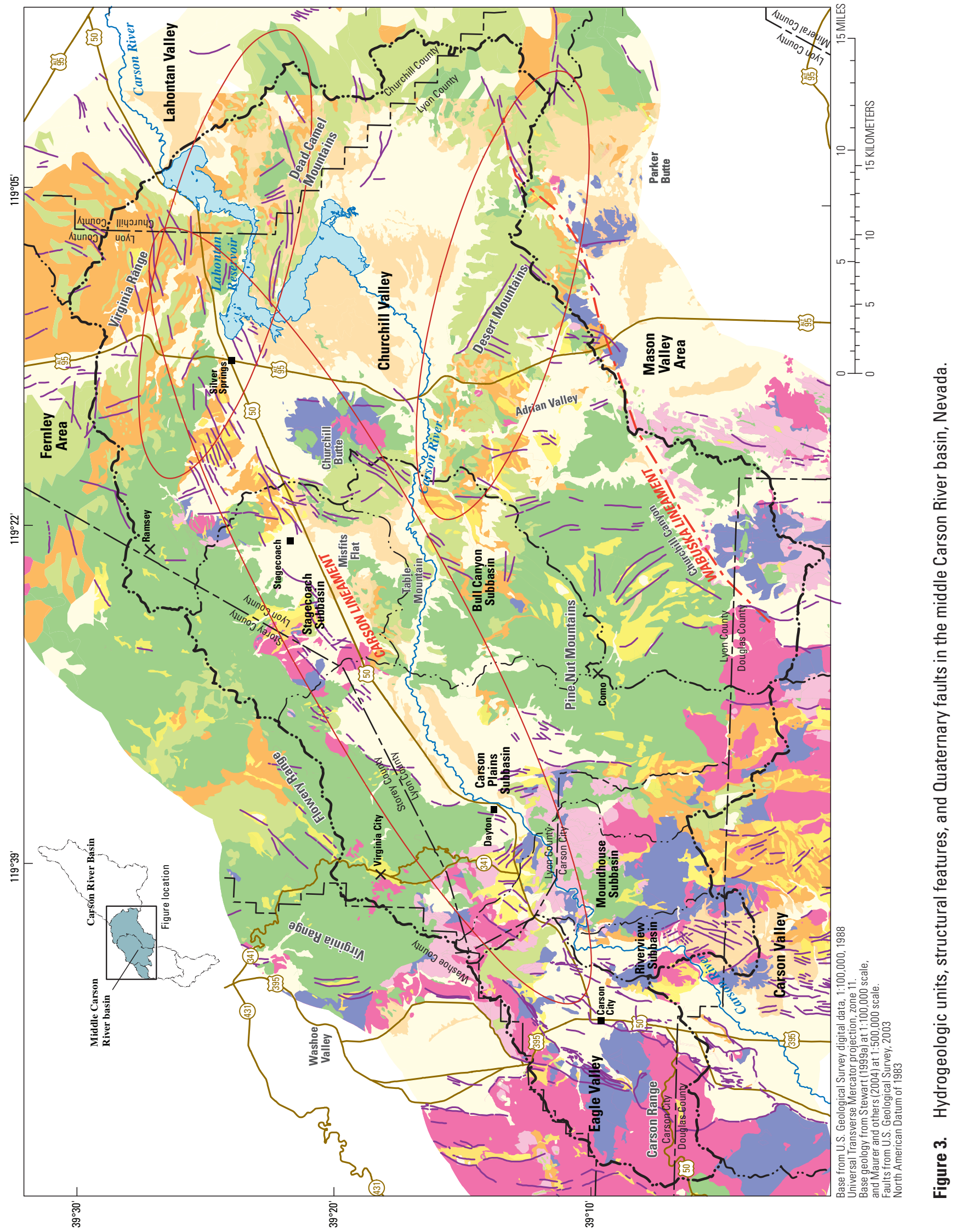




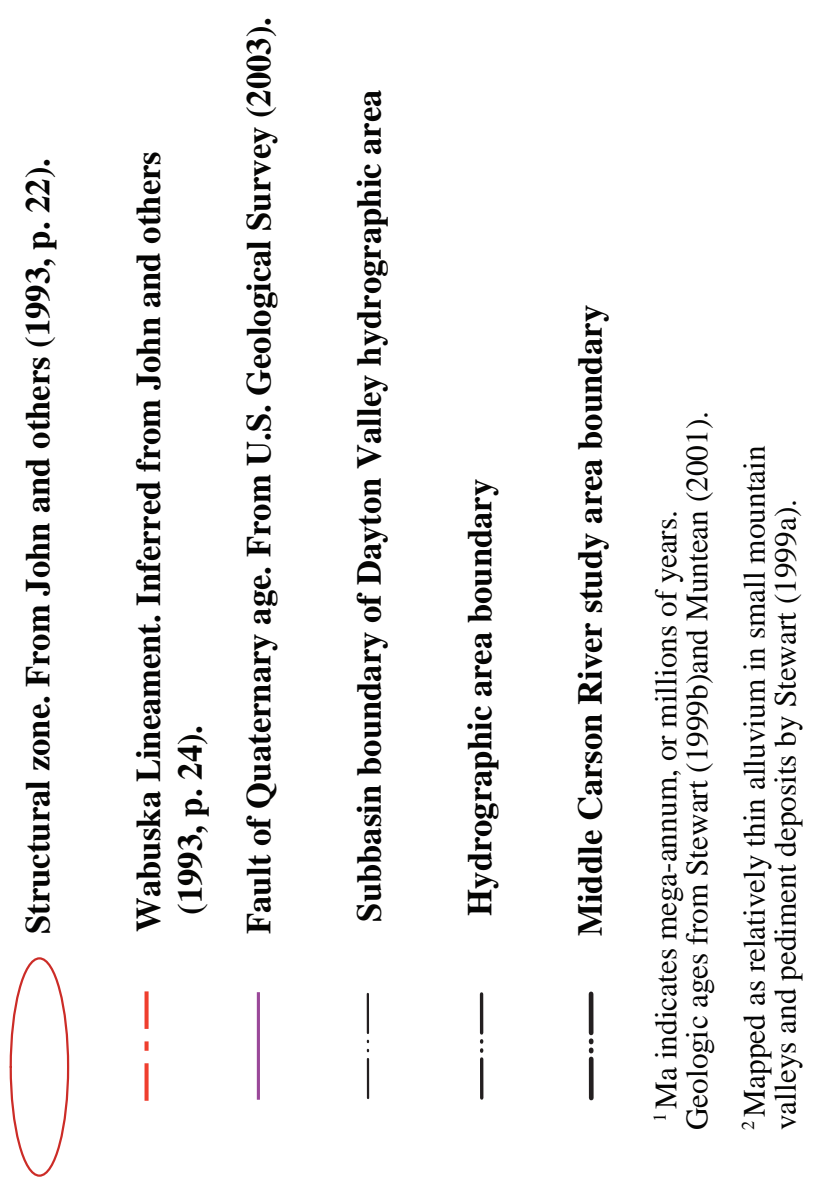

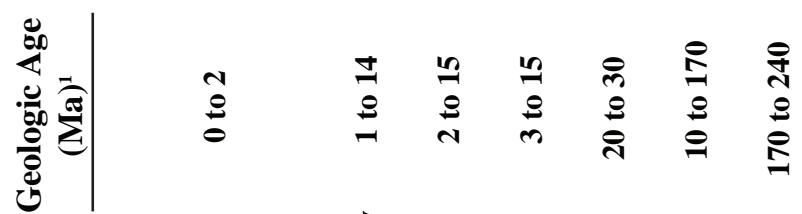

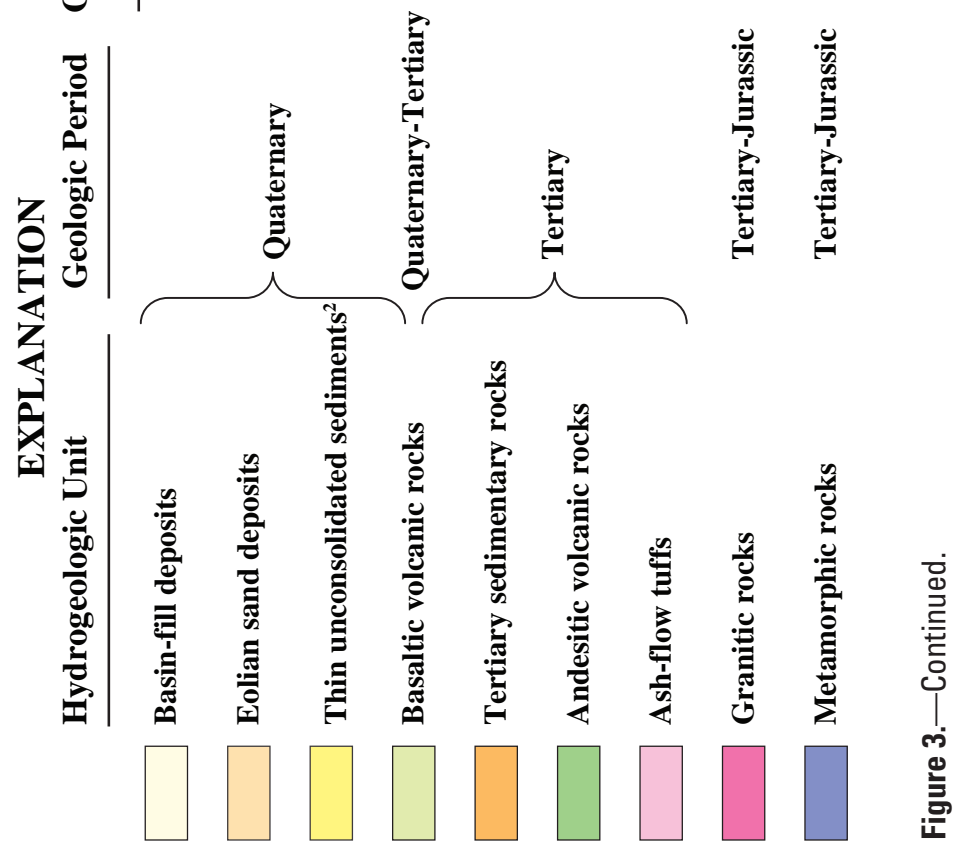


The Tertiary sedimentary hydrogeologic unit also is likely to be less permeable than the basin-fill unit (Maurer and others, 2004, p. 7). However, domestic wells have been installed that likely withdraw groundwater from the unit. Tertiary sediments were grouped separately from unconsolidated Quaternary sediments because they are often fine-grained and are described as shale, siltstone, sandstone, or conglomerate with varying degrees of consolidation (Moore, 1969, p. 12; Pease, 1980, p. 14).

Granitic and metamorphic hydrogeologic rock units generally are exposed near each other and constitute most of the bedrock surrounding Eagle Valley, where they underlie Quaternary-age basin-fill sediments (fig. 3). Similarly, the granitic and metamorphic rock border most of the Riverview subbasin and are exposed in the northern part of the Moundhouse subbasin, between the Carson Plains and Stagecoach subbasins, on the eastern side of Churchill Butte, and along the southern part of the Desert Mountains. In the eastern part of the study area, the granitic and metamorphic rocks underlie the Tertiary-age hydrogeologic units. The granitic and metamorphic rocks were grouped together and called pre-Cenozoic rocks for the purposes of estimating the thickness of overlying Tertiary-age volcanic rocks and sediments and Quaternary-age basin-fill sediments.

The metamorphic rock hydrogeologic units are of Triassic to Jurassic age, range in age from about 170 to 240 mega-annum (Ma, million years; Stewart, 1999b, p. 9-10), and consist of volcanic and sedimentary rocks that were metamorphosed by heat and pressure during intrusion of granitic rocks from 80 to $110 \mathrm{Ma}$ (Stewart, 1999b, p. 8). Moore (1969, p. 7) describes some of the volcanic portions of the unit as massive and structureless. Maurer and Berger (1997, p. 11) estimated hydraulic conductivities of the metamorphic rocks in Eagle Valley ranging from $0.1 \mathrm{ft} / \mathrm{d}$ where weathered to clay, to $30 \mathrm{ft} / \mathrm{d}$ where the rocks are fractured. The aggregate thickness of the metamorphic rock hydrogeologic unit is estimated to be $24,000 \mathrm{ft}$ (Moore, 1969, p. 6).

The granitic hydrogeologic units are primarily Cretaceous in age, ranging from about $170 \mathrm{Ma}$ along the southern boundary of the study area in the Pine Nut Mountains, to 110 to $80 \mathrm{Ma}$ in the Carson Range, where they are part of the Sierra Nevada batholith (Moore, 1969, p. 8; Stewart, 1999b, p. 8-9). The thickness of the granitic rock unit has not been reported but is likely thousands of feet. Maurer and Berger (1997, p. 11) estimated that hydraulic conductivities of the uppermost 30-40 ft of weathered and decomposed granitic rocks range from 0.4 to $5 \mathrm{ft} / \mathrm{d}$ in the Clear Creek drainage of Eagle Valley.

Following emplacement of the Sierra Nevada batholith, volcanism during the Tertiary period produced extensive and thick sections of three types of volcanic rocks that have been recognized over large parts of the western United States (John and others, 1993, p. 15). Volcanism from 30 to $20 \mathrm{Ma}$, related to a shallow dipping subduction zone beneath the Western United States, was accompanied by widespread eruption of volcanic rocks that form the ash-flow tuff hydrogeologic unit. Subsequently, a period of volcanism associated with renewed high-angle subduction along the continental margin and early development of the Cascade volcanic belt took place from about 20 to $12 \mathrm{Ma}$, producing the oldest rocks in the andesitic hydrogeologic unit (John and others, 1993, p. 17). Extension of the Earth's crust beginning about 16 Ma produced broad basins in which the Tertiary sedimentary unit was deposited, and initiated eruption of basaltic rocks that form the basaltic hydrogeologic unit (John and others, 1993, p. 19). Faulting that produced the present-day topography began about $6 \mathrm{Ma}$ and also is the result of crustal extension (John and others, 1993, p. 23).

The ash-flow tuff hydrologic unit forms the base and oldest part of the Tertiary-age section of rocks and sediments, ranging in age from about 30 to $20 \mathrm{Ma}$ (Stewart, 1999b, p. 7-8). The unit includes tuffs assigned separate names by Stewart (1999a) including Santiago Canyon, Eureka Canyon, Nine Hill, Lenihan Canyon, and Mickey Pass tuffs. The ash-flow tuffs often lie directly on the older granitic and metamorphic rocks (Moore, 1969, p. 10). The tuffs commonly crop out near exposures of the granitic and metamorphic units in the Moundhouse subbasin, the westernmost Carson Plains subbasin, and between the middle Carson River basin and Mason Valley (fig. 3). Moore (1969, p. 10) describes them as crystal tuffs, tuff breccias, and welded tuffs that have developed two sets of intersecting partings to form crude columns. The ash-flow tuff unit is reported to range in thickness from 1,000 ft near Virginia City to 4,000 ft near Yerington in Mason Valley (Moore, 1969, p. 10). The tuffs erupted and were deposited over a large area in northwestern Nevada (John and others, 1993, p. 17). Henry and Faulds (2010) showed that the tuffs originated from calderas in central Nevada and flowed westward through large "paleovalleys", valleys that pre-date the present-day valleys. Two paleovalleys, one along the Virginia Range, and one trending northwest through the Pine Nut Mountains, joined near the northern boundary of Eagle Valley and continued westward across Lake Tahoe (before the Lake Tahoe basin was formed) toward the central valley of California (Henry and Faulds, 2010, p. 341).

The andesitic volcanic rock hydrogeologic unit, which covers large parts of the middle Carson River basin, ranges in age from about 15 to $3 \mathrm{Ma}$ (Stewart, 1999b, p. 5). The unit includes two andesitic rock formations named in previous geologic reports as the Kate Peak and Alta Formations (Stewart, 1999b, p. 5). The unit is composed of crudely bedded or unbedded coarse breccias, flow breccias, and lava flows that are thought to have erupted from large, composite volcanoes near Virginia City, Como, and Ramsey (fig. 3; Moore, 1969, p. 11; John and others, 1993, p. 19). The thickness of the Alta Formation is as great as 2,700 ft near 
Virginia City (John and others, 1993, p. 17). The thickness of the andesitic volcanic rock unit was reported by Moore (1969, p. 11) to be several thousand feet thick in the southern Pine Nut Mountains, and he notes that the unit is associated with thick sections of the Tertiary sedimentary unit. Moore also reported that the andesitic volcanic rock unit is overlain by the Tertiary sedimentary unit in the southern Pine Nut Mountains and overlies the Tertiary sedimentary unit in the Desert Mountains. John and others (1993, p. 19) reported that near Virginia City, the Kate Peak Formation includes almost 3,000 ft of the Tertiary sedimentary unit.

The Tertiary sedimentary hydrogeologic unit, which ranges in age from about 15 to $2 \mathrm{Ma}$ (Muntean, 2001, p. 5; Stewart, 1999b, p. 5), is exposed primarily in the Bull Canyon subbasin, near the divide between the Stagecoach subbasin and Churchill Valley, and surrounding Churchill Valley. The unit has been previously mapped in and nearby the study area as the Sunrise Pass, Coal Valley, and Truckee Formations (Stewart, 1999b, p. 6; Muntean, 2001, p. 7). The Tertiary sediments generally overlie and intertongue with the andesitic unit and are overlain by and intertongue with the basaltic volcanic rock unit (Stewart 1999b, p. 6). The unit is characterized by abrupt lithologic changes and includes tuffaceous sandstone, siltstone, shale, diatomite, conglomerate, and volcanic breccias deposited in basins formed by the eruption of the andesitic rocks (Moore, 1969, p. 12; John and others, 1993, p. 19; Stewart, 1999b, p. 5-7). The Tertiary sediments generally are semi-consolidated and partly cemented. The thickness of the Tertiary sedimentary unit is reported to range from more than 3,000 ft near Virginia City to more than $1,000 \mathrm{ft}$ in the Pine Nut Mountains (Moore, 1969, p. 12). The Tertiary sedimentary rocks make up the hydrogeologic unit most susceptible to erosion; it is typically reduced to areas of low relief in the study area and commonly capped with a layer of gravels (Moore, 1969, p. 12).

The basaltic volcanic rock hydrogeologic unit is exposed near Carson City, along the southern boundary of the Stagecoach subbasin, in the Bull Canyon subbasin near the Carson River, on the western side of Churchill Butte, and extensively surrounding Churchill Valley. The unit ranges in age from about 14 to $1 \mathrm{Ma}$ (Stewart, 1999b, p. 4, 6) and represents the last period of volcanic activity in the study area (Moore, 1969, p. 14). As mapped for this study, the unit includes small isolated exposures of Quaternary- and Tertiaryage rhyolite, and is reported to include minor amounts of andesitic rocks (Moore, 1969, p. 14; John and others, 1993, p. 19). The oldest part of the unit includes rocks mapped as the Pyramid sequence, which may be as thick as 1,000 $\mathrm{ft}$ (John and others, 1993, p. 19). Maurer and Berger (1997, p. 11) estimated a hydraulic conductivity of only $3 \mathrm{ft} / \mathrm{d}$ for basaltic rocks, but from 300 to $500 \mathrm{ft} / \mathrm{d}$ for a cobble zone encountered within the basaltic rocks in Eagle Valley. Maurer and Welch (2001, p. 25) estimated the hydraulic conductivity of a basalt aquifer near Fallon to range from 500 to more than 1,000 ft/d. The basalt aquifer near Fallon consists of fractured, vesicular basalt flows alternating with more massive flows over a total thickness of about $300 \mathrm{ft}$ (Maurer, 2002). Basalt outcrops in the Stagecoach and Bull Canyon subbasins and in Churchill Valley also are quite vesicular and fractured, based on field inspection, and may have hydraulic conductivities similar to those of the Fallon basalt aquifer.

The basin-fill hydrogeologic unit overlies the other hydrogeologic units and forms the principal aquifers in the study area. The basin-fill hydrogeologic unit fills the center of each valley and comprises unconsolidated sediments deposited by streams forming alluvial fans surrounding the valleys, fluvial sediments deposited by the Carson River and other, smaller streams, and lake sediments deposited during high stands of ancient Lake Lahontan. The sediments, ranging in age from 1.6 Ma to recent, were estimated to be more than 2,000 ft thick in Eagle Valley, and more than 3,000 ft thick in the Stagecoach subbasin (Arteaga, 1986, p. 26; Harrill and Preissler, 1994, p. 13; see section, “Thickness of Quaternary Basin-Fill Sediments” for new estimates of thickness).

Sediments deposited by ancient Lake Lahontan are present in the basin-fill hydrogeologic unit from the Moundhouse subbasin downstream to Lahontan Valley. Ancient Lake Lahontan covered much of northwestern Nevada several times during the Pleistocene epoch, and its level varied in response to changing glacial climates (Morrison, 1964, p. 110). High stands of the lake extended from about 1 Ma to $850 \mathrm{ka}$ (thousand years), 650 to $600 \mathrm{ka}, 400$ to $130 \mathrm{ka}$, and 25 to 10 ka (Benson and others, 1990, p. 241; Benson, 1991, p. 115; Morrison, 1991, p. 292). The highest stands, at an altitude of about 4,360 ft (1,330 m), were reached during 650 to $600 \mathrm{ka}$, and during late Pleistocene (13,500 ka; Benson and Thompson, 1987, p. 78; Morrison, 1991, p. 292). Reheis (1999) published a map showing that lake levels in early to middle Pleistocene may have reached 4,590 ft (1,400 m), about $200 \mathrm{ft}$ higher than during the late Pleistocene, and the lake extended westward into the Moundhouse subbasin (fig. 4). At the high stand of the lake mapped by Reheis (1999), ancient Lake Lahontan was greater than $400 \mathrm{ft}$ deep in the southeastern part of Churchill Valley, $300 \mathrm{ft}$ deep in the Stagecoach subbasin, and about $250 \mathrm{ft}$ deep in the center of the Carson Plains subbasin. Between high lake stands were periods, lasting from about 95,000 to 250,000 years, when the lake was either dry or very shallow (Morrison, 1991, p. 291). During high lake stands in late Pleistocene, the Walker River basin was connected to the Carson River basin through Adrian Valley (fig. 4), and evidence discussed by Benson and Thompson (1987, p. 82) shows that the Walker River periodically was diverted through Adrian Valley into the Carson River basin. Adams (2007, p. 126) notes that the Walker River flowed most recently into the Carson River basin from 1,500 to 1,000 and 500 to 300 years before present. 


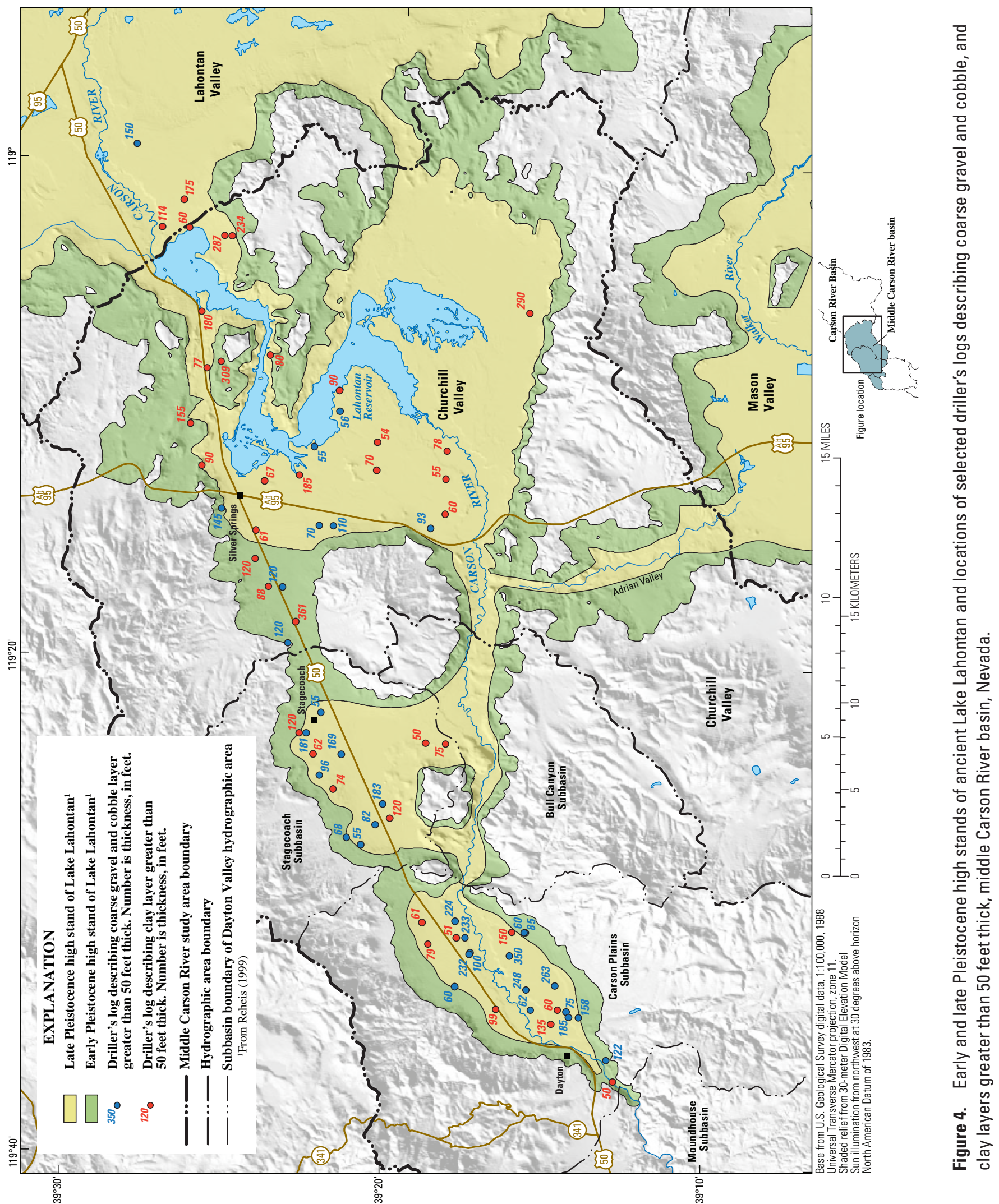


The sediments deposited in Lake Lahontan vary greatly in lithology. During high lake stands, sediments deposited by the Carson River likely formed deltas in the Carson Plains subbasin, well-sorted sand and gravel beaches and bars were formed by wave action along the shoreline, and silt and clay were deposited in the deeper parts of the lake. During periods when the lake was dry, the Carson River meandered across the valley floors, and eolian (wind-blown) sand deposits likely covered much of the valley floors in the middle Carson River basin as described by Morrison (1964, p. 102-103) in Lahontan Valley and as mapped by Stewart (fig. 3; 1999b). As the level of ancient Lake Lahontan rose and fell, the deposition of deltaic sediments at the mouth of the Carson River moved upstream and downstream, and the deposition of beach sand and gravel, deep-lake silt and clay, and eolian sand progressed laterally across the valley floors, creating a complex mixture of Quaternary sediments within the basin-fill hydrogeologic unit. The locations of driller's logs that describe layers of coarse gravel and cobbles and layers of clay greater than $50 \mathrm{ft}$ thick are shown in figure 4 . The logs were selected from the well-log database maintained by the Nevada Division of Water Resources (http://water.nv.gov/Engineering/wlog/ wlog.cfm) and well locations were checked with parcel maps to ensure correct location.

Coarse gravel and cobble layers are greater than $300 \mathrm{ft}$ thick and as deep as $600 \mathrm{ft}$ below land surface in the Carson Plains and Stagecoach subbasins, and some wells penetrate more than one thick gravel or cobble layer (appendix B). Thick clay layers also are found in the Carson Plains and Stagecoach subbasins, sometimes in proximity to wells that were drilled through thick gravel layers, and sometimes in the same well that also penetrated thick gravel layers. The drilling logs for many wells in Churchill and western Lahontan Valleys report the presence of thick clay layers.

Some unconsolidated sedimentary units mapped by Stewart (1999a) are relatively thin where mapped near and within the mountain blocks and on the valley floor. These units do not form important aquifers and most likely lie above the water table. They are described by Stewart $(1999 b$, p. 1,4$)$ as alluvium in small mountain valleys in the mountain-block area east of Como, as veneers of eolian sand in the Dead Camel Mountains and on the valley floors throughout the study area, and as veneers of pediment deposits (poorly sorted gravel, sand, and silt) covering eroded benches of consolidated rock or Tertiary sediments throughout the study area. Because these thin deposits of unconsolidated sediments do not form important aquifers, they have been distinguished from the hydrogeologic unit of basin-fill deposits in figure 3 .

\section{Geologic Structure}

The post-depositional folding, tilting, and faulting of the rocks and sediments that make up the hydrogeologic units, collectively called their geologic structure, may be important in controlling groundwater flow. Detailed information on how faults may affect groundwater flow in the middle Carson River basin is lacking. Quaternary-age faults are shown in figure 3 to indicate locations where recent and most likely repeated movement may affect groundwater flow. Faulting in consolidated rocks can produce fractures along which secondary permeability, and thus paths of preferential groundwater flow, are created. Faulting in unconsolidated sediments may provide either avenues for groundwater flow or barriers to flow (Maurer and others, 2004, p. 11-13).

The study area lies near the western margin of the Basin and Range Province, which generally is characterized by north-south trending mountain ranges separated by intervening valleys, or basins. The topography of the Basin and Range Province is the result of crustal extension beginning about $6 \mathrm{Ma}$, in which the mountain ranges have been uplifted and the basins down-dropped along north-south trending normal faults.

The structure of the middle Carson River basin differs from that in most of the Basin and Range Province. Northsouth trending faults are present in Washoe, Eagle, Carson, and Mason Valleys, and in the southern parts of the Carson Plains subbasin and Churchill Valley (fig. 3). Most of the study area, however, lies in an area in which the north-south pattern of normal faulting has been disrupted by northeast trending, left-lateral, strike-slip faulting along the Carson Lineament (Stewart, 1988, p. 688; John and others, 1993, p. 25). The Carson Lineament is expressed as the alignment of the floors of Eagle Valley, the Carson Plains and Stagecoach subbasins, and the northern part of Churchill Valley; the long-axis of the Virginia Range; and numerous northeast-trending faults (see large oval, fig. 3; Rogers, 1975). The Carson River also follows the northeastern trend of the lineament. Moore (1969, p. 19) described the lineament as a structural and topographic "sag" that separates the northern part of the Pine Nut Mountains from the Virginia Range. Numerous northeast trending faults also are present along the topographic divide between Churchill and Mason Valleys, forming the Wabuska Lineament, or fault zone, about $15 \mathrm{mi}$ southeast and parallel to the Carson Lineament (Stewart, 1988, p. 687; John and others, 1993, p. 25).

The Carson Lineament was likely formed by the accommodation of movement along the Walker Lane belt, a northwest trending zone of right-lateral, strike-slip faulting that extends from Las Vegas to north of Pyramid Lake and disrupts the north-south trending faults of the Basin and Range Province. The Walker Lane belt encompasses the entire study area (Stewart, 1988), but Cashman and Fontaine (2000, p. 113) note that no known northwest trending faults associated with the Walker Lane belt are found adjacent to the Carson Lineament. The section of the Walker Lane belt near the Carson River basin was recognized as the Carson "block" by Stewart (1988, p. 688) and the Carson "domain" by Cashman and Fontaine (2000, p. 113), and is bounded on the south by the Wabuska lineament. Cashman and Fontaine (2000) and Surpless (2008) provide evidence of the clockwise rotation 
of structural blocks in the Carson River basin, bounded on the north and south by the Carson and Wabuska lineaments, respectively. The northeast-trending faults in the study area, the Carson Lineament, the Wabuska Lineament, and the clockwise rotation of structural blocks likely were formed in response to the right-lateral movement of the Earth's crust within the Walker Lane belt.

Two other structural zones of interest in the study area have been described by John and others (1993, p. 25) near the northern and southern parts of Churchill Valley (fig. 3). Near the northern part of the valley, a zone of east-southeast trending faults, rhyolitic, andesitic, and basaltic flows, and the east-southeast trend of the Dead Camel Mountains form the Lahontan Reservoir Structural and Volcanic Zone. Similarly, the Desert Mountains Structural and Volcanic Zone near the southern part of Churchill Valley is characterized by eastsoutheast trending faults and lava flows, and the east-southeast trend of the Desert Mountains. Moore (1969, p. 21) reported that exposures of pre-Tertiary rocks along the southern boundary of the Desert Mountains and that basaltic rocks down warped more on the north than the south side of the range suggests a northward tilt of the Desert Mountains. The abundance of young basaltic and andesitic rocks in the Desert Mountains and near the Lahontan Reservoir Structural and Volcanic Zone also suggests they were uplifted less and by more recent faulting than the other mountain ranges (Moore, 1969, p. 16, 21).

Moore (1969) reported other structural features in the study area that may be important in controlling groundwater flow. In Eagle Valley, granitic and metamorphic rocks of the Carson Range are cut by swarms of west-dipping normal faults, and the granitic rocks are deeply weathered to depths greater than $100 \mathrm{ft}$. The Pine Nut Mountains are actually composed of several blocks, bounded on the east by northtrending normal faults that have exposed the granitic and metamorphic basement rocks on the east, and tilted the blocks and the mountain range as a whole to the west (Moore, 1969, p. 18). Similarly, Churchill Butte is thought to be the exposed portion of a fault block tilted to the west, as shown by the exposure of granitic and metamorphic basement rocks its eastern side and the westward dip of andesitic and basaltic rocks on its western side (fig. 3; Moore, 1969, p. 21, 22). The exposure of granitic and metamorphic basement rocks on the southern side of the Virginia Range suggests that the range may be slightly tilted to the north (fig. 3; Moore, 1969, p. 21).

\section{Thickness of Tertiary and Quaternary Rocks and Sedimentary Units}

The development of a numerical groundwater flow model of the study area requires estimates of the thickness of the hydrogeologic units. To make such estimates, the hydrogeologic units were grouped into (1) those units comprising pre-Cenozoic rocks, mostly granitic and metamorphic rocks; (2) units comprising Tertiary volcanic (ash flow tuffs, andesites, and basalts) and sedimentary rocks; and (3) unconsolidated Quaternary basin-fill sediments. Variations in the thickness of the Tertiary and Quaternary units produce small variations in the gravity field of the Earth owing to differences in the density among the three groups. Measurements of the earth's gravity field at numerous locations provide data for estimates of their thickness (Telford and others, 1976, p. 7-30).

The thickness of the combined sections of Tertiary volcanic and sedimentary rocks and the Quaternary basin-fill deposits has been estimated by Ponce (2004) for northern Nevada using gravity data. The thickness was estimated for a $0.6 \mathrm{mi}(1-\mathrm{km})$ grid covering northern Nevada on the basis of data from more than 30,000 gravity stations and measurements of the physical properties of rocks from more than 480 locations (Ponce, 2004, p. 71, 72). For this study, the values for the grid cells were contoured using Geographic Information System (GIS) software. In the study area, the estimated thickness of Tertiary and Quaternary rocks and sediments ranges from zero where pre-Cenozoic rocks are exposed to more than 10,000 $\mathrm{ft}$ in the Bull Canyon subbasin, and more than 6,000 ft thick on the western side of Churchill Butte and beneath the Desert Mountains (fig. 5). At most locations in the study area, the estimated (contoured) thickness is zero or near zero in areas where pre-Cenozoic rocks are exposed, which suggests the dataset provides a reasonable estimate for the thickness of Tertiary and Quaternary rocks and sediments.

The altitude of the top of pre-Cenozoic rocks was estimated by subtracting the thickness of Tertiary and Quaternary rocks and sediments from the average altitude of land surface within each $0.6 \mathrm{mi}$ grid cell, using a 10-m digital elevation model (U.S. Geological Survey, 1999) and GIS software. The altitude of pre-Cenozoic rocks approximates the altitude of land surface where they are exposed, is as great as 4,000 ft below sea level in the Bull Canyon subbasin, and is 1,000-2,000 ft below sea level on the western side of Churchill Butte and beneath the Desert Mountains (ig. 6). Water-level altitudes shown in figure 6 are discussed in section, "Groundwater Levels and Regional Groundwater Flow." 


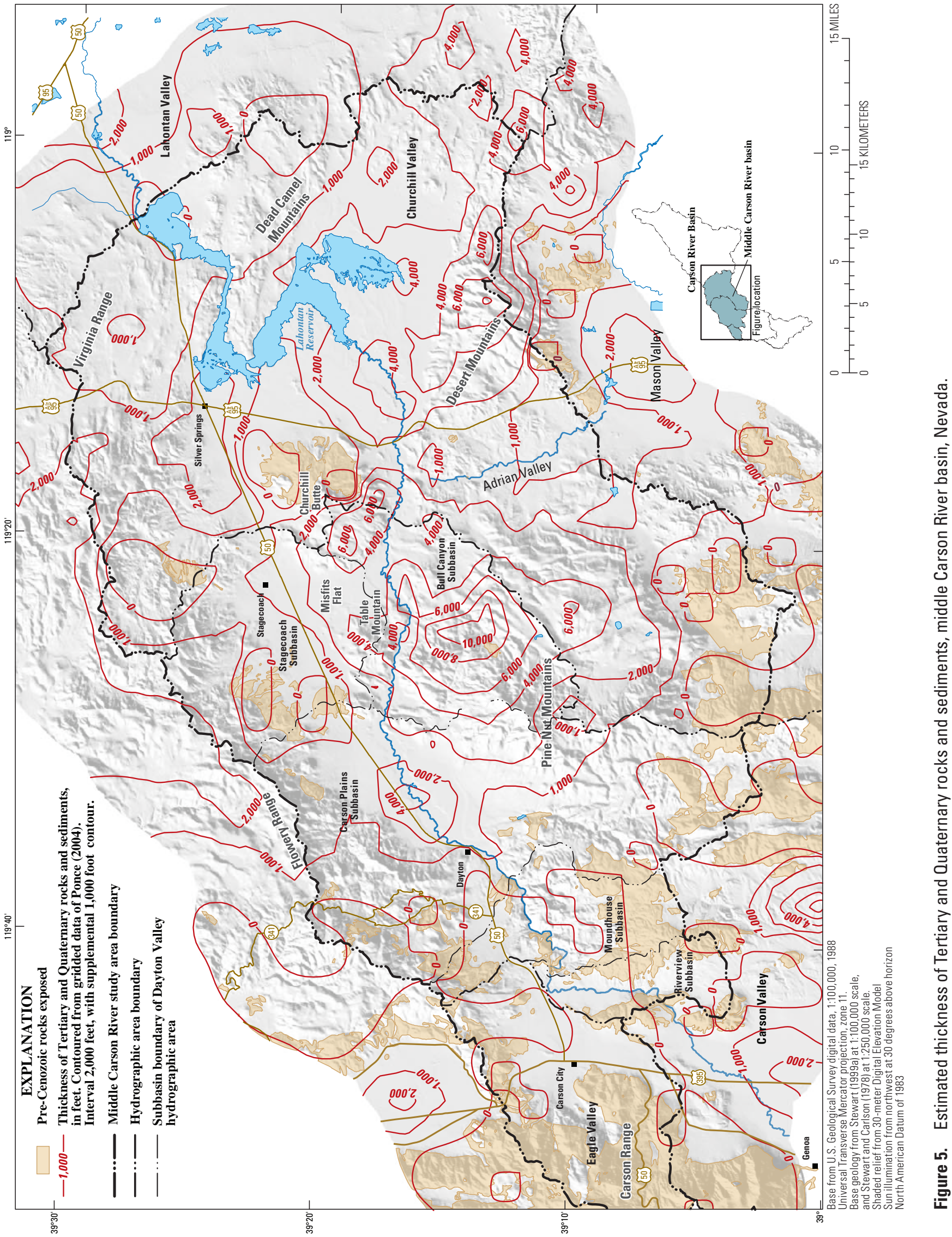




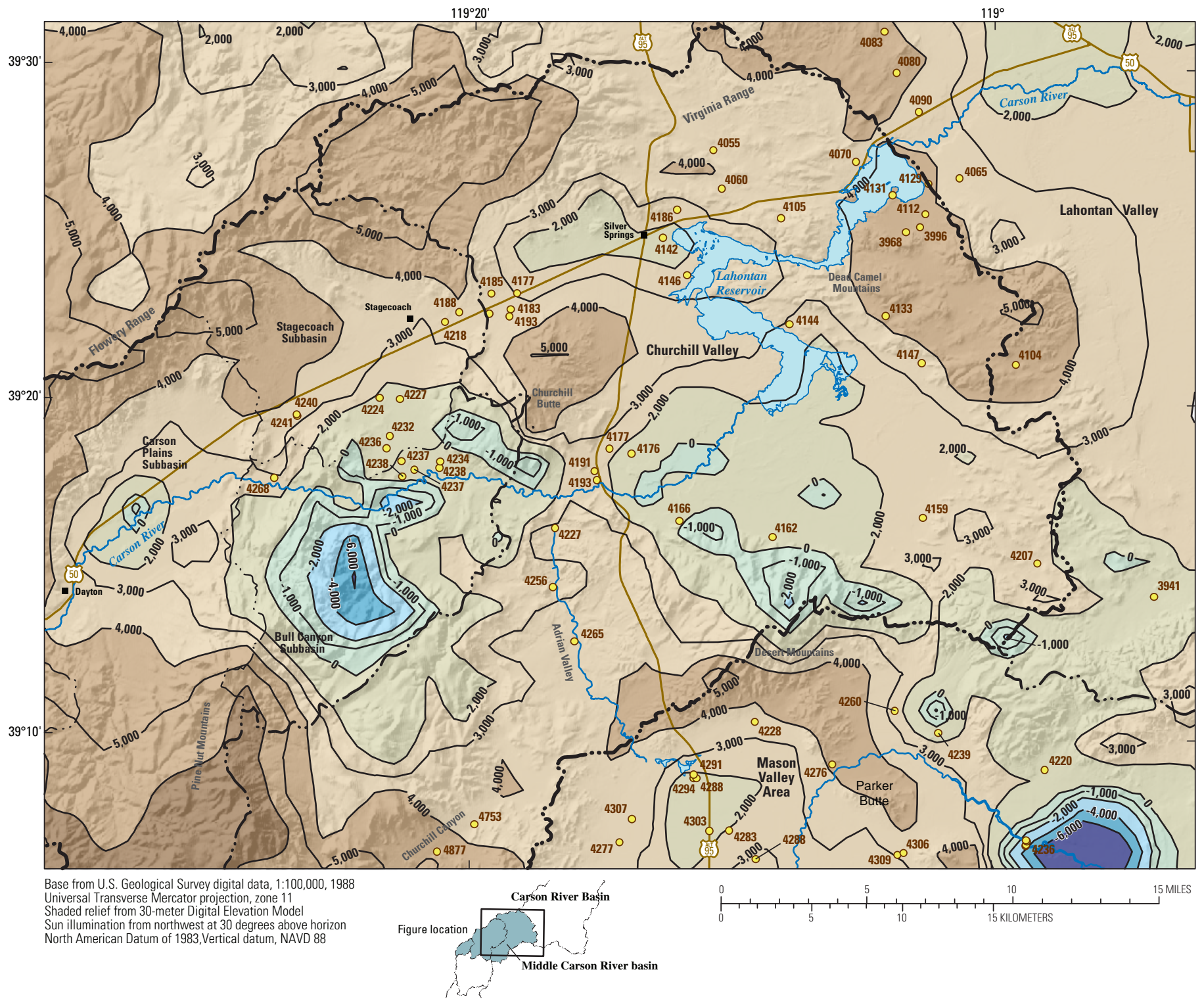

EXPLANATION
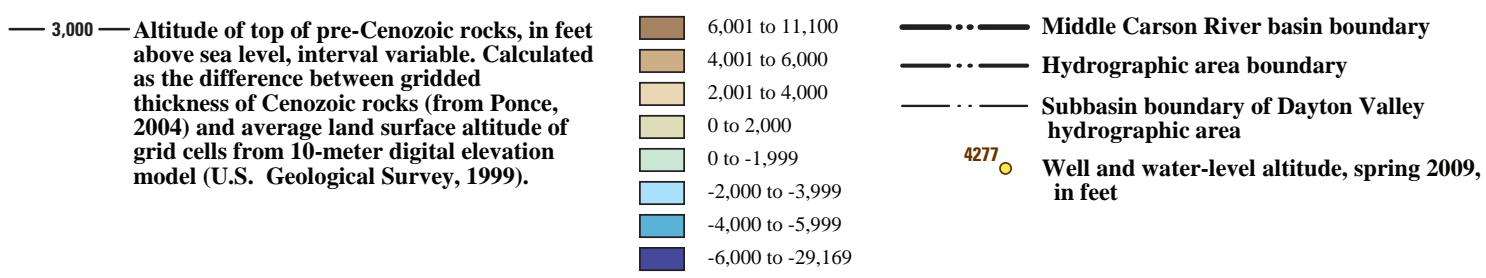

Figure 6. Estimated altitude of the top of pre-Cenozoic rocks, and groundwater altitude at selected wells, middle Carson River basin, Nevada. 


\section{Thickness of Quaternary Basin-Fill Sediments}

Maps of the estimated thickness of Quaternary basinfill sediments for Eagle Valley and the Stagecoach subbasin have been compiled in previous studies (Arteaga, 1986, p. 26; Harrill and Preissler, 1994, p. 13). The thickness of basin-fill sediments also was estimated beneath a cross section in the Carson Plains subbasin, and beneath two cross sections in central and southeastern Churchill Valley by Schaefer and Whitney (1992, p. 6-7). The map for Stagecoach Valley shows more than 3,000 ft of basin-fill sediments west of Misfits Flat. The geologic map used for this study, however, shows basaltic volcanic rock exposed where the basin-fill thickness of 3,000 ft was estimated by Harrill and Preissler (1994), suggesting their estimate may be in error. For this reason, new estimates of the thickness of basin-fill sediments in the Carson Plains and Stagecoach subbasins and in Churchill Valley and western Lahontan Valley were made for this study.

Gravity data from 736 stations in and near the middle Carson River basin (ig. 7) were used to estimate the thickness of Quaternary basin-fill sediments in the eastern part of the study area. Gravity data for most of the stations were obtained from a dataset compiled by the National Geophysics Data Center (National Oceanic and Atmospheric Administration, 1999). Gravity measurements were made at 95 new stations for this study where existing gravity data were sparse. Measurements at the new stations were processed to obtain the complete Bouguer anomaly at each station, assuming a bedrock density of $2.67 \mathrm{~g} / \mathrm{cm}^{3}$ and using software developed by Geosoft, Oais montaj, version 7.1.1. The new station data were then merged with the dataset obtained from NOAA for analysis.

Estimates of the thickness of basin-fill sediments were made using gridded residual gravity values and a regression between basin-fill thickness and residual gravity (ig. 8). Residual gravity values were calculated by subtracting a grid of the regional gravity field derived from those stations located on bedrock outcrops from a grid of the total gravity field derived using all stations (Telford and others, 1976, p. 50-56). Figure 7 shows a regional gradient of the complete Bouguer anomaly ranging from about $-200 \mathrm{mGal}$ west of Carson City to about -150 mGal east of Lahontan Reservoir. Complete Bouguer anomalies for stations on the valley floor are more negative than the values for stations in the adjacent mountain blocks, a consequence of the thickness and lower density of unconsolidated basin-fill sediments. The regional and total field gravity grids were developed from the gravity measurements using GIS software for interpolation of the data to produce a $10-\mathrm{m}$ grid. The grids were subtracted using GIS software to produce a grid of the residual gravity values. In theory, the residual gravity values are proportional to the thickness of unconsolidated sediments, whose density is less than that of the underlying consolidated rocks. The density of unconsolidated sediments is about $2.00 \mathrm{~g} / \mathrm{cm}^{3}$ based on values reported by Maurer (1985, p. 4) for other studies in Nevada. The resulting grid of residual gravity values were generally near zero close to bedrock exposures, and were positive in the valleys.

Lithologic descriptions from 25 driller's logs (see locations in fig. 9) were then used to develop a regression between residual gravity and the thickness of unconsolidated basin-fill sediments (fig. 8). The regression was applied to the grid of residual gravity to produce a grid of basin-fill thickness that was contoured using GIS software. The mapped exposures of consolidated rocks and lithologic descriptions from selected driller's logs for deep wells that either did or did not penetrate consolidated rocks (appendix A) were used to adjust the machine-generated contours to provide contours that best fit all available information. The logs were selected from the well-log database maintained by the Nevada Division of Water Resources (http://water.nv.gov/Engineering/wlog/wlog. $\underline{\mathrm{cfm}}$ ) and well locations were checked with parcel maps to ensure correct location.

The resulting contours of the thickness of unconsolidated basin-fill sediments generally show sediments are less thick than estimated in previous studies (figs. $9 A$ and $\underline{9 B}$ ). In Carson Plains, basin-fill sediments are thickest, more than $1,000 \mathrm{ft}$, about 4 mi northeast of Dayton (fig. 9A). The cross section developed by Schaefer and Whitney (1992, p. 6) indicates a thickness of about 2,000 ft at this location. Similarly, in the Stagecoach subbasin, basin-fill sediments are thickest, more than $800 \mathrm{ft}$, beneath the western part of the subbasin, and are more than $600 \mathrm{ft}$ beneath the northeastern part of the subbasin. The map developed by Harrill and Preissler (1994, p. 13) shows thicknesses of more than 1,000 and 2,000 ft in these locations, respectively. In Churchill Valley, basin-fill sediments are thickest, more than $1,000 \mathrm{ft}$, about $5 \mathrm{mi}$ west of Silver Springs, and more than $800 \mathrm{ft}$ thick beneath the Carson River in the southern part of the valley. The cross sections developed by Schaefer and Whitney (1992, p. 7) indicate a thickness of about 2,000 ft near Silver Springs and in the southern part of the valley. Basin-fill thickness is estimated to exceed 1,200 ft near the intersections of U.S. Highway 95 and U.S. Highway 50 in Lahontan Valley. 


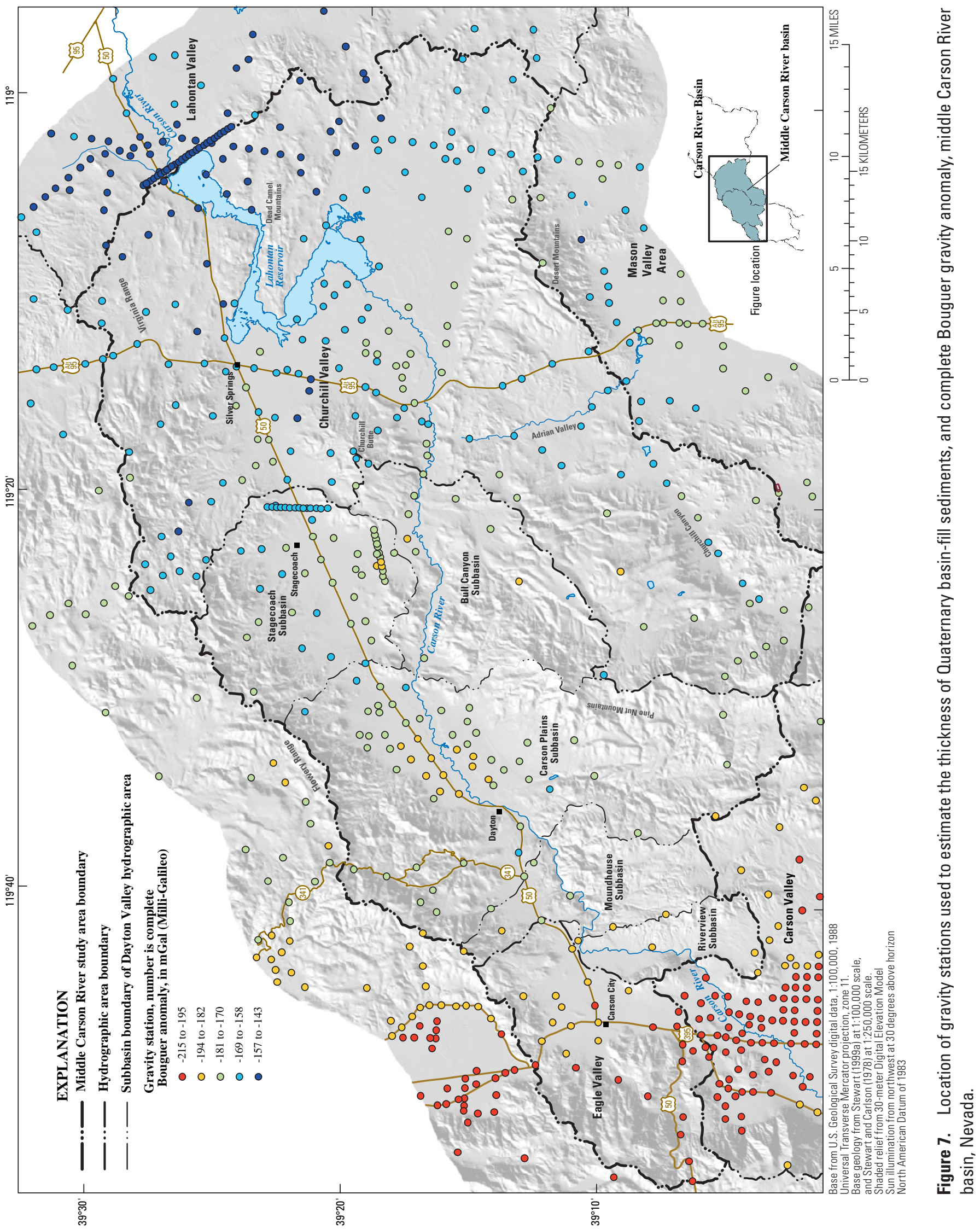




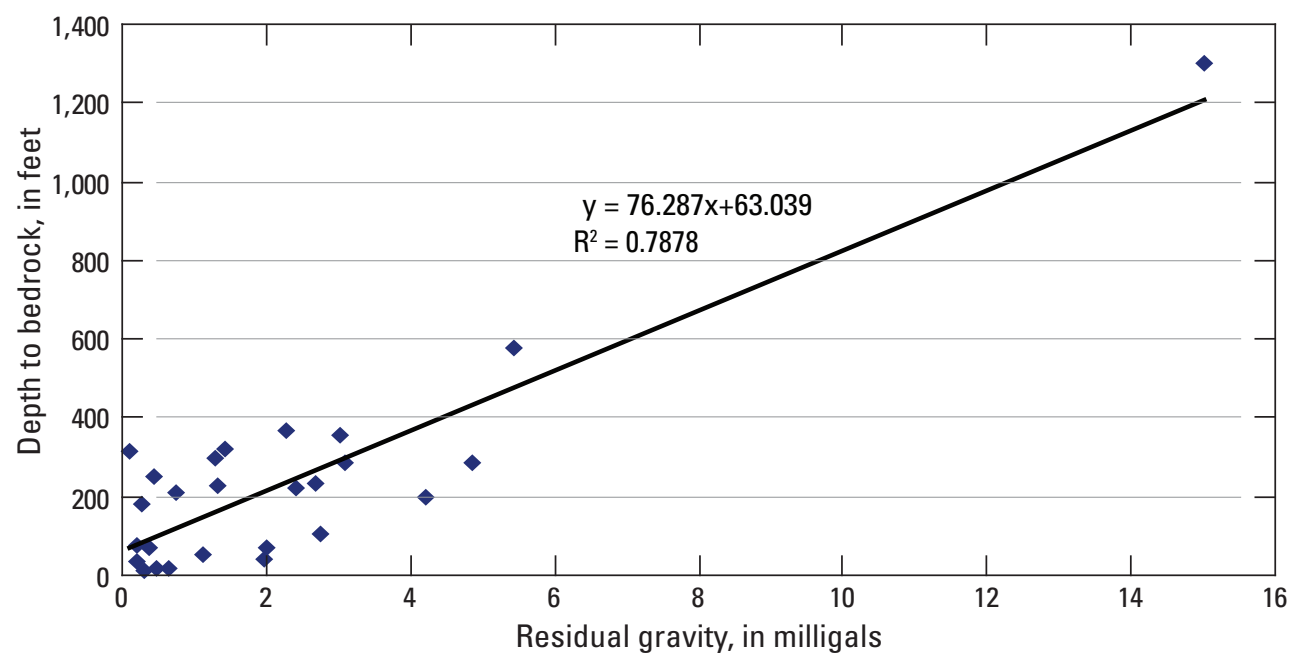

Figure 8. Relation between residual gravity and thickness of unconsolidated basin-fill sediments from lithologic descriptions on driller's logs for selected wells, middle Carson River basin, Nevada.

The presence of semi-consolidated Tertiary sediments underlying Tertiary volcanic rocks or basin-fill sediments may explain some of discrepancies in the estimates of basin-fill thickness. The driller's log for the well southwest of Misfits Flat in the Stagecoach subbasin encountered consolidated rock from 7 to $135 \mathrm{ft}$ below land surface; then clay, sand, and gravel to $380 \mathrm{ft}$, which are likely semi-consolidated Tertiary sediments underlying Tertiary volcanic rocks (fig. 9A). Sediments, likely of Tertiary age, underlying consolidated rocks have been reported in driller's logs at several wells near the valley margins (figs. $9 A$ and $\underline{9 B}$ ). The Tertiary sediments may underlie unconsolidated basin-fill sediments at many locations in the study area, and are difficult to distinguish from the unconsolidated sediments on the basis of gravity data alone, or from driller's log descriptions. For this reason, estimates of the thickness of basin-fill sediments made for this study are considered to be minimum values representing the most permeable parts of the basin fill sediments. 


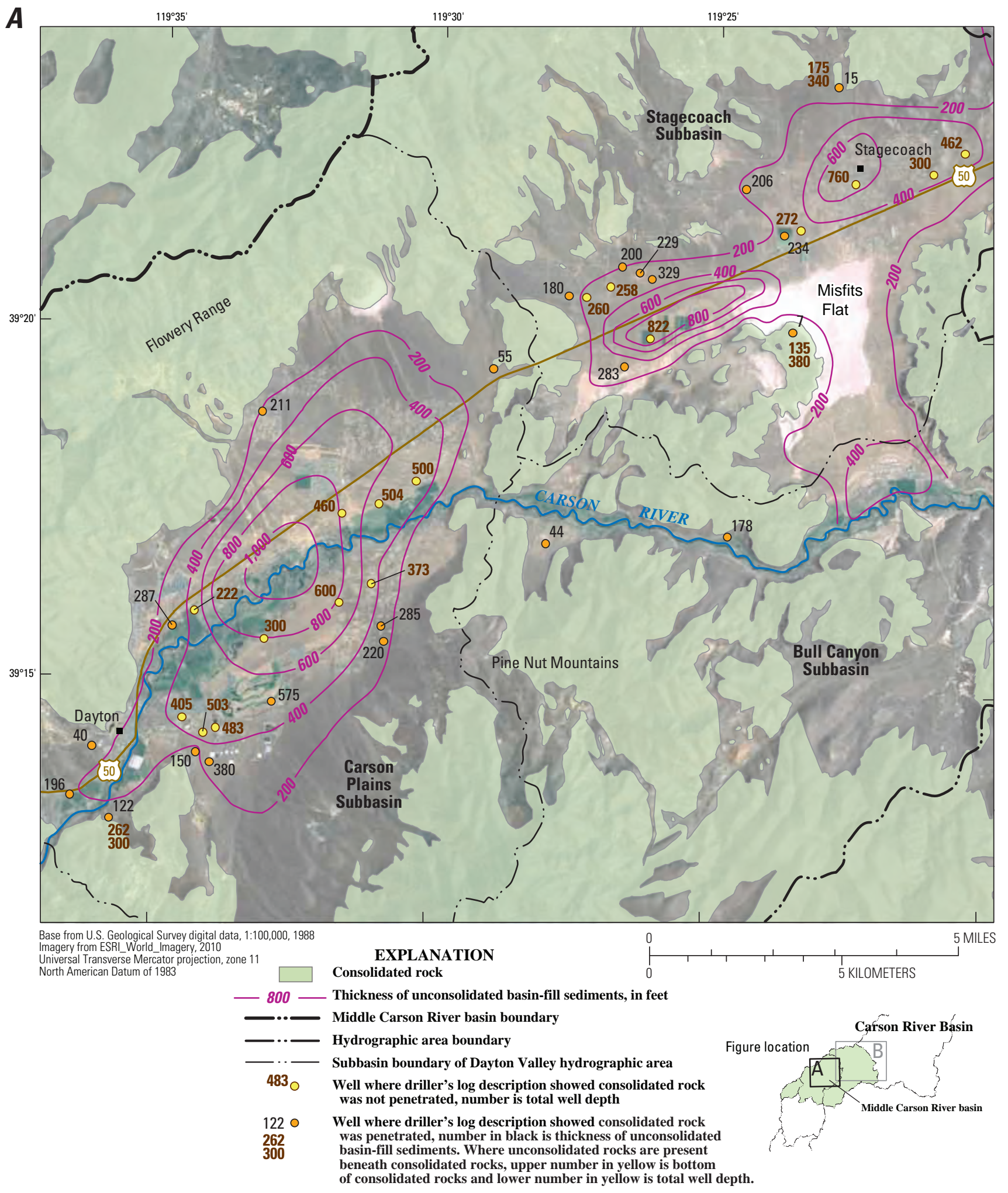

Figure 9. Estimated thickness of unconsolidated basin-fill sediments, middle Carson River basin, Nevada. $(A)$ the Carson Plains and Stagecoach subbasins, and $(B)$ Churchill Valley and western Lahontan Valley, and locations of wells where descriptions on driller's logs indicate the depth at which consolidated rocks were penetrated, the total well depth where such rocks were not penetrated, and the bottom of consolidated rocks and total well depth where unconsolidated rocks were present beneath consolidated rocks. 


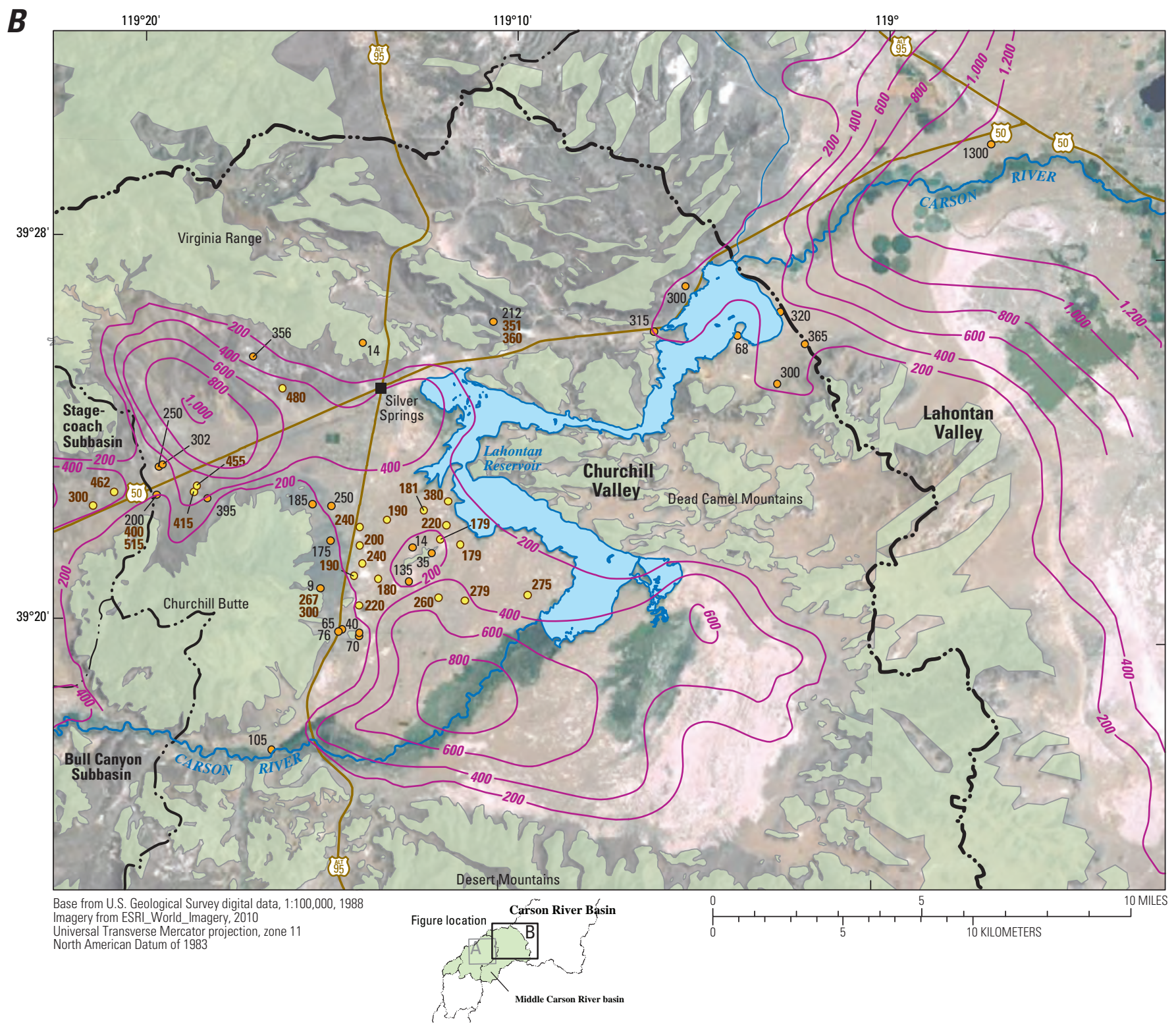

\section{EXPLANATION}

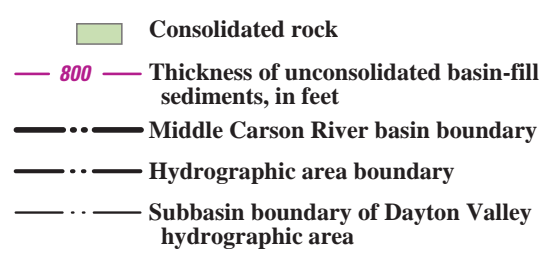

240 - Well where driller's log description showed consolidated rock was not
penetrated, number is total well depth

$200 \circ$ Well where driller's log description

515 showed consolidated rock was penetrated number in black is thickness of

unconsolidated basin-fill sediments.

Where unconsolidated rocks are present

beneath consolidated rocks, upper number

in yellow is bottom of consolidated rocks

and lower number in yellow is total well

depth.

Figure 9.-Continued. 


\section{Hydrogeology}

The movement of groundwater also is controlled by the hydraulic properties of the hydrogeologic units, called aquifer properties in this report, and the hydraulic gradients that drive groundwater flow. Aquifer tests and data from the literature were used to develop maps showing the distribution of hydraulic conductivity and transmissivity mainly for the basinfill hydrogeologic unit, and aquifer storage properties for all hydrogeologic units. Water-level measurements in wells were used to develop updated contours of water-level altitude for each valley and evaluate historical changes in water levels and regional directions of groundwater flow. Fluctuations in water levels and surface-water stage, and streamflow measurements and water-quality data were used to evaluate interactions between the groundwater and surface-water systems in the middle Carson River basin.

\section{Aquifer Properties}

Estimates of aquifer properties that control the movement of groundwater and the volume of water stored in the aquifers are additional requirements for development of a numerical flow model. The hydraulic conductivity of aquifer materials controls the volume of water that can move a through a given cross-sectional area of the aquifer in a given period of time. In general, the hydraulic conductivity of coarse-grained sediments such as gravel and sand is greater than that of fine-grained sediments, such as silt and clay. The sorting of aquifer materials, or the uniformity of grain-size, also greatly affects hydraulic conductivity. Well-sorted sediments, such as beach gravel have greater hydraulic conductivity than poorly sorted alluvial fan sediments. Values of hydraulic conductivity vary over several orders of magnitude for different materials (Freeze and Cherry, 1979, p. 28).

Transmissivity also is a measure of the volume of water than can move through an aquifer, and is equal to the hydraulic conductivity of the aquifer multiplied by its thickness. Similar to hydraulic conductivity, values of transmissivity also vary over several orders of magnitude. Halford and others (2006, p. 469) reported that reliable estimates of transmissivity can be made using single-well aquifer tests, even when the aquifer thickness is not well known.

Specific yield is the ratio of the volume of water that drains from a given volume of an unconfined aquifer when the water table is lowered, and also can be thought as the volume of water stored in an unconfined aquifer. Specific yield values are dimensionless, but are commonly multiplied by 100 and expressed as percentages. Lohman and others

(1972, p. 12) define specific yield as the porosity of an aquifer minus specific retention, the volume of water that remains in storage after gravity drainage. Values of specific yield vary much less than those of hydraulic conductivity, and generally range from 10 percent for fine-grained materials to 30 percent for coarse-grained materials (Davis and DeWeist, 1966, p. 394; Lohman, 1972, p. 8). In confined aquifers, the storage coefficient reflects the volume of water stored in or released from aquifer materials when the aquifer is pumped. Values of the storage coefficient, ranging from $10^{-5}$ to $10^{-3}$, are several orders of magnitude less than specific yield because the aquifer materials are not actually drained (Lohman, 1972, p. 8). Instead, the water is derived from expansion of the water as pumping reduces the pressure in the aquifer and from compression of the aquifer materials (Lohman, 1972, p. 8).

Estimates of aquifer properties for Eagle Valley and the Stagecoach subbasin have been made by Arteaga (1986, p. 22-35) and by Harrill and Preissler (1994, p. 12-16), respectively, and incorporated into numerical models. In a numerical model for Eagle Valley, specific yield was assigned a single value of $0.15 \mathrm{for}$ the upper $100 \mathrm{ft}$ of saturated sediments, and the storage coefficient was assigned values by multiplying the remaining thickness of saturated sediment above the bedrock by $10^{-6}$ (Arteaga, 1986, p. 35). In the Stagecoach subbasin, Harrill and Preissler (1994 p. 12) estimated the distribution of horizontal and vertical hydraulic conductivity on the basis of lithologic descriptions from driller's logs, aquifer tests, and specific capacity information found in driller's logs. The distribution of specific yield was estimated by assigning representative ranges of values to the various types of geologic materials, such as fluvial, lake, and alluvial fan deposits.

For this report, the distribution of hydraulic conductivity was estimated on the basis of slug test data collected and analyzed at 30 monitoring wells in Dayton and Churchill Valleys (fig. 10). In the slug tests, water levels were monitored with a recording transducer while a cylinder was quickly lowered into a well below the static water level, which caused a water-level rise in the well. The rate at which the waterlevel rise dissipated was recorded until returning to static. The process generally was repeated 2 to 3 times in each well and water levels were recorded at 0.1 - or 1-second intervals. The wells used for slug tests were shallow, 2-inch diameter monitoring wells, most of which were drilled to a few tens of feet below the water table (table 1). Because the "slugs" displace small amounts of water at discrete depths, the tests are representative of only a small depth interval of the aquifers and not their entire thickness. The hydraulic conductivity estimated from the tests is assumed to be representative of the upper $50 \mathrm{ft}$ of saturated sediments. The slug-test data were analyzed to obtain an estimate of hydraulic conductivity using a spreadsheet program developed by Halford and Kuniansky (2002). 


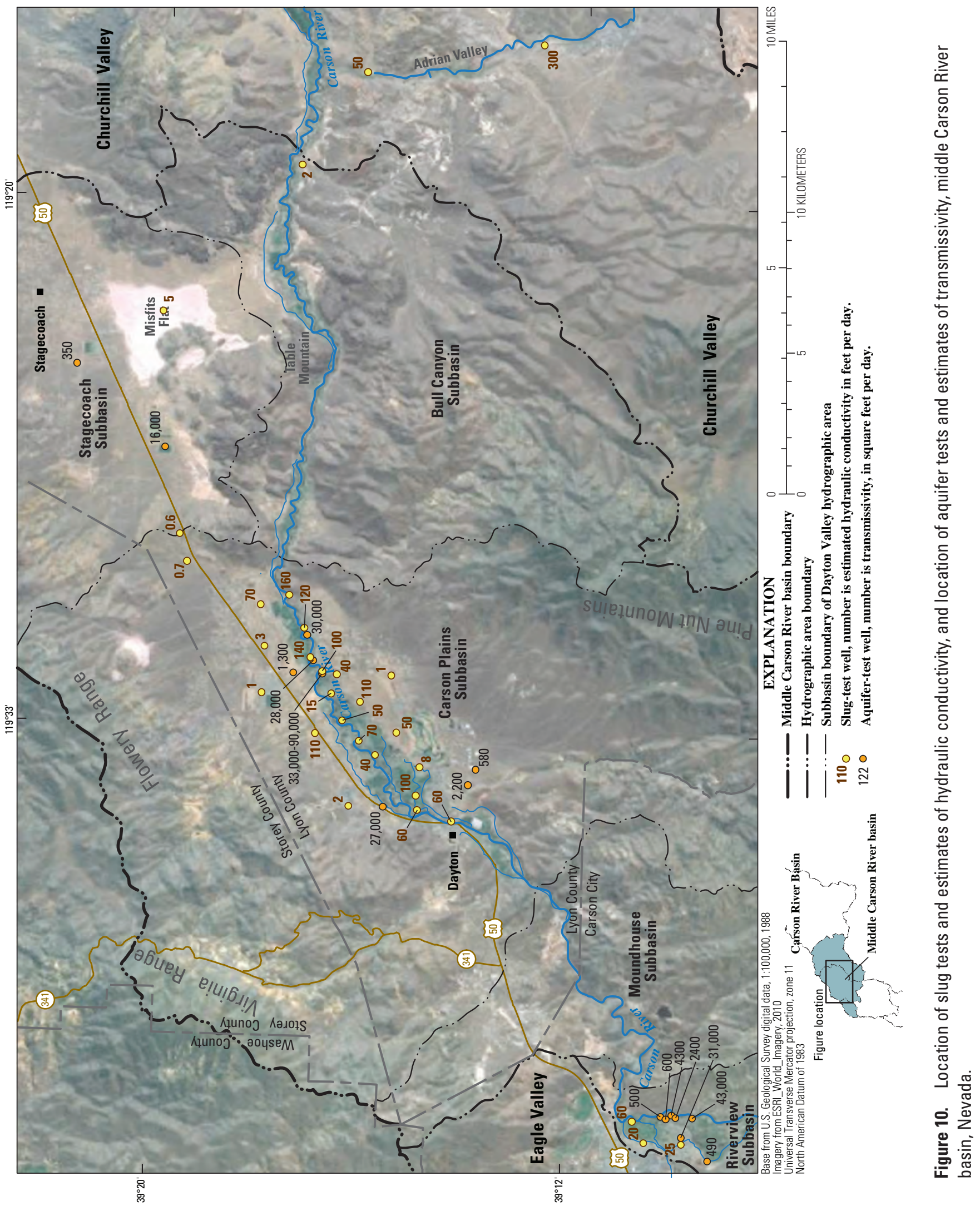


Table 1. Summary of information for slug tests in Riverview, Carson Plains, and Stagecoach subbasins, and Churchill Valley.

[Decimal latitude and longitude: North American Datum of 1983. Hydraulic conductivity estimated using spreadsheet program of Halford and Kuniansky (2002). A bbreviation: ft/d, foot per day]

\begin{tabular}{|c|c|c|c|c|c|c|}
\hline Site identifier & $\begin{array}{l}\text { Decimal } \\
\text { latitude }\end{array}$ & $\begin{array}{l}\text { Decimal } \\
\text { longitude }\end{array}$ & $\begin{array}{c}\text { Screened } \\
\text { interval } \\
\text { (feet below } \\
\text { land surface) }\end{array}$ & $\begin{array}{c}\text { Static water } \\
\text { level } \\
\text { (feet below } \\
\text { land surface) }\end{array}$ & $\begin{array}{c}\text { Date of } \\
\text { test }\end{array}$ & $\begin{array}{c}\text { Hydraulic } \\
\text { conductivity } \\
\text { (ft/d) }\end{array}$ \\
\hline 391038119422701 & 39.17713 & 119.70851 & $5-20$ & 12 & 10-06-09 & 60 \\
\hline 391024119425801 & 39.17324 & 119.71712 & $10-25$ & 22 & 09-22-09 & 20 \\
\hline 390941119425901 & 39.16130 & 119.71740 & $50-70$ & 15 & 09-22-09 & 25 \\
\hline 391416119351401 & 39.23780 & 119.58725 & $25-35$ & 16 & 09-02-09 & 60 \\
\hline 391456119345801 & 39.24886 & 119.58285 & $25-35$ & 18 & 09-02-09 & 60 \\
\hline 391457119343801 & 39.24927 & 119.57713 & $26-36$ & 17 & 09-02-09 & 100 \\
\hline 391454119335501 & 39.24836 & 119.56527 & $35-55$ & 19 & 09-29-09 & 8 \\
\hline 391615119345501 & 39.27074 & 119.58194 & $63-83$ & 50 & 09-09-09 & 2 \\
\hline 391545119333901 & 39.26263 & 119.56080 & $20-30$ & 11 & 09-17-09 & 40 \\
\hline 391522119330501 & 39.25599 & 119.55141 & $71-91$ & 57 & 09-29-09 & 50 \\
\hline 391605119331901 & 39.26797 & 119.55514 & $20-30$ & 8 & 09-17-09 & 70 \\
\hline 391655119330901 & 39.28199 & 119.55242 & $76-96$ & 55 & 09-28-09 & 110 \\
\hline 391625119324801 & 39.27354 & 119.54679 & $18-28$ & 9 & 09-17-09 & 50 \\
\hline 391604119322001 & 39.26785 & 119.53902 & $80-100$ & 57 & 09-29-09 & 110 \\
\hline 391529119314101 & 39.25817 & 119.52802 & $70-90$ & 59 & 09-29-09 & 1 \\
\hline 391638119321001 & 39.27720 & 119.53599 & $25-35$ & 14 & 09-15-09 & 15 \\
\hline 391632119314101 & 39.27567 & 119.52809 & $70-90$ & 59 & 09-29-09 & 40 \\
\hline 391649119313702 & 39.28032 & 119.52692 & $145-165$ & 20 & 09-15-09 & 100 \\
\hline 391703119311701 & 39.28422 & 119.52132 & $5-15$ & 7 & 09-15-09 & 140 \\
\hline 391711119303301 & 39.28647 & 119.50915 & $4-14$ & 7 & 09-15-09 & 120 \\
\hline 391758119321001 & 39.29947 & 119.53622 & $64-84$ & 69 & 09-28-09 & 1 \\
\hline 391711119303301 & 39.29898 & 119.51701 & $70-90$ & 52 & 09-28-09 & 3 \\
\hline 391802119300001 & 39.30056 & 119.50007 & $40-60$ & 27 & 09-28-09 & 70 \\
\hline 391729119294501 & 39.29148 & 119.49575 & $22-32$ & 11 & 10-07-09 & 160 \\
\hline 391928119285901 & 39.32454 & 119.48306 & $110-140$ & 82 & $09-15-10$ & .6 \\
\hline 391937119281801 & 39.32703 & 119.47165 & $245-265$ & 61 & $09-15-10$ & .7 \\
\hline 392002119224901 & 39.33411 & 119.38014 & $52-67$ & 40 & 09-09-09 & 5 \\
\hline 391727119190701 & 39.29088 & 119.31846 & $36-41$ & 27 & 06-03-10 & 2 \\
\hline 391615119164801 & 39.27074 & 119.27990 & $15-20$ & 13 & 06-03-10 & 50 \\
\hline 391252119160201 & 39.21438 & 119.26712 & $19-24$ & 7 & 06-03-10 & 300 \\
\hline
\end{tabular}

Estimates of hydraulic conductivity from the slug tests range from 0.6 to $300 \mathrm{ft} / \mathrm{d}$ (table 1 , fig. 10). The two lowest estimates, 0.6 and $0.7 \mathrm{ft} / \mathrm{d}$, were for two wells completed in fractured granite near the divide between the Carson Plains and Stagecoach subbasins (fig. 10). The remaining slug tests were completed in wells screened in basin-fill sediments. Near the Carson River, hydraulic conductivity is greater than $15 \mathrm{ft} / \mathrm{d}$ to as much as $160 \mathrm{ft} / \mathrm{d}$ in the Riverview and Carson Plains subbasins. Estimates of hydraulic conductivity outside the river flood plain generally are less than $10 \mathrm{ft} / \mathrm{d}$, with the exception of Adrian Valley, where estimates of 50 and $300 \mathrm{ft} / \mathrm{d}$ were made for two wells. The larger estimate is for a well that penetrated well-sorted sediments probably deposited by the Walker River when it flowed through Adrian Valley. An hydraulic conductivity of $5 \mathrm{ft} / \mathrm{d}$ was estimated for a well near the center of Misfits Flat, a playa in Stagecoach Valley. The relatively large value for a well drilled in a playa is the result coarse-grained sand, gravel, and cobbles encountered from 20 to $70 \mathrm{ft}$ beneath overlying playa sediments consisting of finegrained silt and clay. 
Maps that would show the distribution of hydraulic conductivity were not compiled because of the sparse distribution of available slug tests in areas distant from the Carson River flood plain. The slug test data indicate potential ranges of hydraulic conductivity: greater than $10 \mathrm{ft} / \mathrm{d}$ to greater than $100 \mathrm{ft} / \mathrm{d}$ for fluvial sediments near the flood plain, less than $10 \mathrm{ft} / \mathrm{d}$ for basin-fill sediments outside the flood plain, and less than $1 \mathrm{ft} / \mathrm{d}$ for consolidated rocks.

Estimates of transmissivity for basin-fill sediments were made on the basis of data from 16 single-well aquifer tests, generally conducted during the construction of high-producing municipal and industrial wells in Dayton Valley (table 2, fig. 10). Because of the large volume of water pumped and the duration of the tests, the resulting estimates of transmissivity are considered representative of the total thickness of the aquifer being pumped. Estimates of transmissivity approached or exceeded 30,000 ft²/d for wells near the Carson River flood plain in the Riverview and Carson Plains subbasins (fig. 10). Data from a multiple-well test also were analyzed by simulating the test in a three-dimensional numerical flow model developed by USGS (Site Identifier 391649119313801; K. Halford, U.S. Geological Survey, written commun., September 2010), resulting in an estimated transmissivity of $90,000 \mathrm{ft}^{2} / \mathrm{d}$, compared with an estimate of 33,000 $\mathrm{ft}^{2} / \mathrm{d}$ for a single-well test of the same well. The simulation results suggest that the source of pumped water was likely permeable gravel and cobble zones underlying the screened interval of the well at depths of greater than $400 \mathrm{ft}$. Such gravel and cobble zones are described in the logs of nearby wells (see fig. 4 and appendix B).

The specific capacity of pumped wells may be used to develop estimates of transmissivity for areas where aquifer test data are sparse (Lohman, 1972, p. 52). The specific capacity of a well is the rate of discharge, in gallons per minute, divided by the water-level drawdown in the pumping well, in feet, to obtain the volume of water pumped per foot of drawdown. Such information is commonly included on driller's logs. An empirical log-based regression that relates transmissivity estimated from aquifer tests and the specific capacity of 37 wells was made for data from Carson Valley (R. Yager, U.S. Geological Survey, written commun., 2010). The transmissivity and specific capacity calculated from the aquifer tests in Dayton Valley were combined with the regression from wells in Carson Valley for comparison (fig. 11). Log scales were used to plot the specific capacity and transmissivity data because the properties have been found to be log-normally distributed. Equations for the best-fit lines and $\mathrm{R}^{2}$ values (correlation coefficients) shown in figure 11 indicate the regressions explain 79 and 84 percent of the variability of the transmissivity estimated from specific capacity in Dayton and Carson Valleys, respectively. Residuals plots exhibit little evidence of structure in the pattern over time, and the residuals between measured and predicted transmissivity are nearly normally distributed (Helsel and Hirsch, 1992).
The results of aquifers tests in Dayton and Carson Valleys show a similar relation between transmissivity and specific capacity, although estimates of transmissivity were greater for a given value of specific capacity in Dayton Valley. The greater estimates of transmissivity in Dayton Valley could reflect the presence of well-sorted sediments that form the deltas and beaches of Lake Lahontan, and eolian sand deposits, as discussed previously.

The distribution of transmissivity in Eagle, Dayton, Churchill, and western Lahontan Valleys was estimated using the equation between specific capacity and transmissivity from figure 11 and information on well-yield and drawdown reported in about 400 driller's logs (fig. 12). Eagle Valley and the Stagecoach subbasin were included in the analysis to allow comparison of transmissivity estimates with those determined by Arteaga (1986) and Harrill and Preissler (1994). The logs were selected from the well-log database maintained by the Nevada Division of Water Resources (http://water. nv.gov/Engineering/wlog/wlog.cfm, accessed 09/01/10) and, where provided, well locations were checked with parcel maps to ensure correct location. Parcel numbers were not always provided on older logs, however, so that the resulting distribution of transmissivity is considered approximate. Only those wells with a reported yield greater than $30 \mathrm{gal} / \mathrm{min}$ were used in the estimation to ensure that the pumping stress on the aquifer was sufficient to affect a large aquifer thickness.

The resulting distribution of transmissivity shows values exceeding 20,000 ft ${ }^{2} / \mathrm{d}$ generally are near the Carson River in Dayton, Churchill, and western Lahontan Valley (fig. 12). In the Riverview and Carson Plains subbasins, no estimates in the range of 10,000-20,000 $\mathrm{ft}^{2} / \mathrm{d}$ were calculated. Estimates ranging from 1,000 to $10,000 \mathrm{ft}^{2} / \mathrm{d}$ were calculated from data for wells near the Carson River, and transmissivity values less than $1,000 \mathrm{ft}^{2} / \mathrm{d}$ were calculated for wells on alluvial fans near the margins of the valley floors. Values greater than $20,000 \mathrm{ft}^{2} / \mathrm{d}$ were estimated from data for wells north of Misfits Flat in the Stagecoach subbasin, and values greater than $10,000 \mathrm{ft}^{2} / \mathrm{d}$ are found throughout the western part of Churchill Valley, likely reflecting the effect of well-sorted sand and gravel beaches and eolian sand deposited in and near Lake Lahontan. The areal distribution of transmissivity estimates in the Stagecoach subbasin is similar to that reported by Harrill and Preissler (1994, p. 28-30) but the newly estimated values are somewhat greater than model-derived estimates for three separate model layers that include the entire thickness of basin-fill sediments in the Stagecoach subbasin. The transmissivity of the layers ranged from 1,700 to $2,600 \mathrm{ft}^{2} / \mathrm{d}$ and totaled about $6,000 \mathrm{ft}^{2} / \mathrm{d}$. Transmissivity estimates in Eagle Valley agree well with those determined by Arteaga (1986, p. 28, table 4, pl. 3), who reported values from 10,000 to $12,000 \mathrm{ft}^{2} / \mathrm{d}$ on the western side of the valley, from 1,000 to $10,000 \mathrm{ft}^{2} / \mathrm{d}$ near the center of the valley, and less than $1,000 \mathrm{ft}^{2} / \mathrm{d}$ near the margins of the valley. 


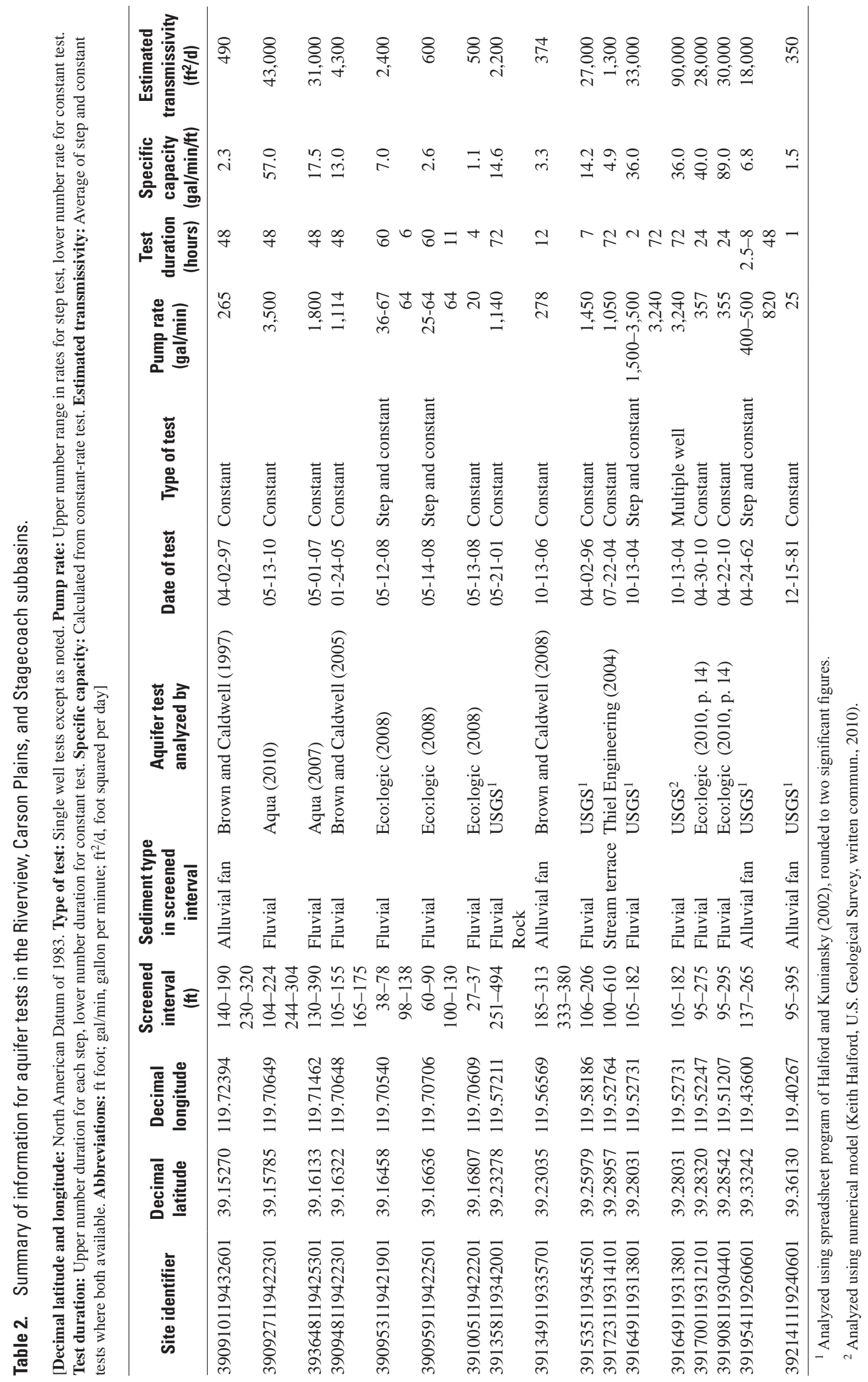




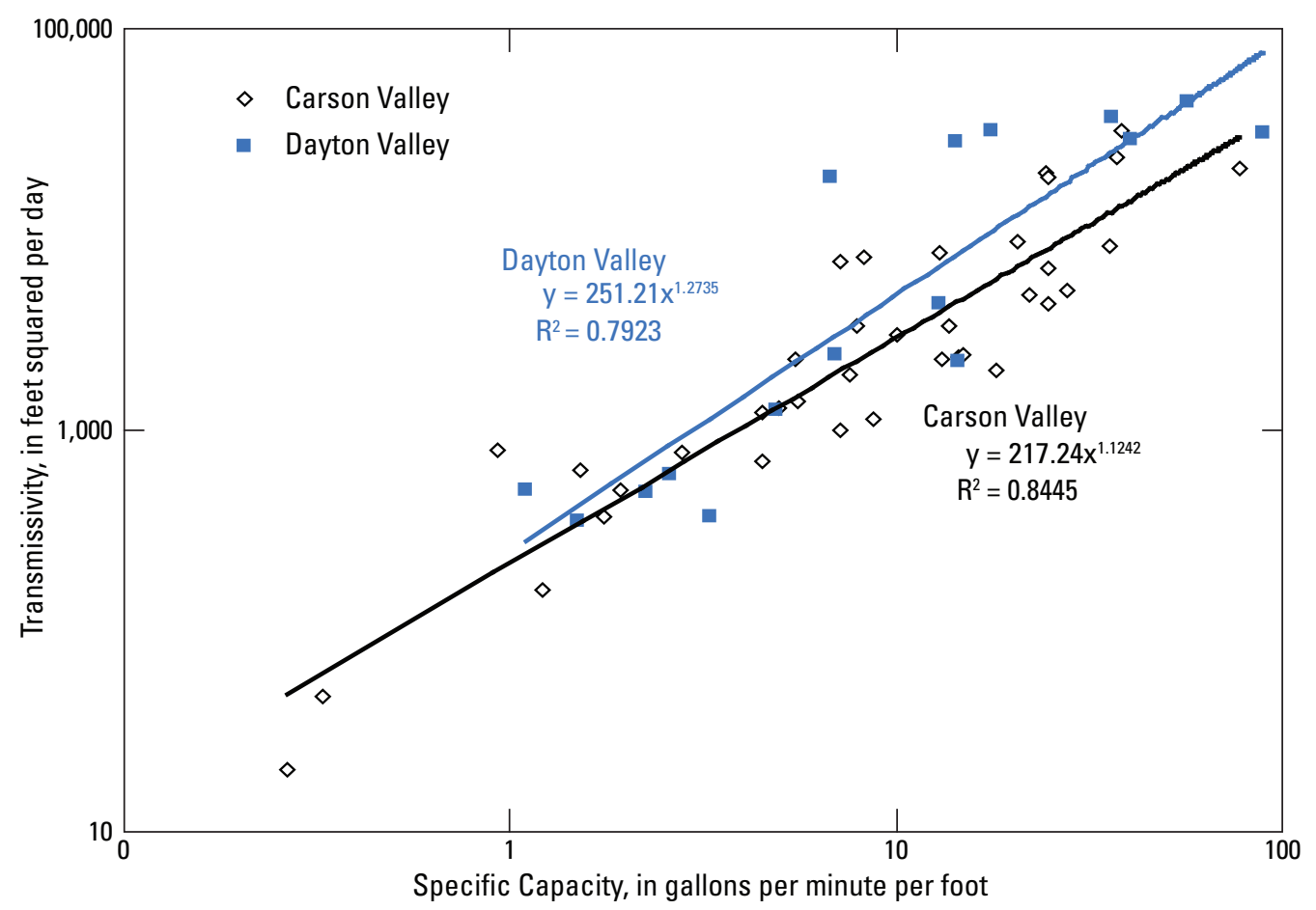

Figure 11. Relation between specific capacity and transmissivity, Carson and Dayton Valleys, Nevada.

Estimates of the transmissivity of consolidated rocks were not made because of the paucity of data. The two estimates of hydraulic conductivity of fractured granite, both less than $1 \mathrm{ft} / \mathrm{d}$, indicate that the transmissivity of most consolidated rocks is considerably less than that of basin-fill sediments. However, the potential for high transmissivity of basaltic volcanic rocks or zones of high transmissivity along fractures in other consolidated rocks remains likely. Additional drilling of test wells in consolidated rocks would aid in determining the potential range of their transmissivity.

The distribution of specific yield in the middle Carson River basin was estimated on the basis of geologic units mapped by Stewart (1999a; fig. 13). Lithologic descriptions of the units were used to assign a potential range of specific yield values generally based on values reported by Cohen (1963) and Morris and Johnson (1967). Values reported by Cohen were for more than 300 samples collected near the Humboldt River in northern Nevada and analyzed in the USGS Hydrologic Laboratory in Denver, Colorado. Values reported by Morris and Johnson (1967) were for varying numbers of samples for different types of rocks and sediments, together totaling more than 10,000 samples collected throughout the United States and analyzed in the USGS Denver laboratory from 1948 to 1960 . The geologic units were grouped in categories assumed to have similar ranges of specific yield: consolidated rocks, basaltic rocks, Tertiary sediments, alluvial fans, lake deposits, and fluvial deposits. As discussed previously, some of the geologic units mapped by Stewart (1999a) are described as thin gravel, pediment, and eolian sand deposits covering the underlying geologic units of alluvial fans, lake deposits, or basaltic rocks. The thin geologic units were assigned specific yield values representative of the underlying units assumed to be those exposed near their periphery.

Specific yield values for all categories ranged from less than 1 to 40 percent (fig. 13). The specific yield of consolidated rock was estimated to be the lowest, ranging from less than 1 to 2 percent, with the exception of basaltic rock which may have a specific yield as great as 15 percent where highly fractured and vesicular. Cohen (1963, p. 22) lists the specific yield of fresh crystalline bedrock to be 0 percent. Morris and Johnson (1967, p. 16) report the porosity of weathered granite to range from 34 to 57 percent and average 45 percent, and the porosity of basalt to range from 3 to 35 percent and averages 17 percent. Assuming the specific retention of the basalt may be only a few percent, 15 percent may be a reasonable estimate for the high range of specific yield. 


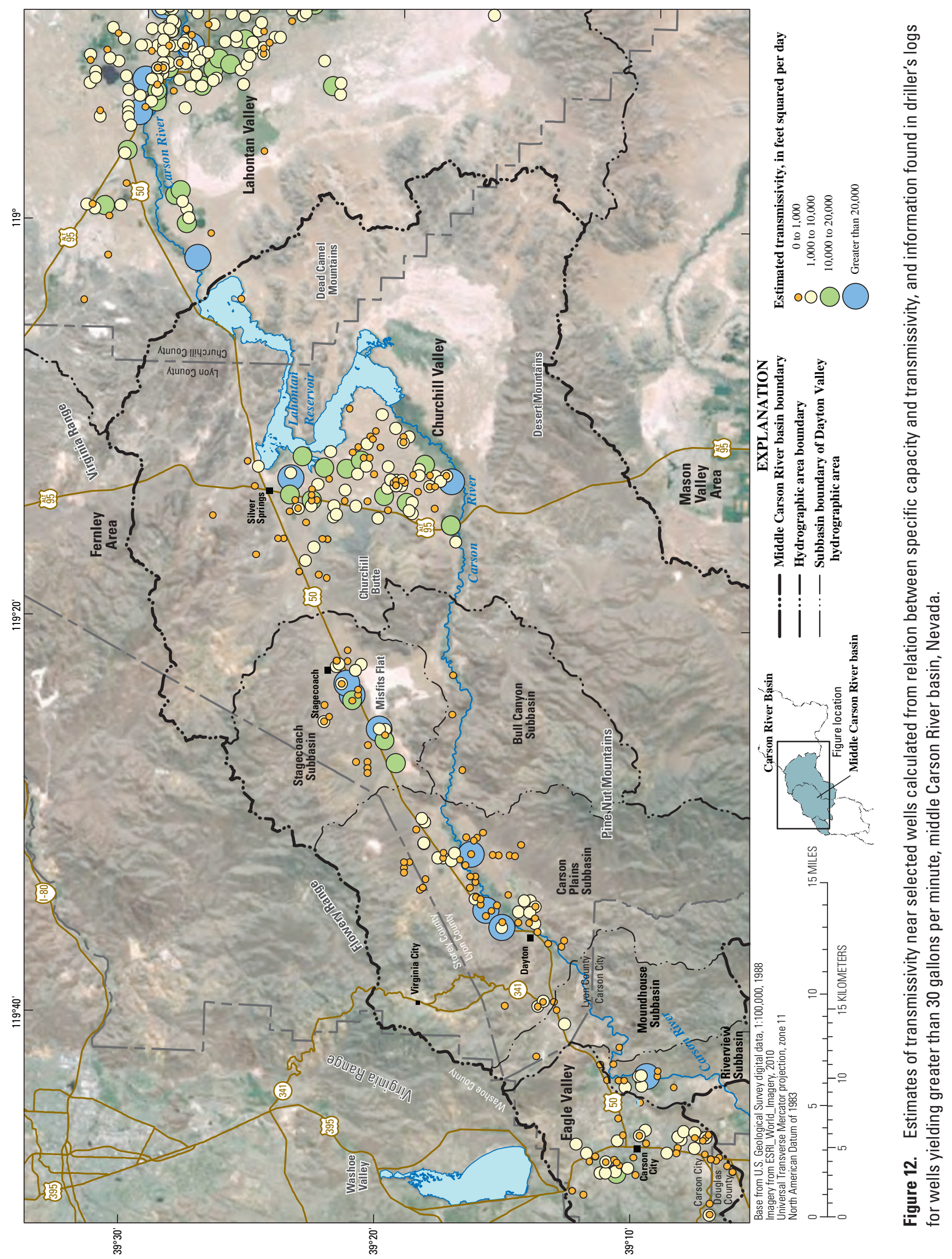




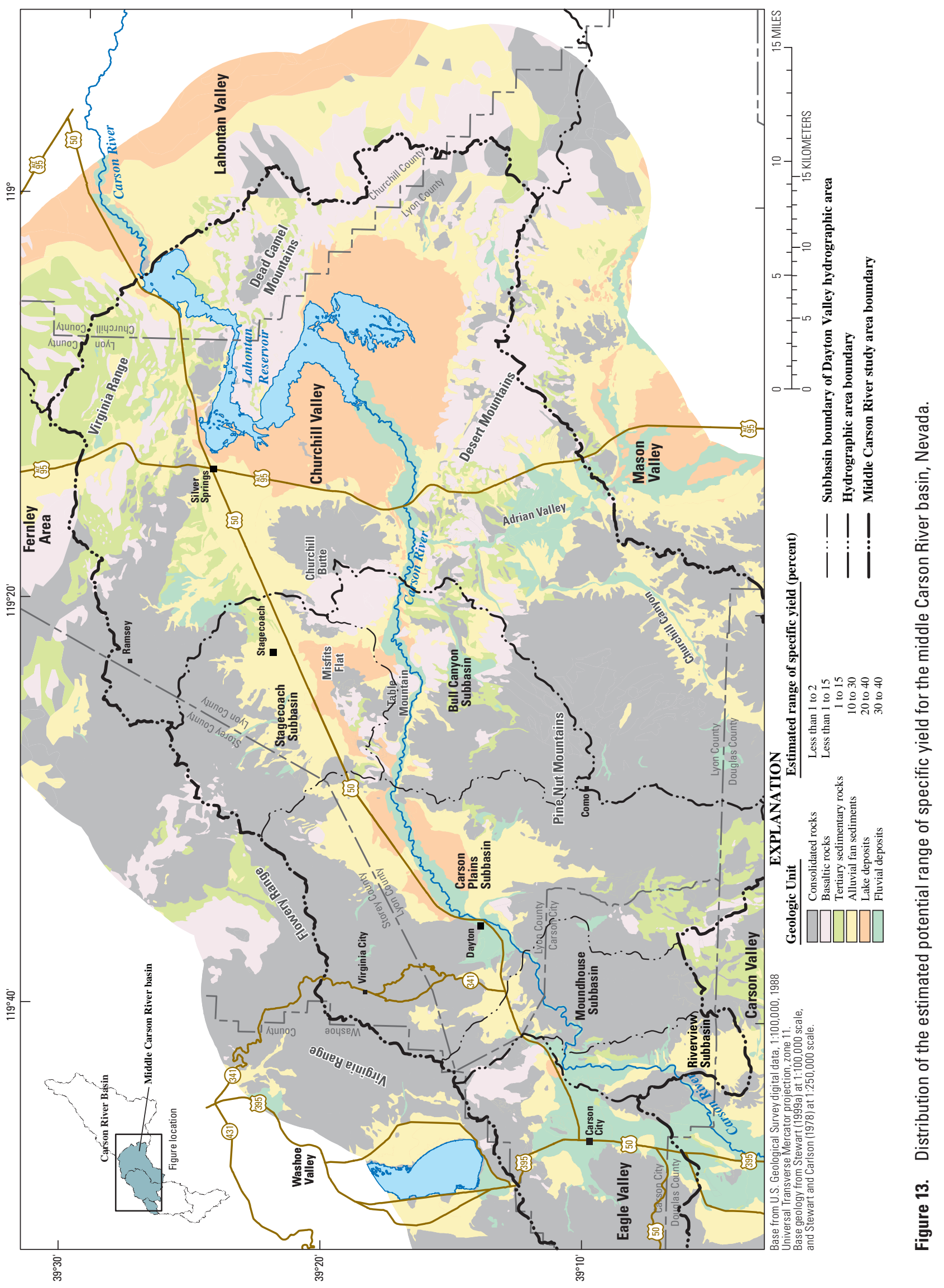


The specific yield of sedimentary deposits is estimated to range from 1 to 40 percent, depending on grain size and sorting. The fine-grained semi-consolidated Tertiary sediments were assigned a range from 1 to 15 percent based on a range of 0.9 to 13 percent and an average of 12 percent for siltstone reported by Morris and Johnson (1967, p. 19), and a range of 5 to 16 percent for cemented sand and gravel reported by Cohen (1963, p. 21). Alluvial fan sediments were assigned a range of 10 to 30 percent based on the range determined by Harrill and Preissler (1994, p. 16) for fans in Stagecoach Valley. Lake deposits were assumed to consist of layers of beach and eolian sand deposits alternating with layers of silt and clay, and were assigned a range of 20 to 40 percent. The range for lake deposits is based on a range of 19 to 29 percent for silt, sand, and gravel deposits in the Humboldt River valley in north-central Nevada reported by Cohen (1963, p. 19), and ranges of 17 to 20 percent for water-laid silt and clay, 28 to 45 percent for water-laid sand, 31 to 44 percent for water-laid gravel, and 32 to 47 percent for eolian sand reported by Morris and Johnson (1967, p. 22-24). The greatest values of specific yield for water-laid sediments reported by Morris and Johnson (1967) were for those with the greatest degree of sorting, which may be expected for beach deposits of sand and gravel, and eolian sand deposits in the middle Carson River basin. Fluvial deposits were assigned a range of 30 to 40 percent based on the reported ranges for water-laid sand and gravel by Morris and Johnson (1967).

\section{Groundwater Levels and Regional Groundwater Flow}

Groundwater levels and directions of groundwater flow in the valleys of the middle Carson River basin have been recently described by Maurer and others (2009, p. 20-21). The descriptions were based on contours of water-level altitude published in previous reports from the mid-1960s and 1980s for Eagle Valley, the early 1980s for the Stagecoach subbasin of Dayton Valley and for Churchill Valley, and from the mid-1990s for the Riverview, Moundhouse, and Carson Plains subbasins of Dayton Valley. Ten water-level monitoring wells were installed for this study, primarily in areas where groundwater-flow directions were considered uncertain by previous investigators (table 3). Water-level measurements at these and other wells were used to update contours of waterlevel altitude for each valley. The updated contours provide a means to evaluate long-term water-level changes and regional groundwater-flow directions.

Water-level measurements were made for this study at about 300 wells during April 2009. Measurements at about 50 of the wells were made by personnel from the Nevada Division of Water Resources (data downloaded from http:// water.nv.gov/well\%20net/download data.cfm, accessed May 5, 2009), from Lyon County (Scott Fleckenstein, Lyon County Utilities Department, written commun., April 2009), and from Carson City (Kelly Hale, Carson City Utilities Department, written commun., May 2009). Well locations were determined using a hand-held Global Positioning System (GPS) and are considered accurate to $\pm 20 \mathrm{ft}$. Measurements were made with steel and electric tapes and are considered accurate to $\pm 0.01 \mathrm{ft}$. Most of the wells measured in Eagle Valley were unused monitoring wells installed by the USGS for previous studies, and by the office of the State Engineer. In the Carson Plains subbasin, about 30 of the wells measured also were unused monitoring wells installed by Lyon County Utilities. Most of the remaining wells measured were private domestic wells, many of which were not in use. Water levels in wells being used were checked by repeat measurements to ensure that water levels were static. Wells that were not being used actively were slugged with water to ensure good communication between the well and the aquifer. All waterlevel data have been stored in the National Water Information System (NWIS) maintained by the USGS.

The measuring point and land-surface altitude for the wells were determined using various methods. The altitude of many of the wells measured in Eagle and Dayton Valleys have been determined in previous USGS studies from optical surveys by USGS personnel and are considered accurate from \pm 0.1 to $\pm 1.0 \mathrm{ft}$. The measuring point and land-surface altitude for wells measured by Lyon County were determined from optical surveys by Tri State Surveying Ltd. (Kenneth Yucamera, Tri State Surveying Ltd., oral commun., July 2009) and are considered accurate to $\pm 0.5 \mathrm{ft}$. Land-surface altitudes at selected wells near the Carson River were determined by overlaying maps of land-surface altitude at 1-ft contour intervals on the well locations using GIS software. The maps were developed from a Light imaging and Detection and Ranging (LiDAR) survey of the Carson River basin in 2004 (BAE SYSTEMS Advanced Technologies, Inc., 2004). Landsurface altitudes determined from the LiDAR survey were determined to be accurate to within $\pm 0.5 \mathrm{ft}$ by a Differential Global Positioning System (DGPS) survey of selected points (Maurer and others, 2009, p. 76). Measuring point altitudes at newly visited wells in Eagle, Dayton, and Churchill Valleys distant from the river were surveyed using a DGPS. Measuring point altitudes determined using DGPS are considered accurate to $\pm 0.5 \mathrm{ft}$.

Contours of water-level altitude were developed using GIS software and the measured water levels to evaluate groundwater flow directions in each valley (igs. 14A- 14D). The contours were drawn using water levels in all available wells including wells screened in different hydrogeologic units. In western Eagle Valley, where granitic and metamorphic rocks are relatively impermeable to groundwater flow, the extent of water-level contours was limited to unconsolidated basin-fill sediments. In the remainder of the study area, water-level contours were extended into areas of Tertiary volcanic rocks and sediments of variable permeability, where groundwater flow may take place. The 
Table 3. Location, construction, and lithologic information for 2-inch monitoring wells installed for this study.

[Decimal latitude and longitude: North American Datum of 1983. A bbreviation: ft foot]

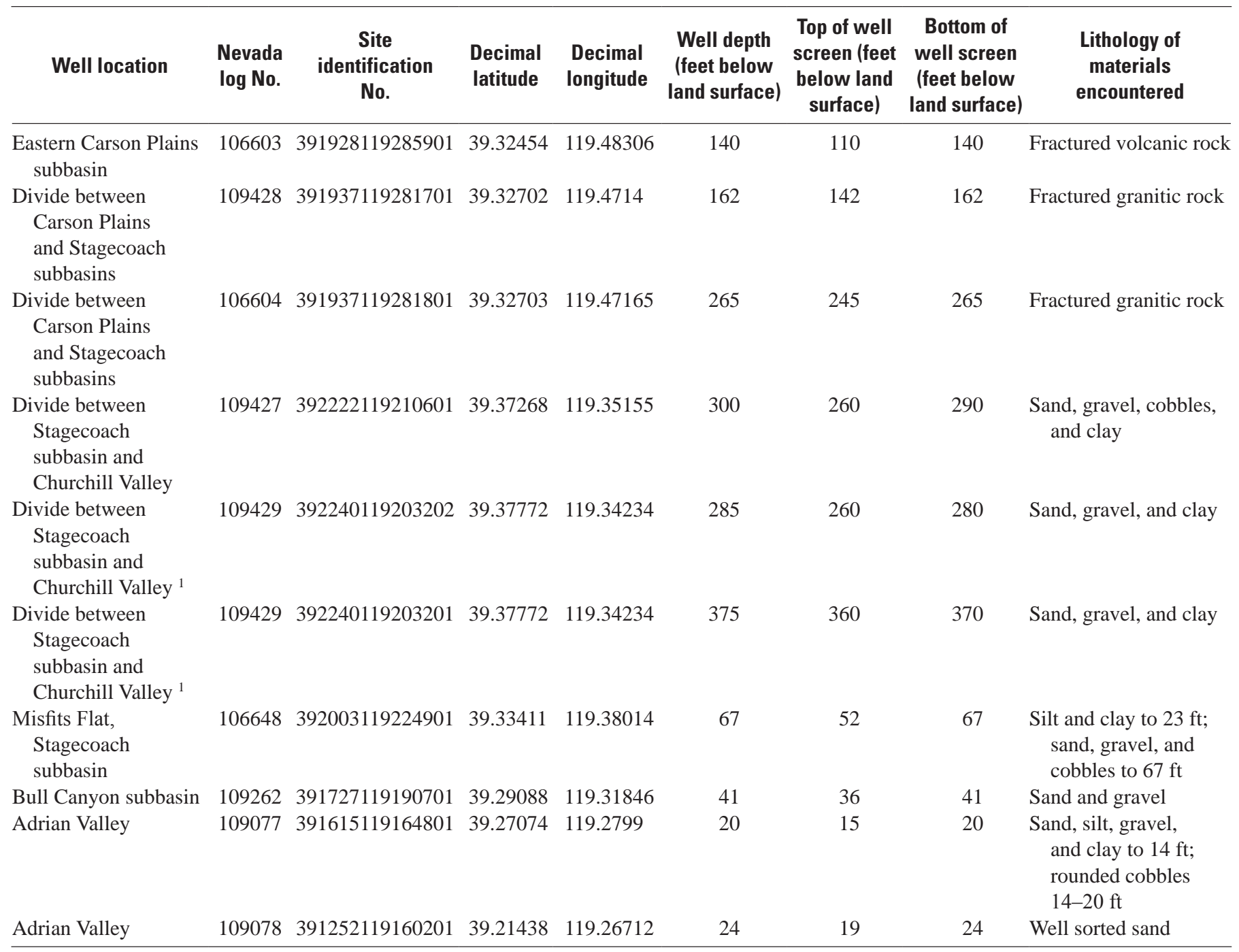

\footnotetext{
${ }^{1}$ Indicates nested wells installed in same borehole.
}

Tertiary rocks and sediments appear to be the source of water for many domestic wells drilled near the edges of the valley floors in Dayton and Churchill Valleys. It should be noted that differences in well depth between the measured wells may result in different water levels to be measured in nearby wells where a vertical hydraulic gradient is present. Similarly, differences in water levels may be measured in nearby wells, which are screened in different types of aquifers, for example, basin-fill sediments and consolidated rocks, where a vertical gradient exists between the two aquifers. The magnitude and direction of the vertical hydraulic gradient was been measured at well pairs screened at different depths in Eagle Valley and the Stagecoach subbasin (figs. 14A and $\underline{14 C}$ ), but is not known in much of the study area. For this reason, contours of waterlevel altitude shown in figures $14 A-\underline{14 D}$ are considered to be only approximately located.
On the northwestern side of Eagle Valley, closely spaced water-level contours indicate a steep horizontal gradient and eastward groundwater flow from the mountain front toward the valley floor (fig. 14A). Groundwater moves toward the southeast in the northern part of Eagle Valley, across the basin divide, and into the northern part of the Riverview subbasin. A groundwater divide exists in the southern part of the valley, where water north of the divide flows northeastward toward the center of Eagle Valley, and water south of the divide flows southeastward into Carson Valley and toward the Carson River. Vertical hydraulic gradients measured in well pairs show a downward gradient near the perimeter of the valley from basin-fill sediments to underlying consolidated rocks and within basin-fill sediments on the valley floor. 
A

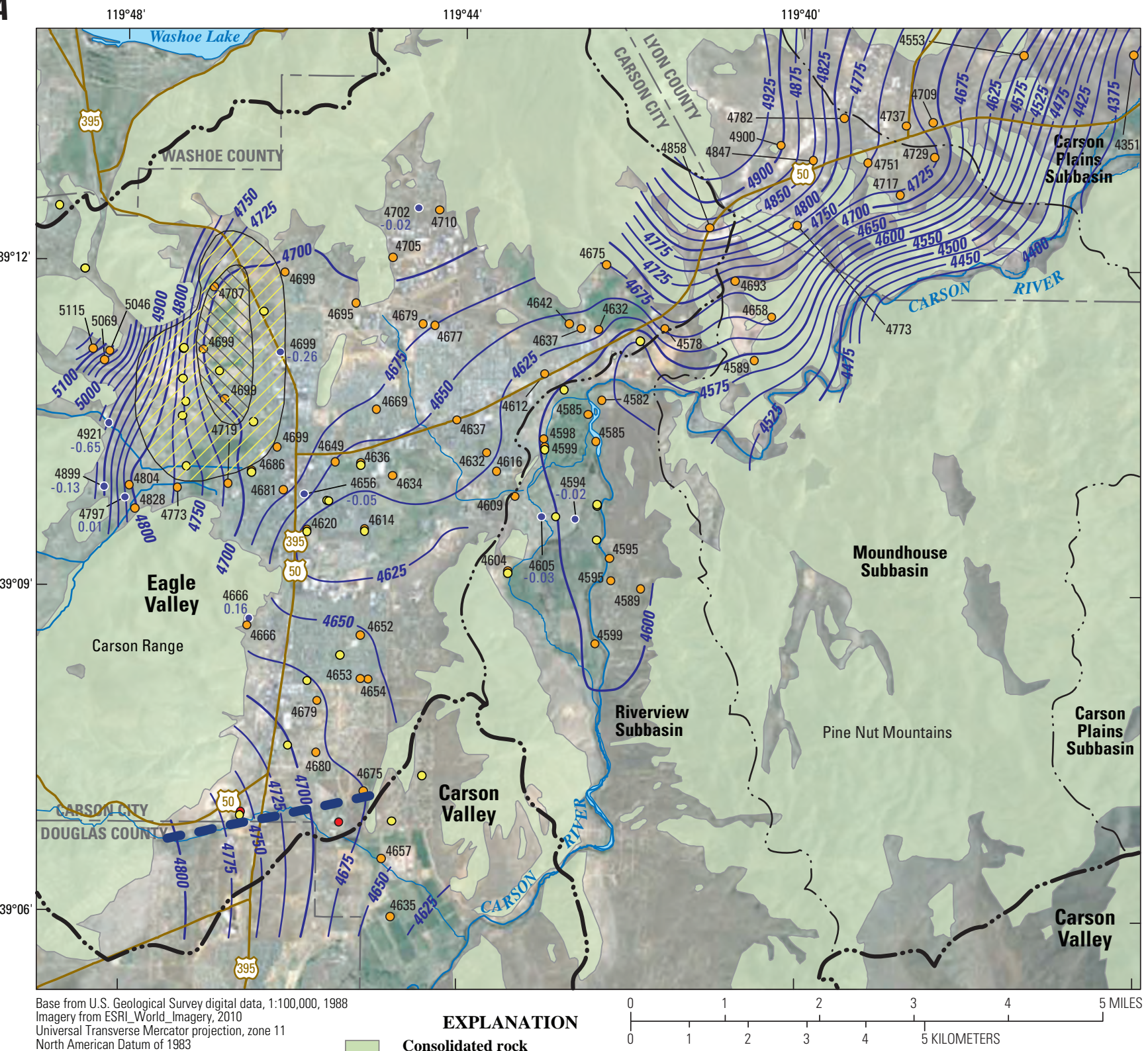

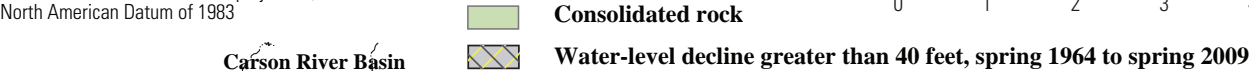

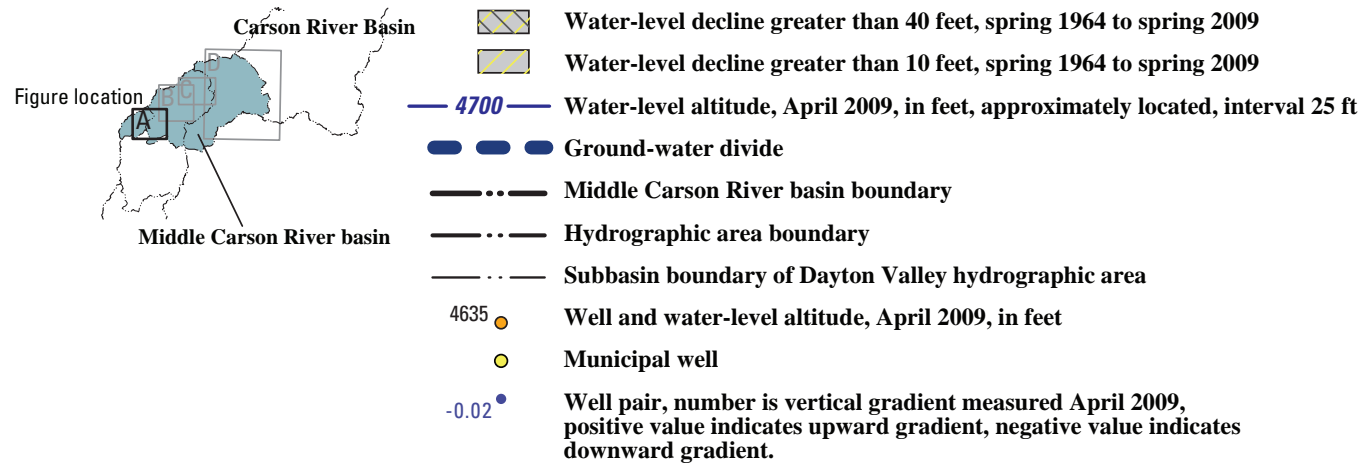

Figure 14. Water-level altitude in April 2009 at selected wells, contours of water-level altitude, and areas of water-level decline in $(A)$ Eagle Valley and Riverview and Moundhouse subbasins, $(B)$ Carson Plains subbasin, $(C)$ Stagecoach and Bull Canyon subbasins, and (D), Churchill, northern Mason, and western Lahontan Valleys, middle Carson River basin, Nevada. 
B

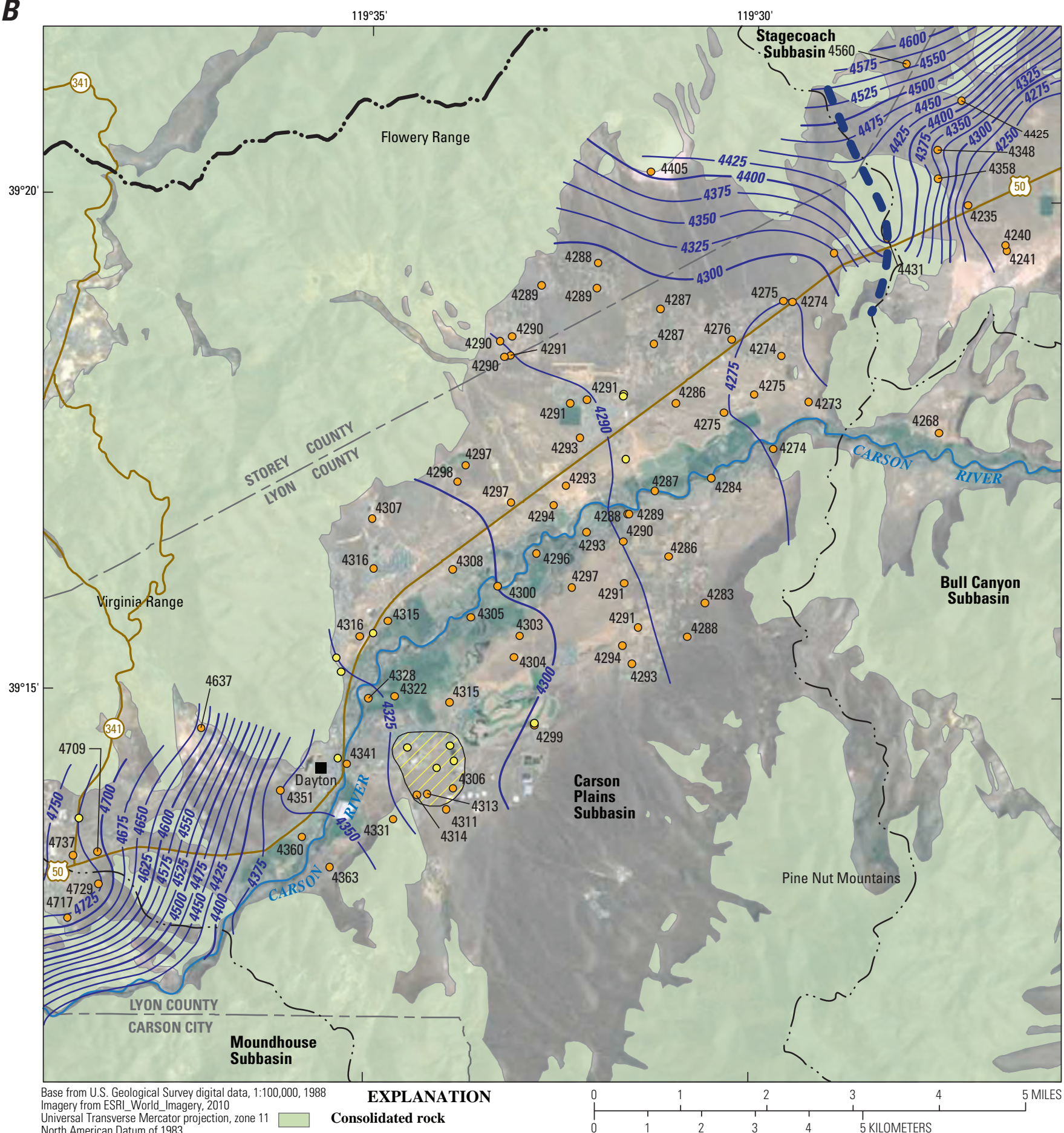

Universal Transverse Mercator projection, zone 11

Consolidated rock

W ater-level decline about 10 feet, 1995 to 2009

— 4700 - W ater-level altitude, A pril 2009, in feet, approximately located, interval $25 \mathrm{ft}$

$\odot \odot$ Ground-water divide

Middle C arson River basin boundary

_... Subbasin boundary of Dayton Valley hydrographic area

4293 W ell and water-level altitude, A pril 2009, in feet

○ Municipal wel

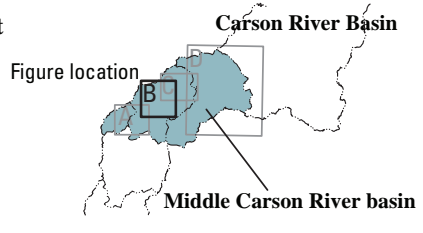

Figure 14.-Continued 
C

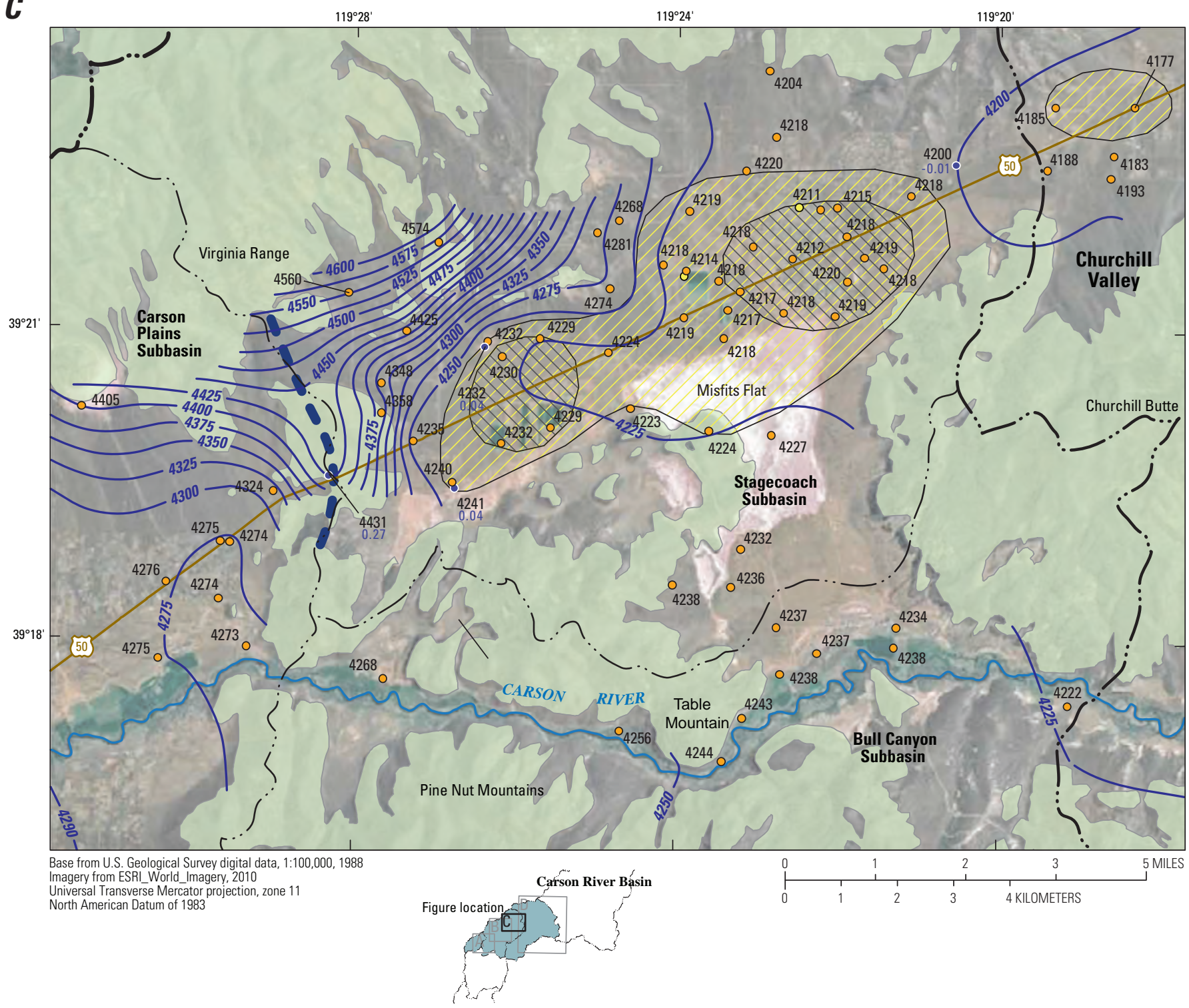

EXPLANATION

Consolidated rock

W ater-level decline about 10 feet, spring 1982 to spring 2009

W ater-level decline about 5 feet, spring 1982 to spring 2009

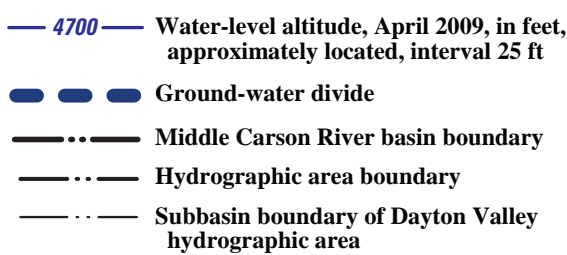

4699 W $\mathrm{Wl}$ and water-level altitude, A pril 2009, in feet

○ M unicipal well

- Well pair, number is vertical gradient measured A pril 2009, positive value indicates upward gradient, negative value indicates downward gradient.

Figure 14.-Continued 
D

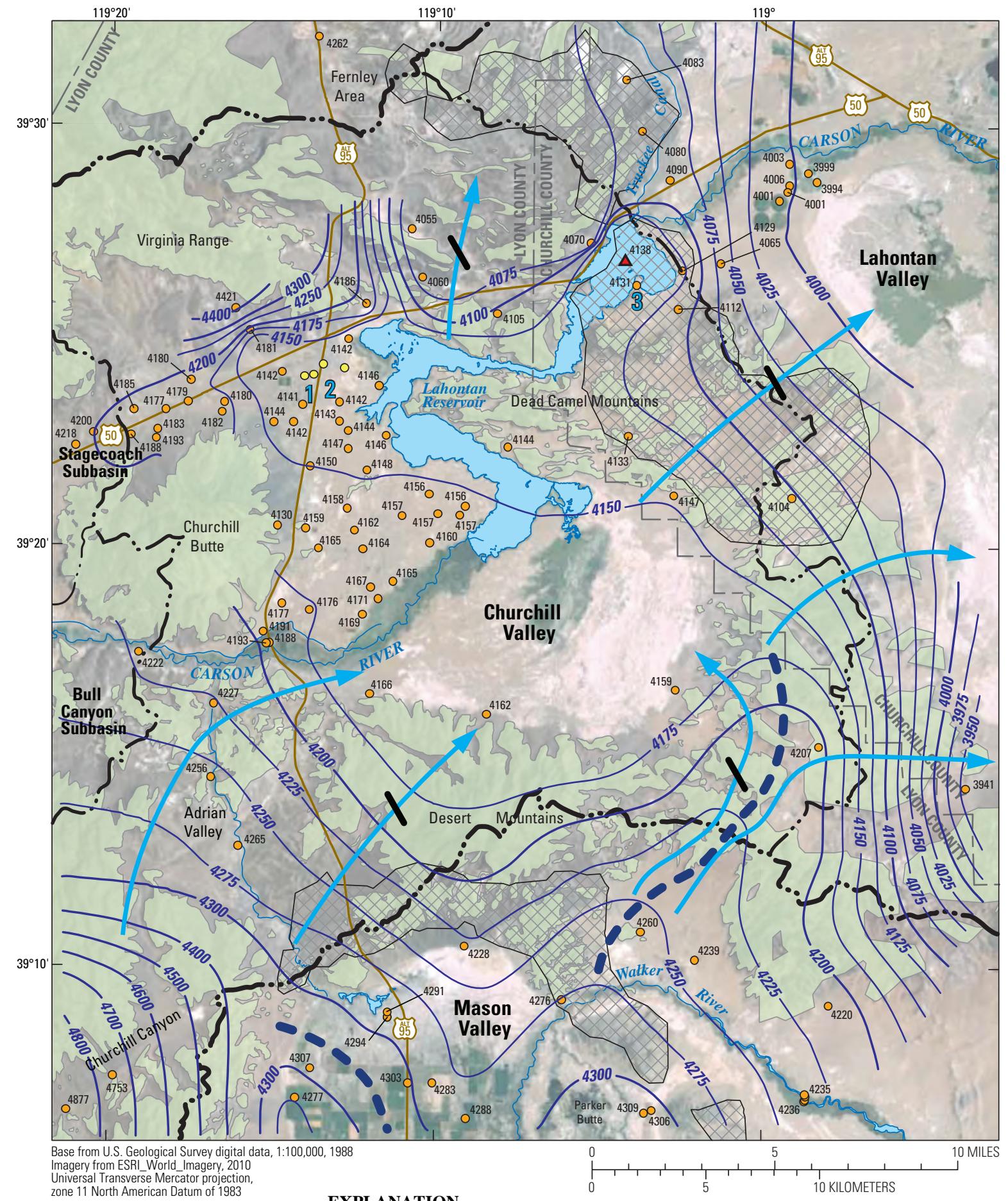

Carson-River Basin .
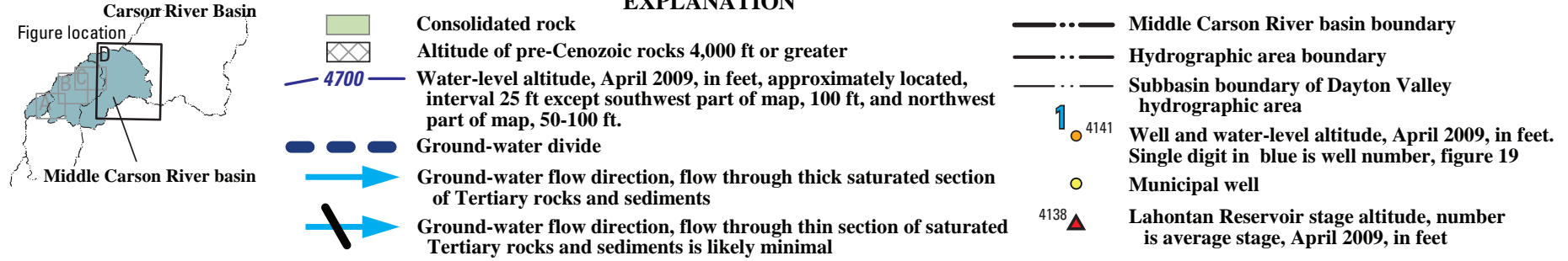

Figure 14.-Continued 
Water levels have declined as much as $70 \mathrm{ft}$ since 1964 at one well in the northwestern part of Eagle Valley. The extent and magnitude of water level declines in northwestern Eagle Valley are difficult to determine precisely because many of the wells measured in the 1960s and 1970s have been abandoned or destroyed, or have gone dry. The extent of hachured areas showing declines of greater than $10 \mathrm{ft}$ and greater than $40 \mathrm{ft}$ in figure 14A was estimated by comparing the contours of water-level altitude from 1964 (Worts and Malmberg, 1966, fig. 4) and 2009. The declines are likely the result of pumping for municipal use on the western side of the valley, which have decreased the southeastward hydraulic gradient in that part of the valley from about $150 \mathrm{ft} / \mathrm{mi}$ in 1964 to about $9 \mathrm{ft} / \mathrm{mi}$ in 2009.

In the Riverview subbasin and most of the Moundhouse subbasin, groundwater moves toward the Carson River. Groundwater flows from the west and east toward the Carson River in the Riverview subbasin, although water-level data are sparse east of the river in the northern part of the subbasin (fig. 14A). Vertical hydraulic gradients measured at well pairs west of the Carson River show a downward gradient within basin-fill sediments. Groundwater in the northwestern and central parts of the Moundhouse subbasin flows south and southeastward toward the Carson River, and in the northeastern part of the subbasin, eastward into the Carson Plains subbasin (figs. 14A and $\underline{14 B}$ ). The steep horizontal hydraulic gradient north of the Carson River in the Moundhouse subbasin indicates limited groundwater flow through poorly permeable ash-flow tuffs. The contours show little change from contours developed for NovemberDecember 1995 in the Moundhouse subbasin by Maurer (1997, pl. 1).

In the Carson Plains subbasin, water-level contours show a low horizontal hydraulic gradient, about $10 \mathrm{ft} / \mathrm{mi}$, across the valley floor, with groundwater moving from southwest to northeast, generally parallel to the Carson River (fig. 14B). The low hydraulic gradient could be the result of either small volumes of groundwater flow or highly transmissive aquifer materials. The contours show a steep eastward gradient from the Moundhouse subbasin and the Virginia Range toward the western side of the valley floor, indicating limited groundwater flow through poorly permeable ash-flow tuffs. Water levels in wells on the valley floor show very little hydraulic gradient toward the Carson River in the southwestern and central parts of the subbasin. The lack of a gradient toward the river on the valley floor may be the result of either small volumes of recharge entering the valley from the Virginia Range and the Pine Nut Mountains, or the result of a highly transmissive aquifer in that part of the valley.

In the northeastern part of the Carson Plains subbasin, the water level in a well screened in consolidated rocks at the southern edge of the Flowery Range shows that groundwater moves from the north toward the valley floor. Water levels in wells installed for this study on the topographic divide between the Carson Plains and Stagecoach subbasins show a distinct groundwater divide between the subbasins, and that groundwater moves southwestward from the divide toward the northeastern part of the Carson Plains subbasin. Maurer (1997, p. 20) reported the potential for groundwater flow from the Carson Plains to the Stagecoach subbasin, based on available water levels on either side of the topographic divide.

Water levels near the western part of the Carson Plains subbasin have declined about $10 \mathrm{ft}$ within a small area $1.5 \mathrm{mi}$ east of Dayton compared with measurements made in 1995 (fig. 14B). The extent of the decline is difficult to determine because measurements in 1995 and 2009 were made in only one well near the area. For this reason, the extent of decline shown in figure $14 \mathrm{~B}$ is considered very approximate. The decline is likely the result of municipal pumping in the area increasing from about 600 acre-ft in 1997 to about 1,500 acre-ft in 2005 (Maurer and others, 2009, p. 26). Water levels in the remaining parts of the Carson Plains subbasin show little change between 1995 and 2009.

Water-level contours in the western part of the Stagecoach subbasin show groundwater flow from the mountain fronts on the west and northwest toward the valley floor (fig. 14C). The steep horizontal hydraulic gradient indicates limited flow through poorly permeable granitic rocks. The vertical hydraulic gradients measured in well pairs on the western side of the valley show an upward gradient within consolidated rocks near the divide and from consolidated rocks to basin-fill sediments. Groundwater flows from southwest to northeast across the western part of the valley floor, with very low horizontal hydraulic gradients north and south of Misfits Flat of about 4 and $3 \mathrm{ft} /$ mi, respectively. As in Carson Plains, the very low gradients may be a consequence of either small volumes of groundwater flow or highly transmissive aquifers. The low gradient north of Misfits Flat may also be the result of groundwater pumping for agricultural and municipal supply. Groundwater flow is northward from the Carson River between Table Mountain and Churchill Butte toward the northeastern part of the subbasin. In the northeastern part of the subbasin water levels show a continuous horizontal hydraulic gradient of about $15 \mathrm{ft} / \mathrm{mi}$ toward the northeast between the Stagecoach subbasin and northwestern Churchill Valley. Harrill and Preissler (1994, p. 10) mapped a groundwater divide between the Stagecoach subbasin and Churchill Valley in 1971. The vertical hydraulic gradient measured in a well pair on the northeastern side of the valley shows a downward gradient within basin-fill sediments. The water-level altitudes measured in the two northernmost wells (altitudes 4,204 and 4,218) indicate a downward vertical hydraulic gradient from basin-fill sediments to consolidated rocks near the northern margin of the valley floor. Harrill and others (1993) provided evidence of groundwater flow from the Carson River flood plain in the western part of the Bull Canyon subbasin into the southwestern part of the Stagecoach subbasin through the intervening basaltic rocks. A 28-ft difference in water levels was measured between the two areas in 2009 (fig. 14C), indicating such flow is still likely. 
Water levels have declined in the Stagecoach subbasin and northwestern Churchill valley since 1982 but have changed little in the Bull Canyon subbasin. Water levels have declined about $5 \mathrm{ft}$ over much of the valley floor and about $10 \mathrm{ft}$ in the western and northeastern parts of the Stagecoach subbasin compared with water levels measured at many of the same wells in the spring of 1982 (fig. 14C; Harrill and Preissler, 1994, p. 22). The declines are likely the result of agricultural pumping in the western part of the subbasin, combined with agricultural and increased municipal pumping in the northeastern part since 1982. Water levels also have declined about $5 \mathrm{ft}$ in the northwestern part of Churchill Valley (fig. 14C). Water levels in the Bull Canyon subbasin are likely maintained by infiltration losses from the Carson River.

In Churchill Valley, groundwater-flow directions are apparent on the valley floor but are uncertain near the basin boundaries (fig. 14D). Water-level contours in northwestern Churchill Valley show groundwater flows eastward from the Stagecoach subbasin and southeastward from the Virginia Range toward the valley floor and Lahontan Reservoir. The steep horizontal hydraulic gradient from the Virginia Range indicates groundwater flow through poorly permeable volcanic rocks. On the valley floor in southern Churchill Valley, contours show that groundwater flow is northward and northeastward parallel to the Carson River and toward Lahontan Reservoir under a low horizontal hydraulic gradient of about $3 \mathrm{ft} / \mathrm{mi}$. As in the Carson Plains and Stagecoach subbasins, the low hydraulic gradient may be the result of either small volumes of groundwater flow or highly transmissive aquifers. The water-level altitudes measured in two wells east of Churchill Butte $(4,130$ and 4,159) indicate a downward vertical hydraulic gradient from basin-fill sediments to consolidated rocks near the western margin of the valley floor.

With the exception of local water-level declines in northwestern Churchill Valley discussed previously, water levels appear not to have changed appreciably in Churchill Valley. This observation, however, is based on comparison of available historical measurements at only two wells in the 1960s and 1980s with measurements in 2009.

Contours and water levels north of Lahontan Reservoir indicate a gradient toward the north and northeast from the reservoir through Tertiary volcanic rocks and sediments. The average reservoir stage of 4,138 ft during the month of April 2009 is significantly greater than water-level altitudes to the north, indicating infiltration losses from Lahontan Reservoir are a likely source of recharge to the area north of the reservoir. Water levels in three wells in western Lahontan Valley north of the Carson River range from 4,080 to 4,090 ft, more than $30 \mathrm{ft}$ higher than water levels of 4,060 and 4,055 measured in two wells about $7 \mathrm{mi}$ to the southeast, in Churchill Valley. Water levels in the three wells north of the river are likely maintained by infiltration losses from the Truckee Canal, which flows at an altitude from 80 to $90 \mathrm{ft}$ higher than the water-level altitudes. It is unclear if groundwater north of the reservoir moves farther north and then eastward toward Lahontan Valley. A water level of 4,262 ft in the southern part of the Fernley Area precludes the potential for groundwater flow northward across the basin divide.

Contours and sparse water-level data on the southeastern side of Churchill Valley show a potential for flow northeastward through Tertiary volcanic rocks and sediments comprising the Dead Camel Mountains and south of the Dead Camel Mountains toward western Lahontan Valley. The driller's log for the well near the basin divide (waterlevel altitude 4,104 ft) describes $420 \mathrm{ft}$ of clay overlying water bearing "lava rock," which is likely permeable basalt, indicating such flow may take place.

Water levels and contours show the potential for groundwater flow from Churchill Canyon toward the north and northeast through Adrian Valley and into the southwestern part of the Churchill Valley floor. In northwestern Mason Valley, contours indicate a groundwater divide that was described by Lopes and Allander (2009, p. 63), with flow south of the divide toward the south, and flow north of the divide toward the northeast beneath the highest part of the Desert Mountains. Contours and water levels east of the Desert Mountains in northeastern Mason Valley and in southeastern Churchill Valley indicate a groundwater divide with potential for flow toward the southeastern part of Churchill Valley west of the divide and toward western Lahontan Valley east of the divide. Lopes and Allander (2009, p. 65) also noted the potential for northeastward groundwater flow along the Wabuska Lineament near the southern base of the Desert Mountains (fig. 3).

It is uncertain if groundwater flow actually takes place beneath the Dead Camel and Desert Mountains. In most parts of northern Nevada, precipitation generally provides sufficient recharge to create groundwater divides beneath mountain blocks. Given the low annual precipitation in Churchill Valley, only about $5 \mathrm{in} / \mathrm{yr}$, groundwater divides may not be present beneath the Dead Camel and Desert Mountains.

If the pre-Cenozoic rocks are assumed to be relatively impermeable to groundwater flow, then the altitude of the top of these rocks provides a means to evaluate groundwater flow directions and provide qualitative estimates of groundwater flow volumes near the boundaries of Churchill Valley. If the altitude of the top of pre-Cenozoic rocks is lower than the altitude of measured water-levels, groundwater may flow through the overlying Tertiary rocks and sediments (ig. 6). Conversely, if the altitudes of the top of pre-Cenozoic rocks are equal to or higher than the altitude of water levels, interbasin groundwater flow probably does not occur or is small, even if there is a hydraulic gradient across the divide.

A comparison of water-level altitudes with the altitude of the top of pre-Cenozoic rocks (ig. 6) shows thick sections of saturated Tertiary rocks and sediments are present through which groundwater flow may take place beneath the eastern part of the Desert Mountains, south of the Dead Camel Mountains, and beneath the northern part of Adrian Valley. 
Water-level altitudes range from about 3,900 to 4,270 ft, or from 900 to 5,000 ft higher than the altitude of preCenozoic rocks. However, groundwater flow from the floor of northeastern Mason Valley toward the northeast is likely restricted by the arm of mountains extending southeast from the Desert Mountains toward Parker Butte. The altitude of the top of pre-Cenozoic rocks beneath the arm is about 4,000 ft, similar to that of the water-level altitudes. Groundwater flow to the northeast, toward western Lahontan Valley, is limited to flow north and south of Parker Butte and flow derived from losses from the Walker River east of Parker Butte as described by Lopes and Allander (2009, p. 63, pl. 1).

Relatively thin sections of Tertiary rocks and sediments are present below the water table north of Lahontan Reservoir, beneath the Dead Camel Mountains, and in southern Adrian Valley (fig. 6). The top of pre-Cenozoic rocks ranges in altitude from 3,000 ft near the northwestern part of Lahontan Reservoir to 4,000 ft near the northeastern part, compared with water-level altitudes of about 4,100 ft. The shallow pre-Cenozoic rocks near the northeastern part of the reservoir likely restrict groundwater flow from northeastern Churchill Valley toward western Lahontan Valley. Similarly, beneath the Dead Camel Mountains water-level altitudes of about 4,100 ft are close to or less than the altitude of the top of pre-Cenozoic rocks, which ranges from 4,000 to 5,000 ft.

The altitude of the top of pre-Cenozoic rocks is about 4,000 ft beneath the southern part of Adrian Valley and about $3,000 \mathrm{ft}$ beneath the northern part, compared with water-level altitudes of about 4,200 ft (fig. 6). Thus, the shallow preCenozoic rocks beneath the southern part of Adrian Valley may restrict groundwater flow from Mason Valley into Adrian Valley. The saturated rocks and sediments of Tertiary age through which groundwater may flow from Churchill Canyon toward the Carson River, however, may be about 1,000 ft thick beneath the northern part of Adrian Valley.

Near the boundaries of the Stagecoach subbasin, the top of pre-Cenozoic rocks is from 1,000 to 4,000 ft lower than water-level altitudes (ㅍg. 6). Beneath the divide between Stagecoach Valley and northwestern Churchill Valley, groundwater may flow through about $1,000 \mathrm{ft}$ of Tertiary rocks and sediments and Quaternary basin-fill sediments. The divide between the southeastern part of the Stagecoach subbasin and the Bull Canyon subbasin is underlain by more than $4,000 \mathrm{ft}$ of Tertiary rocks and sediments and Quaternary basin-fill sediments. Tertiary rocks and sediments are about $1,000 \mathrm{ft}$ thick beneath the divide between the southwestern part of the Stagecoach subbasin and the western part of the Bull Canyon subbasin.

\section{Groundwater and Surface-Water Interactions}

The hydraulic connection and interactions between groundwater and surface-water systems are most evident when rivers gain or lose streamflow. Rivers commonly gain flow in a downstream direction where groundwater levels adjacent to the river are higher than the stage of the river and groundwater seeps from the aquifer into the river channel. Conversely, rivers lose flow where groundwater levels adjacent to the river are lower than the stage of the river and surface water infiltrates through the river channel into the aquifer.

\section{Findings in Previous Studies}

Data collected and discussed in previous studies provide estimates of the locations and volumes of streamflow gains and losses in the middle Carson River basin. Data used for such estimates include streamflow recorded at USGS gaging stations, sets of streamflow measurements (seepage measurements or "runs") made in channel reaches between the gaging stations, differences between the stage of the Carson River and the altitude of adjacent groundwater levels, and the chemical characteristics of the stream and groundwater.

Maurer and others (2009, p. 42-62) made estimates of streamflow gains and losses through the valleys of the Middle Carson River basin for selected periods on the basis of differences in mean annual, mean monthly, and mean daily inflow and outflow recorded at USGS streamflow-gaging stations near the boundaries of the valleys (fig. 2). Annual differences in streamflow through the entire Dayton Valley Hydrographic Area indicated an average long-term loss of 7,000 acre-ft for the period from 1971 to 2000, increasing to 16,000 acre-ft during dry years from 2002 to 2004, and average gains of about 19,000 acre-ft during wet years from 1995 to 1997 (Maurer and others, 2009, p. 58). The losses were the consequence of consumptive use of streamflow by irrigated crops and infiltration of streamflow to groundwater storage. The gains were caused by groundwater seepage to the river channel following wet years.

Annual differences in streamflow through Churchill Valley indicated losses each year, with an average long-term loss of more than 53,000 acre-ft for the period from 1971 to 2000 , a greater loss of about 57,000 acre-ft during dry years from 2002 to 2004, and an even greater loss of more than 100,000 acre-ft during wet years from 1995 to 1997 (Maurer and others, 2009, p. 61). The losses were caused by the consumptive use of streamflow by irrigated crops and by native plants (such as willow and cottonwood trees) adjacent to the river, by infiltration of streamflow beneath the river channel and beneath Lahontan Reservoir, and by evaporation from Lahontan Reservoir. Losses to infiltration and evaporation from the reservoir are greater in wet years when the surface area of the reservoir is greater. 
A detailed discussion of streamflow gains and losses through the subbasins of Dayton Valley and the seasonal and annual variations of those gains and losses is provided by Maurer and others (2009, p. 41-64). The data show that streamflow gains and losses vary seasonally and between wet and dry years, indicating that groundwater and surfacewater interactions are complex. The recorded streamflow data provide only net volumes of gain or loss over the entire river reach between existing gages, however, and provide no information on how conditions may vary between the gaging stations.

Data on differences in measured streamflow at locations between gaging stations and on the comparisons between altitude of groundwater levels and adjacent stream stage were presented and discussed by Maurer (1997, p. 15-16) and Maurer and others (2009, p. 76-83). These estimates of gains and losses from streamflow measurements and from comparisons of groundwater altitudes to river stage are based on sparse data collected over short periods.

\section{Insights Gained by Analyses of Recent Data}

Analyses of data collected for this study provide additional information on groundwater and surface-water interactions in the middle Carson River basin. These data include seepage measurements made at 13 sites along the Carson River in Dayton and Churchill Valleys, and results of analyses of surface-water samples collected at the sites. In 2007 and 2008, Lyon County installed monitoring wells in the Carson Plains subbasin and measured water levels in the wells; those data were compiled and analyzed for this study. Water-level data for wells near Lahontan Reservoir have been collected in an ongoing program with the Carson Water Subconservancy District (CWSD) since 2005. In a related USGS study, which began in 2009 in cooperation with the Carson Water Subconservancy District, data applicable to groundwater and surface-water interactions were collected in Dayton and Churchill Valleys and analyzed for use in this study.

Seepage measurements generally were made during periods of low flow at 13 sites along the Carson River in Dayton and Churchill Valleys to estimate the approximate location and volumes of streamflow gains and losses (fig. 15, table 4). Streamflow (also called discharge) measurements were made using standard USGS procedures and meters (Rantz, 1982). Measurements were made only once at sites 4 and 10 owing to problems with access. Stream water temperatures were recorded during all flow measurements and water samples collected during some of the measurement sets were analyzed for specific conductance and concentrations of deuterium.

The use of seepage measurements to calculate streamflow gains and losses requires the accounting for, and the measurement of, all diversions of flow and all tributary inflow above the measurement point, including any return flow from diversions. Tributary inflow to the Riverview subbasin from Eagle Valley Creek used in the calculations was the daily mean recorded flow (as noted on table 5), and was included with inflow to the reach measured at site 1 . On one occasion, tributary inflow from Eldorado Canyon (fig. 15, left-center of the map) was taking place and the measured flow of the tributary was included with flow of Carson River at site 6 for calculations.

Diversions for irrigation between the streamflow measurement sites are a potential source of water loss by infiltration through the ditch bed or irrigated fields and evapotranspiration from irrigated crops. Return flows from diversions generally re-enter the river upstream from the measurement sites. Diversions for irrigation to Mexican Ditch were measured and are included in table 5 for comparison with measured flow losses. Return flow from diversions upstream from site 6 was not measured but re-enter the river upstream from the site. Flow in the Baroni ditch (site 5), adjacent to site 6 , was measured and added to flow at site 6 for calculating gains and losses. Return flows from diversions downstream from site 6 re-enter the river upstream from site 7 , and diversions to the ditch near site 8 generally were not taking place during measurements, or were small enough to be considered negligible. Return flow from the ditch between sites 9 and 11 re-enters the river upstream from site 11, and diversions to the Buckland Ditch (site 10) were measured and added to flow at site 11 for calculations.

The accuracy of the individual measurements compared to the total flow and the calculated differences in flow also affected estimates of gains and losses. The individual measurements were generally rated "good” to "fair”, which indicates they are thought to be accurate to within 5 to 8 percent of the true flow, respectively. On the basis of the rules of error propagation, the calculated differences in flow should be greater than 7 to 11 percent of the total flow to ensure the flow differences are real and not an artifact of measurement error (Lebaugh and, Rosenberry 2008, p. 17).

Other complications in calculating gains and losses from streamflow measurements include short-term variations in flow and the travel time of water between measurement sites. Measurements were made by three teams with measurement times at the sites differing from 1 to 3 hours. With the exception of measurements made in March and April 2008, flow recorded at the streamflow-gaging stations was steady prior to, and during the days of measurement, with water stages varying less than $0.02 \mathrm{ft}$. The travel time for peak flows between sites 1 and 12 is about 1 day based on an analysis of station data. Measurements in March 2008 were made during a period of rising flow whereas those in April 2008 were made during a period of falling flow. The calculated losses in flow in March 2008 and gains calculated in April 2008 may be, in large part, affected by changes in flow during the measurements and the travel time between the measurement sites. 


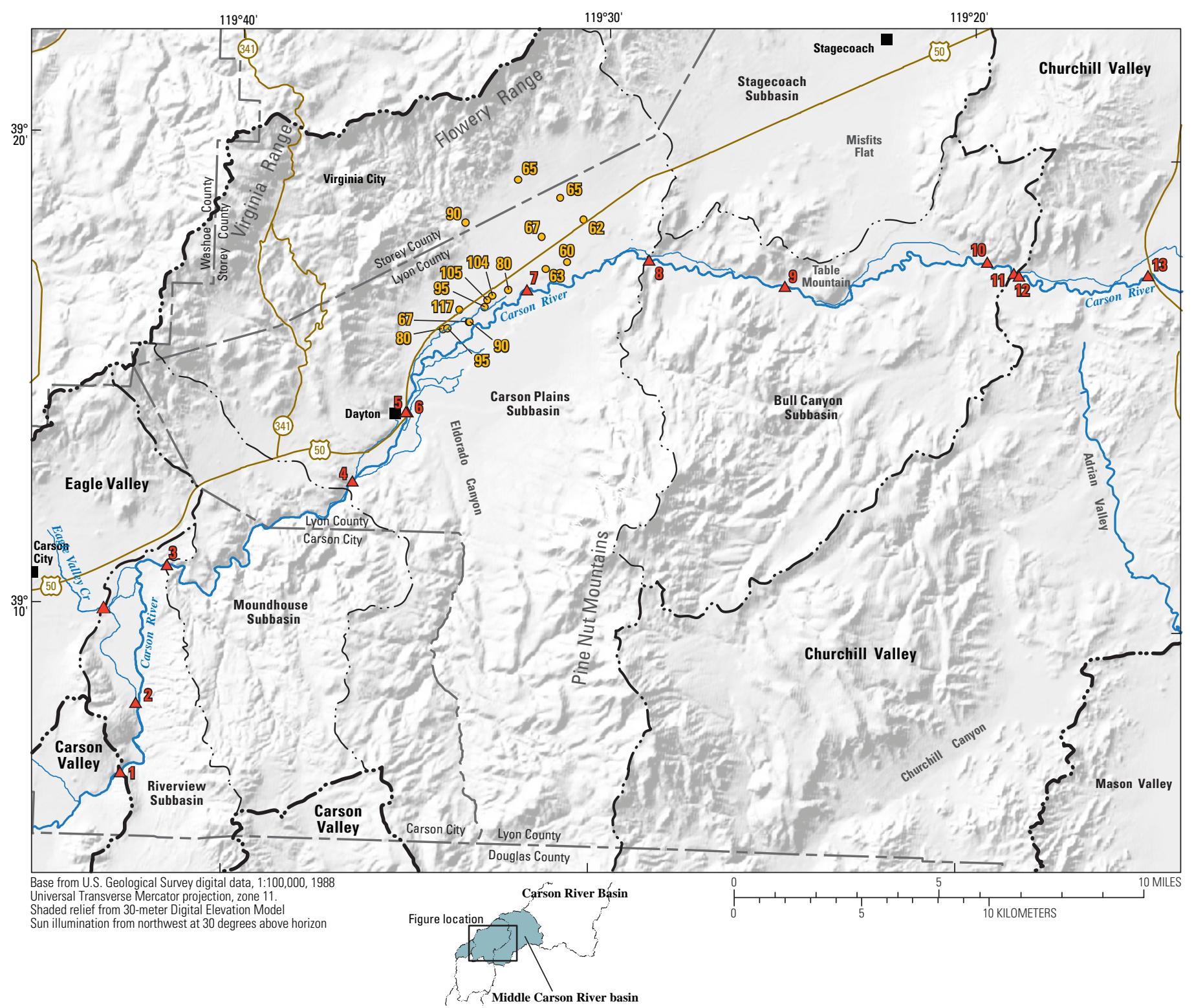

EXPLANATION

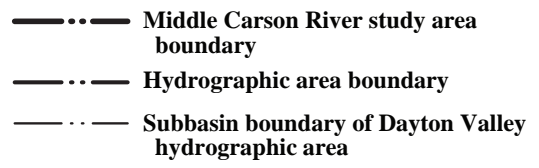

ป17 0 Well with warm water, number is temperature in degrees $F$

g. Seepage measurement site, number is site number, tables 3 and 4.

Figure 15. Location of seepage measurement sites and location of wells with warm water in the Carson Plains subbasin, middle Carson River basin, Nevada. 
Table 4. Location of seepage measurement sites, Middle Carson River, Nevada.

[See figure 15 for locations. Decimal latitude and longitude: North American Datum of 1983]

\begin{tabular}{lcccc}
\hline \multicolumn{1}{c}{ Site name } & $\begin{array}{c}\text { Station } \\
\text { No. }\end{array}$ & $\begin{array}{c}\text { Station } \\
\text { identification } \\
\text { No. }\end{array}$ & $\begin{array}{c}\text { Decimal } \\
\text { latitude }\end{array}$ & $\begin{array}{c}\text { Decimal } \\
\text { longitude }\end{array}$ \\
\hline Carson River near Carson City & 1 & 10311000 & 39.107687 & 119.713233 \\
Mexican Ditch near Silver Saddle Ranch & 2 & 10311025 & 39.132417 & 119.707111 \\
Carson River at Deer Run Road & 3 & 10311400 & 39.181378 & 119.694869 \\
Carson River near Winter Ranch & 4 & 10311600 & 39.21283 & 119.61159 \\
Baroni Ditch near Dayton & 5 & 10311655 & 39.237778 & 119.5875 \\
Carson River at Dayton & 6 & 10311700 & 39.237794 & 119.58786 \\
Carson River below Dayton & 7 & 10311715 & 39.28214 & 119.53462 \\
Carson River above Chaves Ranch & 8 & 10311850 & 39.29384 & 119.47961 \\
Carson River near Clifton & 9 & 10311875 & 39.28592 & 119.41749 \\
Carson River above Buckland Ditch & 10 & 10311895 & 39.29623 & 119.32577 \\
Buckland Ditch near Fort Churchill & 11 & 10311900 & 39.29256 & 119.31349 \\
Carson River near Fort Churchill & 12 & 10312000 & 39.29167 & 119.31111 \\
Carson River near Silver Springs & 13 & 10312020 & 39.29297 & 119.25238 \\
\hline
\end{tabular}

Differences in streamflow calculated from the remaining seepage measurements indicate consistent losses in flow in the Riverview subbasin. Streamflow is likely being lost to infiltration through the river channel between sites 1 and 3 on dates when the calculated loss is greater than diversions to the Mexican Ditch (table 5).

The measurements show varying streamflow gains and losses in the Moundhouse subbasin and streamflow gains in the eastern part of the Carson Plains subbasin. A gain was calculated through the Moundhouse subbasin on the single occasion when a measurement was made at site 4 , with gains between sites 3 and 6 on April 25, 2008, October 1, 2008, and October 1, 2009. It is uncertain if the gains took place solely within the Moundhouse subbasin, or if part of the gain was from the westernmost part of the Carson Plains subbasin between sites 4 and 6 . Streamflow gains generally were calculated on the eastern side of the Carson Plains subbasin between sites 6 and 7 and sites 7 and 8 , with the exception of October 25, 2007, and November 12, 2008, when losses between sites 6 and 7 were likely caused by diversions between the sites. The gain between sites 7 and 8 on November 12, 2008, is only 5 percent of the total flow and may not be real.

Measurements show that streamflow was usually being lost in the Bull Canyon subbasin downstream from site 8, except that gains were calculated between sites 6 and 12 on April 25, 2008, between sites 12 and 13 on November 12, 2008, and between sites 8 and 9 on August 25, 2009. The gains on April 25, 2008, and November 12, 2008, are 7 and 5 percent of the total flow, respectively, and may not be real.

The locations of gains and losses in streamflow calculated from the seepage measurements are in general agreement with findings in previous studies, with the exception of the eastern side of the Carson Plains subbasin, where gains were calculated in this study. Streamflow gains in the eastern part of the Carson Plains subbasin may result, in part, from inflow of groundwater from the Virginia Range to the northern side of the Carson River. Groundwater temperatures reported on driller's logs for wells north of the river range from 60 to $105^{\circ} \mathrm{F}$ (fig. 15). In mine shafts as deep as 3,000 ft near Virginia City, air temperatures as great as $150^{\circ} \mathrm{F}$ and springs discharging water as warm as $157^{\circ} \mathrm{F}$ have been reported (Schamberger, 1972, p. 39). The movement of such hot water toward the floor of the Carson Plains subbasin along deep flow paths may cause the warm water temperatures in wells north of the river. However, variations in stream temperature recorded during seepage measurements do not show a marked increase among sites 6, 7, and 8 . Any change in stream temperature caused by seepage of warm water through the river channel likely was masked by diurnal temperature variations in streamflow during the period of measurements.

The specific conductance of streamflow samples showed increases between sites 6 and 7 during some of the measurements, which could indicate groundwater seepage to the river channel. Specific conductance increased from about $600 \mu \mathrm{S} / \mathrm{cm}$ at site 6 to about $800 \mu \mathrm{S} / \mathrm{cm}$ at site 7 on October. 25, 2007, and October 1, 2008, then decreased to about $600 \mu \mathrm{S} / \mathrm{cm}$ at site 8 (table 6). Similarly, conductance increased from about $500 \mu \mathrm{S} / \mathrm{cm}$ at site 6 to 600 and $700 \mu \mathrm{S} /$ cm at site 7 on August 25, 2009, and October 1, 2009, respectively, with little change in conductance at site 8 . Historical data on the specific conductance of groundwater near the river in the Carson Plains subbasin show values ranging from about 500 to $1,400 \mu \mathrm{S} / \mathrm{cm}$. 
Table 5. Seepage measurements and calculated gains and losses.

[All flow values are in cubic feet per second. Site numbers are shown in figure 15. Gains and losses calculated by subtracting downstream flow from upstream flow and combining flow at sites 5 and 6 and sites 11 and 12 for calculations. Flow gains are positive values, flow losses are negative values. A bbreviations: $\mathrm{ft}^{3} / \mathrm{s}$, cubic foot per second; -, no measurement]

\begin{tabular}{|c|c|c|c|c|c|c|c|c|c|c|c|c|c|}
\hline Site name & $\begin{array}{c}\text { Carson } \\
\text { River } \\
\text { near } \\
\text { Carson } \\
\text { City }{ }^{1}\end{array}$ & $\begin{array}{c}\text { Mexican Ditch } \\
\text { near Silver Saddle } \\
\text { Ranch }^{2}\end{array}$ & $\begin{array}{l}\text { Carson } \\
\text { River at } \\
\text { Deer Run } \\
\text { Road }\end{array}$ & $\begin{array}{l}\text { Carson } \\
\text { River near } \\
\text { Winter } \\
\text { Ranch }\end{array}$ & $\begin{array}{l}\text { Baroni } \\
\text { Ditch } \\
\text { near } \\
\text { Dayton }\end{array}$ & $\begin{array}{l}\text { Carson } \\
\text { River at } \\
\text { Dayton }^{3}\end{array}$ & $\begin{array}{l}\text { Carson } \\
\text { River } \\
\text { below } \\
\text { Dayton }\end{array}$ & $\begin{array}{c}\text { Carson } \\
\text { River } \\
\text { above } \\
\text { Chaves } \\
\text { Ranch }\end{array}$ & $\begin{array}{l}\text { Carson } \\
\text { River } \\
\text { near } \\
\text { Clifton }\end{array}$ & $\begin{array}{c}\text { Carson } \\
\text { River } \\
\text { above } \\
\text { Buckland } \\
\text { Ditch }\end{array}$ & $\begin{array}{l}\text { Buckland } \\
\text { Ditch } \\
\text { near Fort } \\
\text { Churchill }\end{array}$ & $\begin{array}{c}\text { Carson } \\
\text { River } \\
\text { near Fort } \\
\text { Churchill }\end{array}$ & $\begin{array}{c}\text { Carson } \\
\text { River } \\
\text { near } \\
\text { Silver } \\
\text { Springs }\end{array}$ \\
\hline Site No. & 1 & 2 & 3 & 4 & 5 & 6 & 7 & 8 & 9 & 10 & 11 & 12 & 13 \\
\hline Date & Flow & Flow & Flow & Flow & Flow & Flow & Flow & Flow & Flow & Flow & Flow & Flow & Flow \\
\hline${ }^{4} 03-14-08$ & 332 & 1.9 & 274 & - & .33 & 237 & - & - & - & - & 5.4 & 217 & - \\
\hline Gain/L oss & & & -58.0 & & & -36.7 & & & & & & -14.9 & \\
\hline${ }^{5} 04-25-08$ & 103 & 25.2 & 91.7 & - & 13 & 95.4 & - & - & - & - & 28.1 & 86 & - \\
\hline Gain/L oss & & & -11.3 & & & 16.7 & & & & & & ${ }^{6} 5.7$ & \\
\hline $10-01-08$ & 4.9 & 0 & 0 & - & 0 & .04 & 1.4 & 3.5 & 2.8 & - & .0 & .1 & 0 \\
\hline Gain/L oss & & & -4.9 & & & .04 & 1.3 & 2.2 & -.7 & & & -2.7 & -.1 \\
\hline $10-01-09$ & 6.4 & 1.5 & .1 & - & .0 & .2 & 2.2 & 4.9 & 4.4 & - & 1.7 & .2 & - \\
\hline G ain/L oss & & & -6.3 & & & .1 & 2.0 & 2.7 & -.4 & & & -2.4 & \\
\hline
\end{tabular}

${ }^{1}$ Includes daily mean inflow from Eagle Valley Creek in cubic feet per second: 0.6 on 10-25-07, 2.1 on 03-14-08, 0.8 on 04-25-08, 0 on 10-01-08, 1.1 on 11-12-08, 0.12 on 08-25-09, 0 on 10-01-09

\footnotetext{
${ }^{2}$ Not included in gain/loss calculations; presented for comparison with calculated losses.

${ }^{3}$ Includes tributary inflow of $2.9 \mathrm{ft}^{3} / \mathrm{s}$ from Eldorado Canyon on 03-14-08.

${ }^{4}$ Calculated losses may, in large part, be the result of rising flow conditions this day.

${ }^{5}$ Calculated gains may, in large part, be the result of declining flow conditions this day.

${ }^{6}$ Calculated gain may be artifact of measurement error.
}

Table 6. Specific conductance and deuterium concentration of streamflow sampled during selected seepage measurements.

[All specific conductance values are in microsiemens per centimeter. All deuterium values are in parts per thousand. Site numbers are shown in figure 15. Gains and losses calculated by subtracting downstream flow from upstream flow and combining flow at sites 5 and 6 and sites 11 and 12 for calculations. Flow gains are positive values, flow losses are negative values. Abbreviations: SC, specific conductance; ${ }^{2} \mathrm{H}$, deuterium; permil, parts per thousand; -, no measurement]

\begin{tabular}{|c|c|c|c|c|c|c|c|c|c|c|c|c|}
\hline $\begin{array}{c}\text { Site } \\
\text { name }\end{array}$ & $\begin{array}{c}\text { Carson } \\
\text { River near } \\
\text { Carson } \\
\text { City }\end{array}$ & $\begin{array}{c}\text { Mexican } \\
\text { Ditch near } \\
\text { Silver Saddle } \\
\text { Ranch }\end{array}$ & $\begin{array}{c}\text { Carson } \\
\text { River at } \\
\text { Deer Run } \\
\text { Road }\end{array}$ & $\begin{array}{c}\text { Carson } \\
\text { River near } \\
\text { Winter } \\
\text { Ranch }\end{array}$ & $\begin{array}{c}\text { Baroni } \\
\text { Ditch near } \\
\text { Dayton }\end{array}$ & $\begin{array}{c}\text { Carson } \\
\text { River at } \\
\text { Dayton }\end{array}$ & $\begin{array}{c}\text { Carson } \\
\text { River } \\
\text { below } \\
\text { Dayton }\end{array}$ & $\begin{array}{c}\text { Carson } \\
\text { River above } \\
\text { Chaves } \\
\text { Ranch }\end{array}$ & $\begin{array}{c}\text { Carson } \\
\text { River near } \\
\text { Clifton }\end{array}$ & $\begin{array}{c}\text { Carson } \\
\text { River above } \\
\text { Buckland } \\
\text { Ditch }\end{array}$ & $\begin{array}{c}\text { Buckland } \\
\text { Ditch } \\
\text { near Fort } \\
\text { Churchill }\end{array}$ & $\begin{array}{c}\text { Carson } \\
\text { River } \\
\text { near Fort } \\
\text { Churchill }\end{array}$ \\
\hline Site No. & 1 & 2 & 3 & 4 & 5 & 6 & 7 & 8 & 9 & 10 & 11 & 12 \\
\hline Date & SC & SC & SC & SC & SC & SC & SC & SC & SC & SC & SC & SC \\
\hline $10-25-07$ & 500 & - & 570 & 590 & - & 620 & 810 & 650 & 620 & 670 & - & - \\
\hline${ }^{2} \mathrm{H}$ & - & - & - & - & - & - & - & - & - & - & - & - \\
\hline $11-12-08$ & - & - & 300 & - & - & 300 & 330 & 370 & 370 & - & - & 390 \\
\hline${ }^{2} \mathrm{H}$ & - & - & - & - & - & - & - & - & - & - & - & - \\
\hline 08-25-09 & 560 & 590 & 590 & - & 530 & 530 & 600 & 600 & 540 & - & - & 540 \\
\hline${ }^{2} \mathrm{H}$ & - & - & - & - & - & -99 & -102 & -106 & -103 & - & - & -99 \\
\hline 10-01-09 & 620 & 730 & 880 & - & - & 540 & 680 & 590 & 570 & - & - & 550 \\
\hline
\end{tabular}


Results of analyses for deuterium in samples of streamflow collected during selected seepage measurements indicate groundwater inflow to the channel of the Carson River in the Moundhouse subbasin and on the eastern side of the Carson Plains subbasin. The samples were collected during the August 25 and October 1, 2008, following USGS field methods (U.S. Geological Survey, 2007) and analyzed at the USGS Reston Stable Isotope Laboratory. The lab reports uncertainties of $2 \%$ (permil) for the deuterium measurements.

The concentrations of the stable, non-radioactive isotopes of hydrogen and oxygen in water may be used to evaluate the sources, movement, and mixing of water masses. Water molecules contain deuterium $\left({ }^{2} \mathrm{H}\right)$ and oxygen-18 $\left({ }^{18} \mathrm{O}\right)$ in various concentrations, which are not changed by most geochemical reactions and are affected only by evaporation and reactions with rocks in geothermal systems. Deuterium concentration is expressed relative to hydrogen- $1\left({ }^{2} \mathrm{H} /{ }^{1} \mathrm{H}\right)$ and reported as delta deuterium $(\delta \mathrm{D})$ relative to Vienna Standard Mean Ocean Water in parts per thousand (permil; Fritz and Fontes, 1980). Evaporation produces water that is heavier (less negative) in $\delta \mathrm{D}$ than the original water. Streamflow of the Carson River is the source of the "heaviest" water in the study area, with a deuterium concentration generally reported to range from -108 to -103 permil (Thomas and Lawrence, 1994, p. 15). The deuterium concentrations in groundwater samples distant from the river are more negative (the water is lighter), and range from -121 to -115 permil.

Variations in the deuterium concentration of stream water between measurement sites are consistent with the measured gains and losses in streamflow and variations in specific conductance. The deuterium concentration changes from less negative to more negative where groundwater with a more negative deuterium concentration seeps into the river channel between the sampling sites (fig. 16). Carson River streamflow sampled from site 3 (fig. 15) in the Riverview subbasin on October 1, 2009, had a deuterium concentration of -84 permil, significantly less negative than in groundwater adjacent to the river. Seepage of isotopically more negative groundwater into the river channel likely caused the deuterium concentration of streamflow to become more negative in the Moundhouse and Carson Plains subbasins between measurement site 3 (-84 permil) and site 8 (average of -107 permil). Downstream from site 8 in the Bull Canyon subbasin, the deuterium concentration of the streamflow becomes less negative, likely the result of evaporation of streamflow between the sites. Inflow of groundwater to the river channel between sites 8 and 12 is not likely because the deuterium concentration of groundwater near the river generally is more negative than the streamflow, ranging from -105 to -113 permil.

Comparison of water-level fluctuations in monitoring wells installed near the Carson River and measured by Lyon County personnel (fig. 17) with variations in flow of the Carson River provide additional insight into groundwater and surface-water interactions in the Carson Plains subbasin. Water levels in wells close to the Carson River change quickly in response to changes in flow of the river recorded at the gaging station at Dayton (fig. 18A). Water levels at most wells show sharp peaks during spring runoff, coincident with the peak in river flow, and steep declines during early summer as river flow decreases. The coincident peaks indicate water lost to infiltration through the channel of the Carson River quickly recharges the adjacent aquifer. Water lost to infiltration through the beds of irrigation ditches and beneath irrigated fields (green areas in fig. 17) likely also contributes to groundwater recharge. Groundwater levels begin to rise in late autumn when flow of the river increases from near zero flow at the end of the irrigation season. Water-level rises in late autumn also may be caused by a decrease in groundwater pumping and a decrease in groundwater discharge to evapotranspiration that takes place in late autumn each year. Small variations in streamflow during winter months also cause peaks and declines in water levels at most wells. The variations show a close link between the surface-water and groundwater systems in the Carson Plains subbasin.

Water levels at wells 3 and 4 show differences in their response to pumping from a nearby municipal supply well (fig. 18A). Wells 3 and 4 are about $100 \mathrm{ft}$ east of a municipal supply well adjacent to the Carson River. Well 4 is a deep well screened from 145 to $165 \mathrm{ft}$ below land surface, similar to the supply well, which is screened from 100 to $190 \mathrm{ft}$ below land surface. Water levels in well 4 show declines during peak river flow when the municipal well begins pumping, and large water-level fluctuations when the well pump is turned on and off during summer months. Well 3 is a shallow well screened from 5 to $15 \mathrm{ft}$ below land surface that shows water-level peaks during spring runoff and only minor fluctuations when the supply well is turned on and off. When the supply well is not pumping, water levels at the two wells show similar variations, and the deeper water level at well 4 shows a downward vertical gradient. Driller's logs for the municipal supply well and monitoring well 4 describe sandy clay and silty clay layers from 120 to $130 \mathrm{ft}$ below land surface that likely dampens the response of the water level in well 3 to pumping at the municipal well.

Water lost to infiltration through the channel of the Carson River appears to affect water levels at least $1 \mathrm{mi}$ from the river. Water levels in wells more distant from the Carson River show relatively broad spring peaks that lag behind the peak in spring runoff by about 1 month (wells 8, 9, and 10; fig. 18B). Water lost to infiltration through the beds of irrigation ditches also may contribute to recharge in areas away from the river channel when diversion rates increase as the river stage increases during spring months (fig. 17). The water-level rise at well 8 from October 2008 to June 2009 may, in part, be caused by recharge from the nearby mountain block from winter precipitation, as suggested by the greater amplitude of water-level rise in that well than seen at wells 9 and 10 . Water-level peaks at wells 6 and 7 generally coincide more closely with the peaks during spring runoff or with smaller streamflow peaks during the winter. 


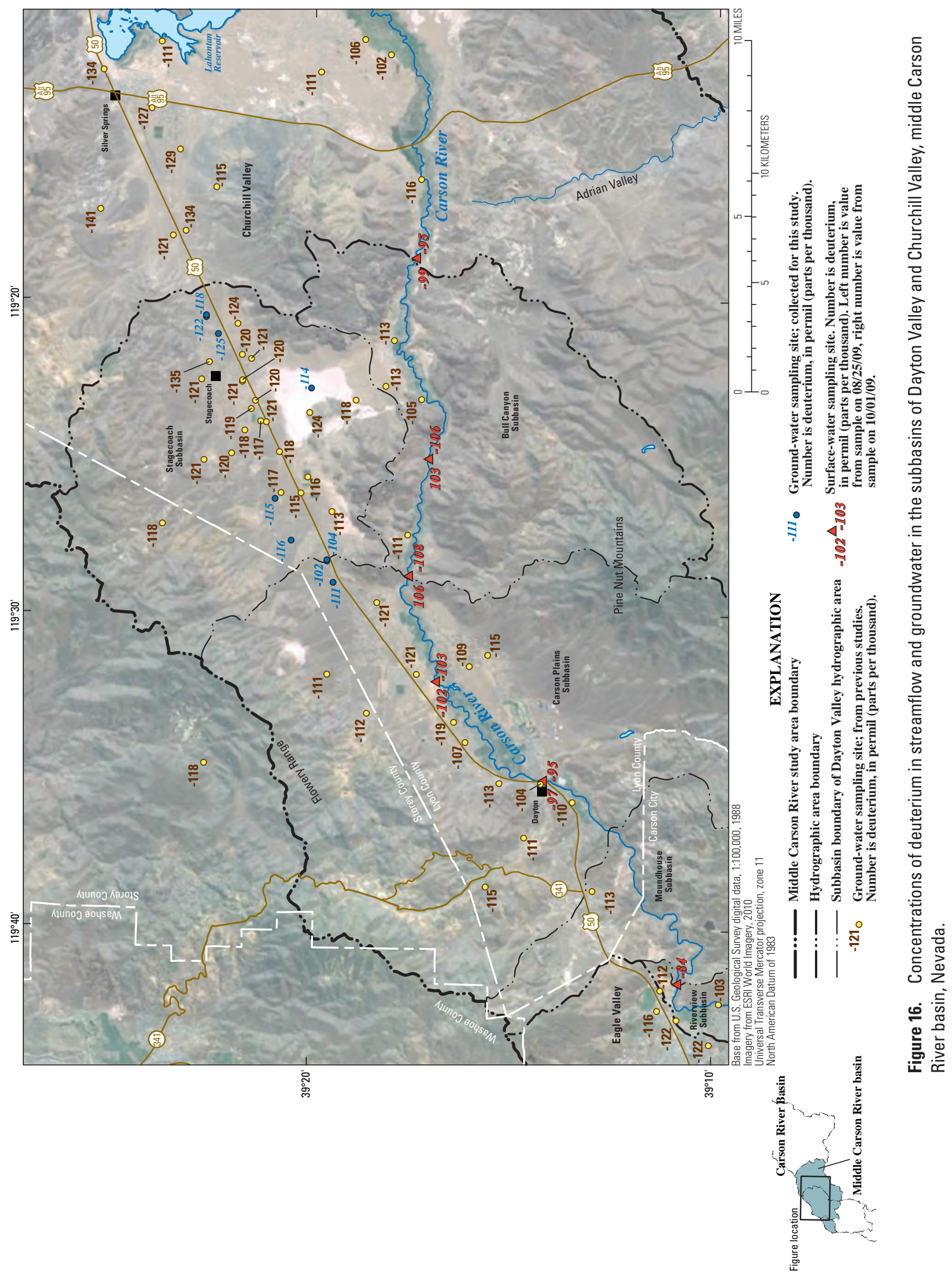




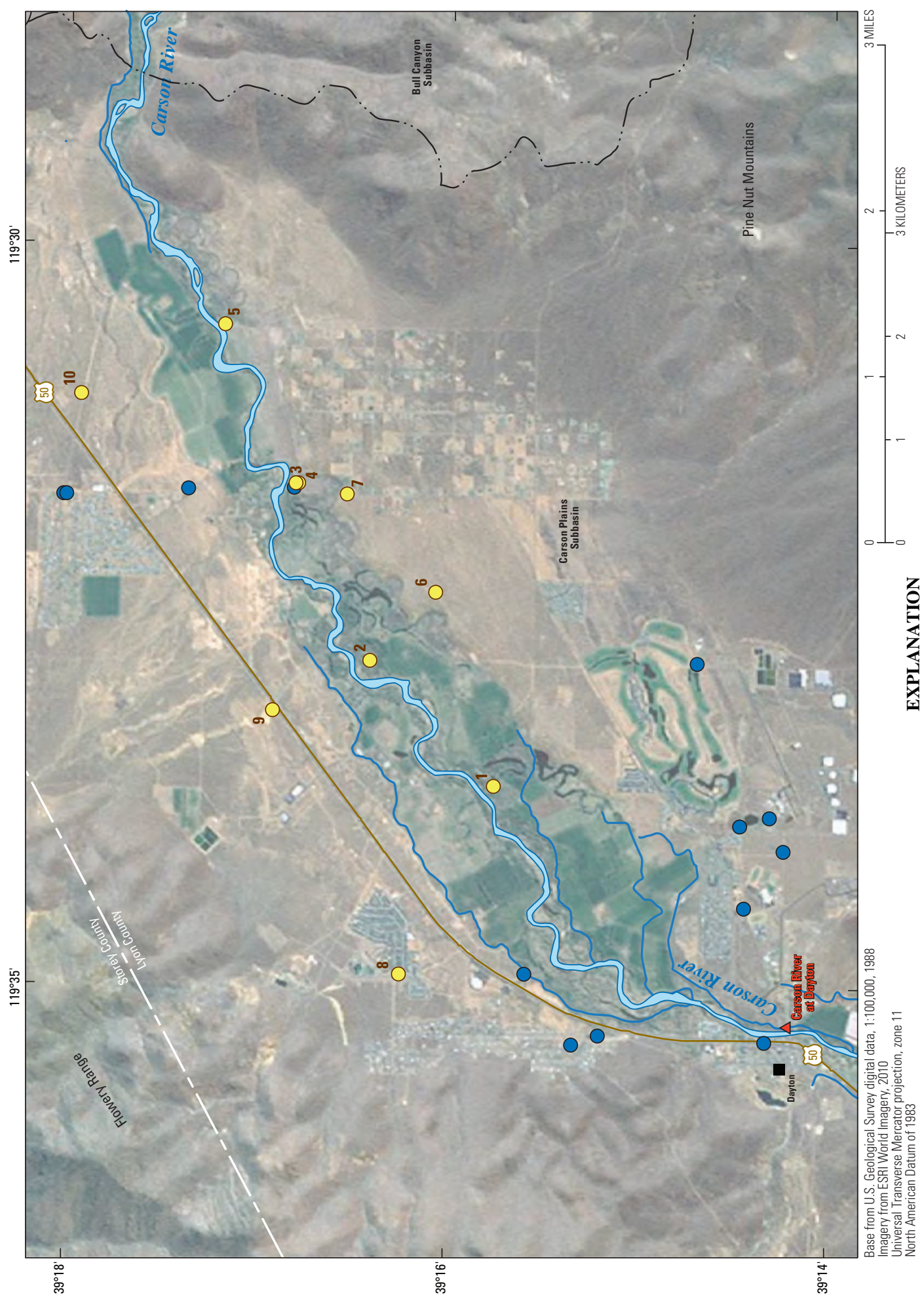

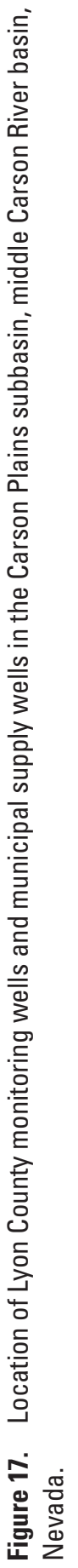



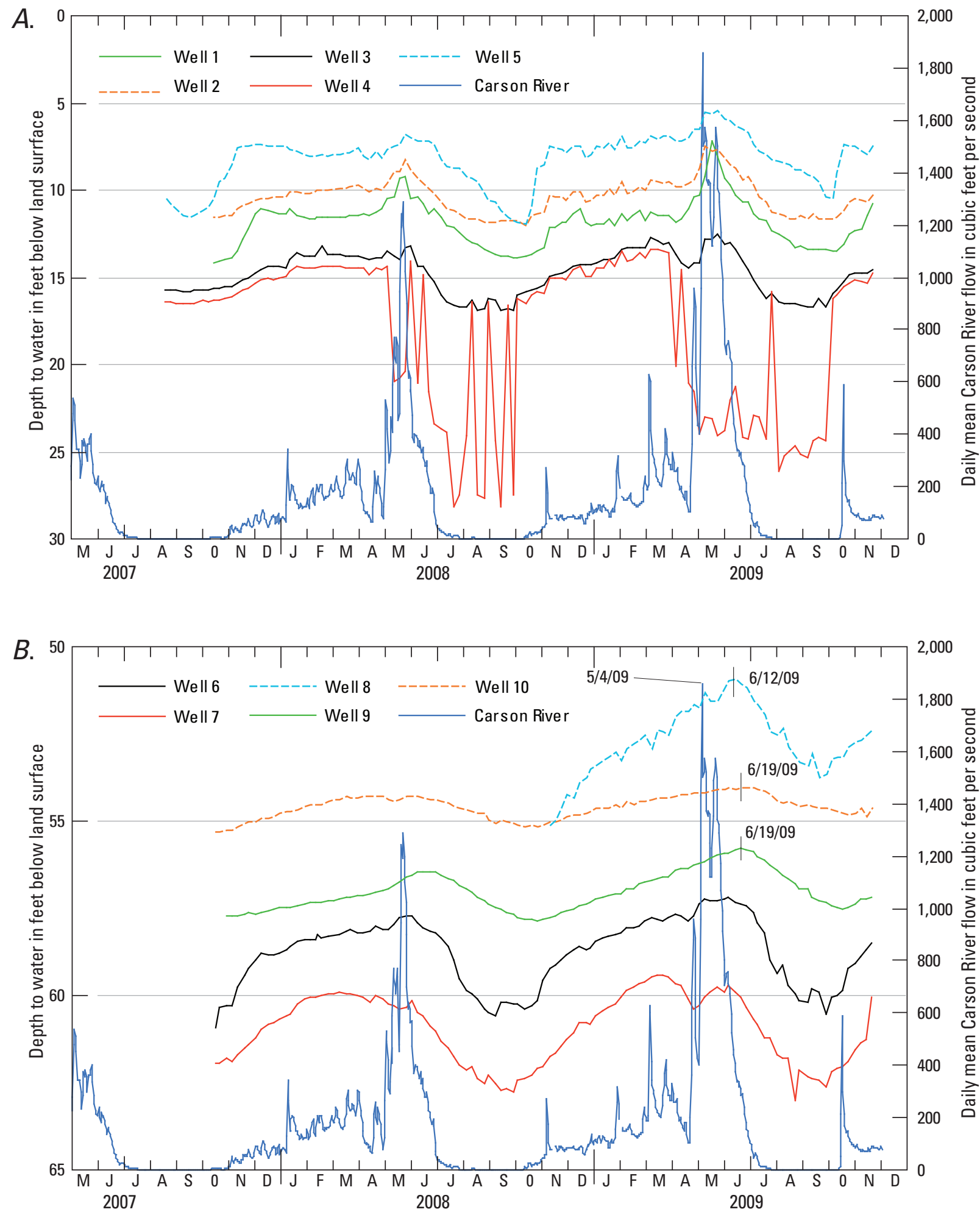

Figure 18. Variations in groundwater levels compared with variations in streamflow of the Carson River at Dayton for $(A)$ wells close to the Carson River, and $(B)$ wells distant from the Carson River, middle Carson River basin, Nevada. 
Water levels in wells near Lahontan Reservoir show losses of stored water to infiltration beneath the reservoir during periods of high reservoir stage, and groundwater seepage to the reservoir during periods of low stage. Waterlevel fluctuations in two wells (wells 1 and 2) screened in basin-fill sediments west of the reservoir vary with the altitude of daily mean reservoir stage, and in 2005 lagged behind peak reservoir stage by about 6 weeks (fig. 19; well locations on fig. 14D). However, the lag time is very approximate because the water levels were measured about monthly. Water levels in well 3 (fig. 19), screened in a mixture of basin-fill sediments and broken rock on the eastern side of the reservoir also lagged behind peak reservoir stage by about 6.5 weeks in 2009. This lag time is considered accurate because water levels at the well were recorded hourly. At peak reservoir levels, there is a vertical gradient from the surface water stored in the reservoir to aquifers surrounding the reservoir, and the gradient between wells 1 and 2 is westward. During periods of low reservoir stage and the entire year in 2008, the gradient is from the aquifers toward the reservoir and the gradient between wells 1 and 2 is eastward. In late October and early November 2008, groundwater seepage on the western side of Lahontan Reservoir was observed near Silver Springs filling the thalweg of the Carson River channel at a time when the channel of the Carson River upstream from the reservoir had been dry for several weeks (ig. 20A). Seepage took place by a combination of diffuse flow from a continuous seepage face (fig. 20B) and more concentrated flow producing individual seepage channels (fig. 20C).

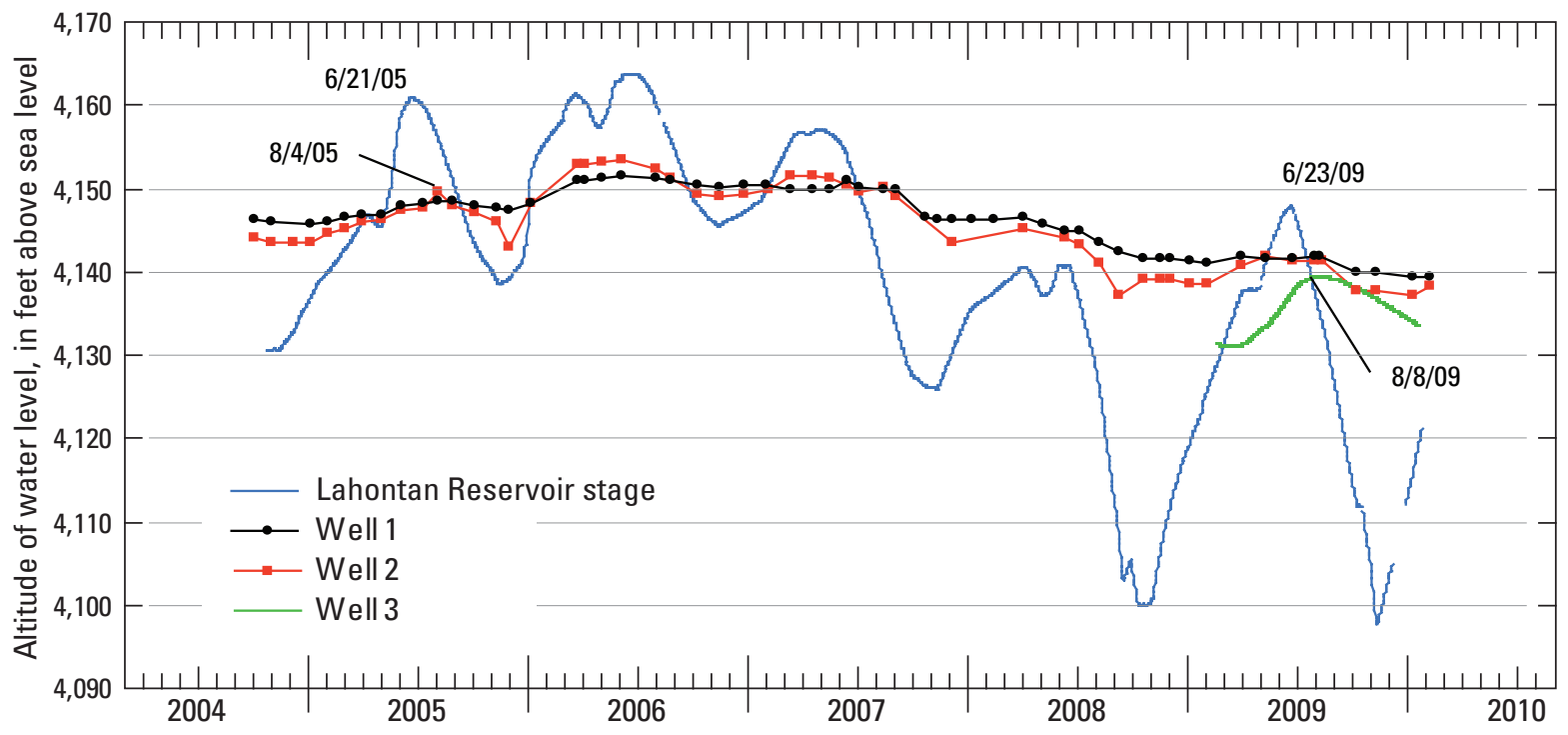

Figure 19. Variations in groundwater levels compared to variations of the stage of Lahontan Reservoir, middle Carson River basin, Nevada. Well locations shown in figure 14D. 


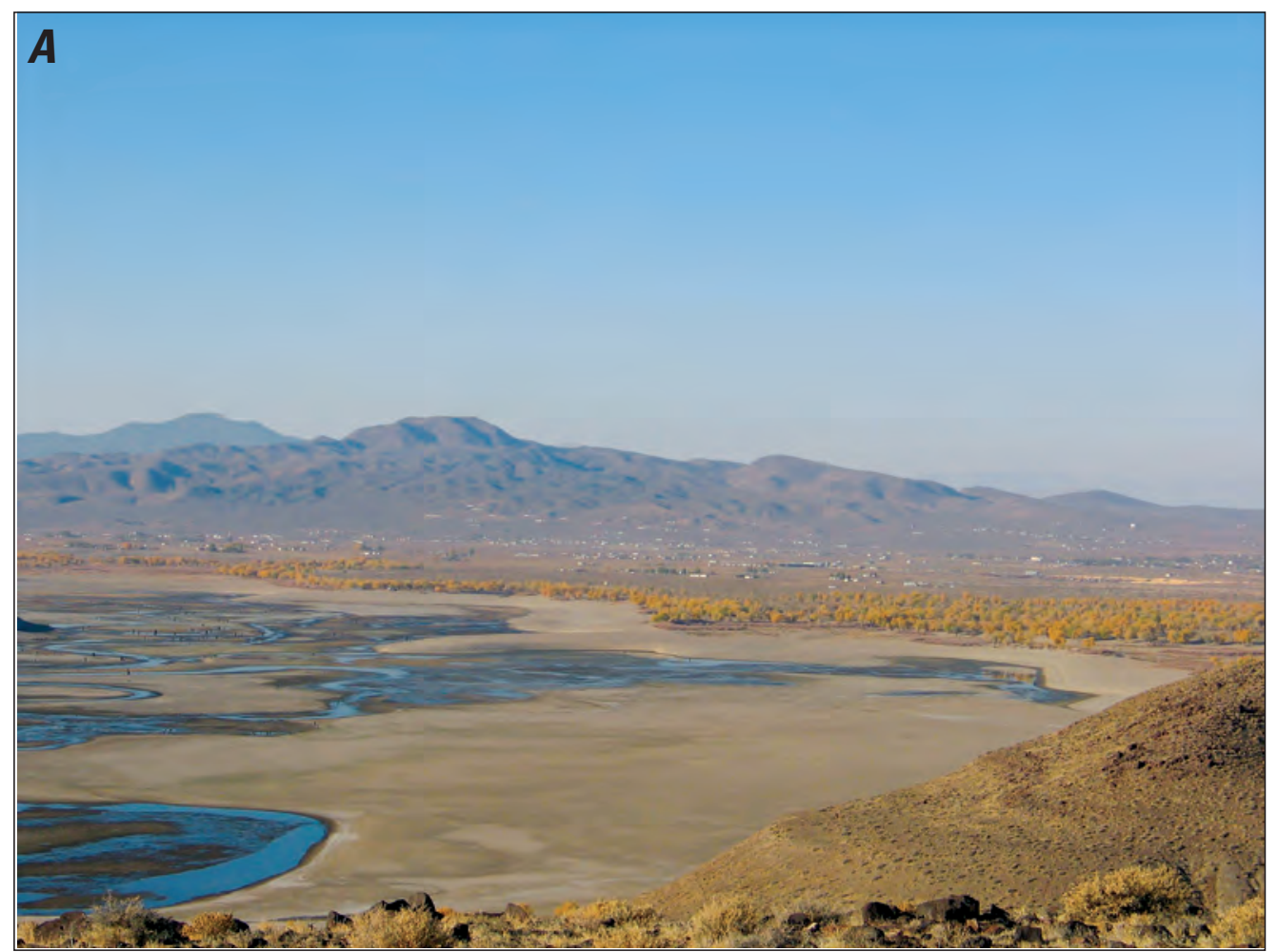

Figure 20. (A) Groundwater seepage east of Silver Springs, Nev, filling the thalweg of the Carson River channel on the floor of Lahontan Reservoir, looking west with Churchill Butte in the background, $(B)$ diffuse seepage through a continuous seepage face, and $(C)$ concentrated flow in an individual seepage channel, middle Carson River basin, Nevada. Photographs taken by author Oct. 29-Nov. 4, 2008.

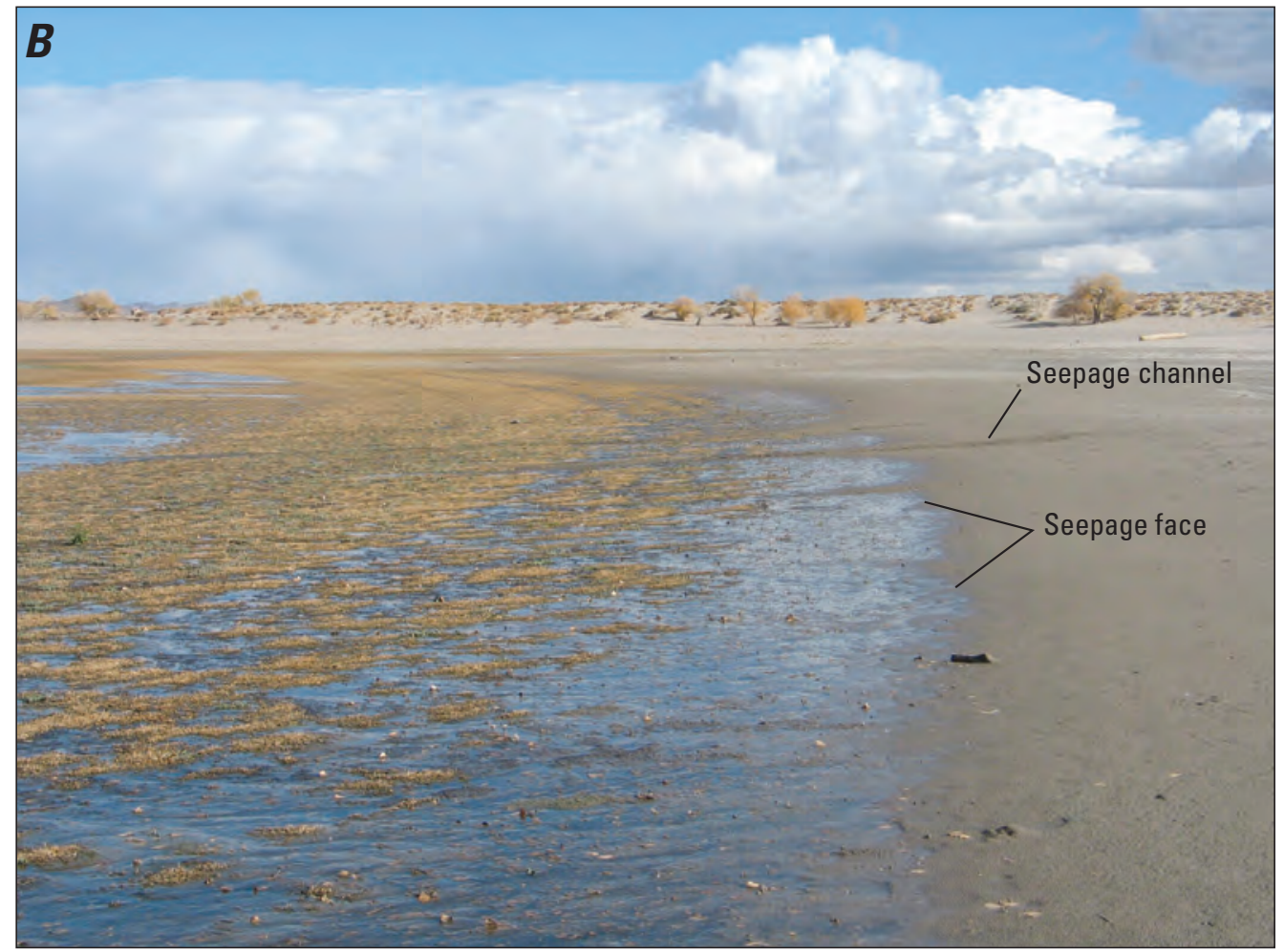

Figure 20.-Continued 


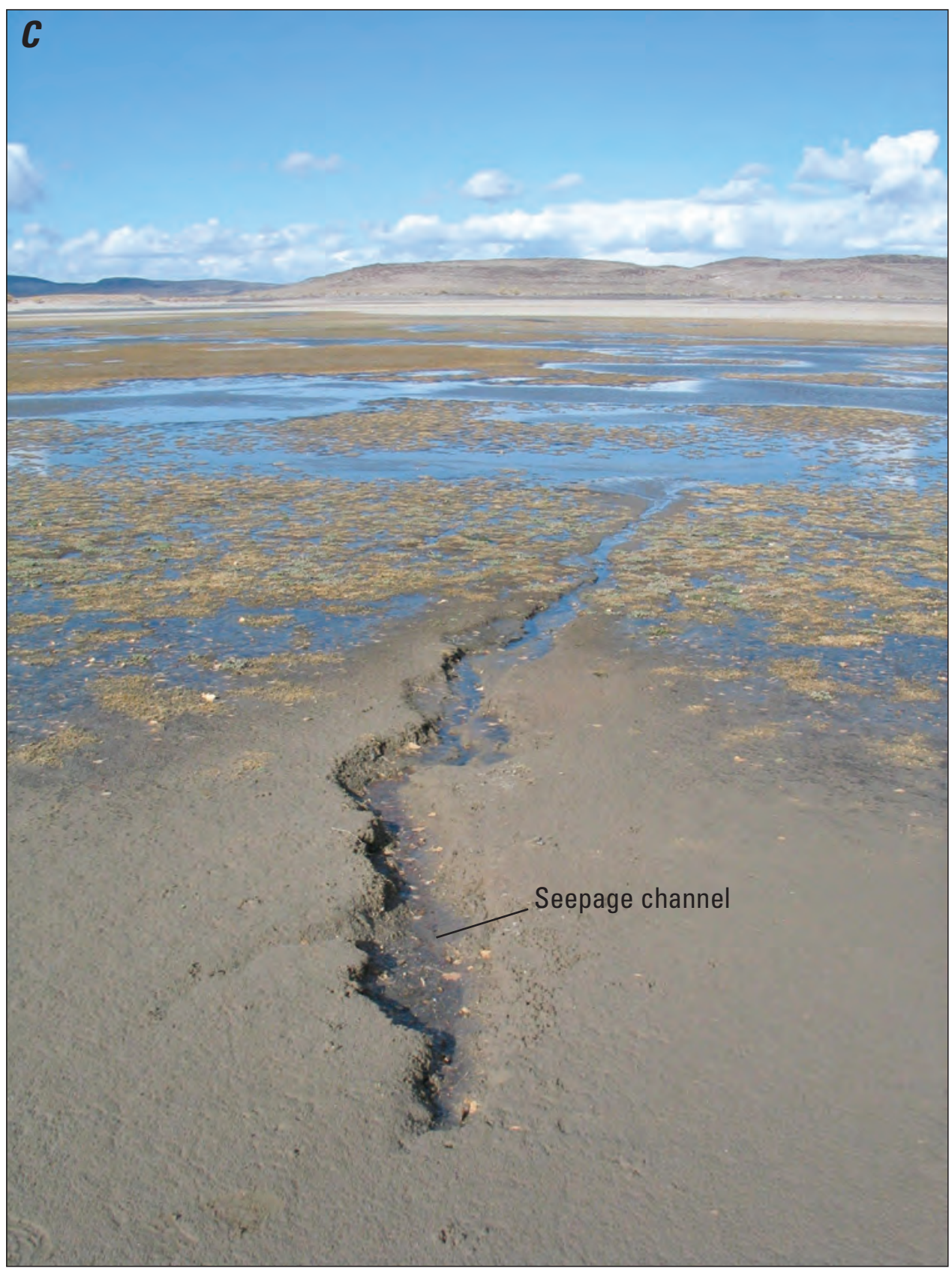

Figure 20.-Continued 


\section{Summary and Conclusions}

Changes in land use and water use and increasing development of water resources in the Carson River basin may affect flow of the river and, in turn, affect downstream water users dependent on sustained river flows to Lahontan Reservoir. To address these concerns, the U.S. Geological Survey, in cooperation with the Bureau of Reclamation, began a study in 2008 to evaluate groundwater flow in the Carson River basin between Carson Valley and Lahontan Dam, called the middle Carson River basin in this report. This report describes the geologic framework and hydrogeologic setting of the middle Carson River basin and presents information from which a numerical model of the groundwater and surface-water flow systems is currently being developed.

The middle Carson River basin includes the hydrographic areas of Eagle, Dayton, and Churchill Valleys upstream of Lahontan Dam. Data also were collected for this study in the western part of the Carson Desert hydrographic area, which encompasses Lahontan Valley. The Dayton Valley hydrographic area is divided into five subbasins; Riverview, Moundhouse, Carson Plains, Bull Canyon, and Stagecoach.

Hydrogeologic units in the middle Carson River basin were developed by grouping geologic units mapped at a scale of 1:100,000 into units assumed to have similar hydrologic characteristics. Consolidated rocks were grouped into granitic and metamorphic hydrogeologic units of pre-Cenozoic age that underlie the Tertiary and Quaternary hydrogeologic units in the valleys. Consolidated volcanic rocks were grouped into ash-flow tuffs, andesitic, basaltic and rhyolitic, and semiconsolidated sedimentary hydrogeologic units of Tertiary age. Various types of unconsolidated sediments of Quaternary age were grouped into a basin-fill hydrogeologic unit. Unconsolidated sediments described as thin veneers overlying other hydrogeologic units, and eolian sand deposits were distinguished from the basin-fill hydrogeologic unit.

The hydrogeologic units of consolidated rocks are much less permeable to groundwater flow than the basin-fill unit. However, numerous domestic wells have been installed in Tertiary volcanic rocks near the periphery of the Stagecoach subbasin and in Churchill Valley. Similarly, the Tertiary sedimentary hydrogeologic unit is likely also less permeable than the basin-fill unit, but domestic wells have been installed that likely pump water from the unit. The basin-fill hydrogeologic unit overlies the other hydrogeologic units and forms the principal aquifers in the study area.

The basin-fill hydrogeologic unit comprises unconsolidated sediments deposited by streams forming alluvial fans surrounding the valleys, fluvial sediments deposited by the Carson River and other streams, and lake sediments deposited during high stands of ancient Lake Lahontan. Sediments deposited by ancient Lake Lahontan are present in the basin-fill hydrogeologic unit from the Moundhouse subbasin eastward to Lahontan Valley. Lake
Lahontan covered much of northwestern Nevada at various times during the Pleistocene epoch and its level fluctuated in response to changing glacial climates. As the levels of ancient Lake Lahontan rose and fell, the deposition of deltaic sediments at the mouth of the Carson River moved upstream and downstream, and the deposition of beach sand and gravel, deep-lake silt and clay, and eolian sand moved laterally across the valley floors, creating a complex mixture of Quaternary sediments within the basin-fill hydrogeologic unit.

Lithologic descriptions from driller's logs show that coarse gravel and cobble layers are more than $300 \mathrm{ft}$ thick and as deep as $600 \mathrm{ft}$ below land surface in the Carson Plains subbasin. Thick clay layers also are found in the Carson Plains subbasin, sometimes in close proximity to wells having thick coarse gravel layers. Thick layers of coarse gravel and cobbles are found in the northern part of the Stagecoach subbasin, whereas thick clay layers are present in Churchill and Lahontan Valleys.

The thickness of the combined section of Tertiary volcanic and sedimentary rocks and Quaternary basin-fill deposits was previously estimated for northern Nevada using gravity data. In the study area, the estimated thickness of Tertiary and Quaternary rocks and sediments ranges from zero where pre-Cenozoic rocks are exposed to greater than $10,000 \mathrm{ft}$ in the Bull Canyon subbasin, and greater than 6,000 ft thick on the western side of Churchill Butte and beneath the Desert Mountains. The thickness of Quaternary basin-fill sediments was estimated using existing gravity data measured at 640 stations and gravity measurements made for the study at an additional 95 stations, along with lithologic descriptions from driller's logs for deep wells that did and did not penetrate consolidated rocks.

The resulting estimates of the thickness of unconsolidated basin-fill sediments generally are less than estimates in previous studies. In Carson Plains, basin-fill sediments are thickest, greater than 1,000 ft, about $4 \mathrm{mi}$ northeast of Dayton. In the Stagecoach subbasin, basin-fill sediments are thickest greater than $800 \mathrm{ft}$, beneath the western part of the subbasin, and are greater than $600 \mathrm{ft}$ thick beneath the northeastern part of the subbasin. In Churchill Valley, basin-fill sediments are thickest, greater than $1,000 \mathrm{ft}$, about $5 \mathrm{mi}$ west of Silver Springs, and greater than $800 \mathrm{ft}$ thick beneath the Carson River in the southern part of the valley. Basin-fill thickness is estimated to exceed 1,300 $\mathrm{ft}$ near the intersections of U.S. Highway 95 and U.S. Highway 50 in Lahontan Valley. Sediments, likely of Tertiary age, underlie consolidated rocks at several locations near the valley margins and may underlie unconsolidated basin-fill sediments at many locations in the study area, but are difficult to distinguish using gravity data. For this reason, estimates of the thickness of basin-fill sediments made for this study are considered to be minimum values representing the most permeable parts of the basin fill sediments. 
Estimates of the hydraulic conductivity of basin-fill sediments and consolidated rocks were made on the basis of analyses of slug test data collected at 30 monitoring wells in Dayton and Churchill Valleys. The slug test data indicate potential ranges of hydraulic conductivity in the various types of geologic materials; greater than $10 \mathrm{ft} / \mathrm{d}$ to more than $100 \mathrm{ft} / \mathrm{d}$ for fluvial sediments near the flood plain, less than $10 \mathrm{ft} / \mathrm{d}$ for basin-fill sediments outside the flood plain, and less than $1 \mathrm{ft} / \mathrm{d}$ for consolidated rocks. The estimates of hydraulic conductivity are likely representative of the upper $50 \mathrm{ft}$ of saturated basin-fill sediments

Single-well aquifer test data from 16 wells in Dayton Valley were analyzed to estimate the transmissivity of the entire thickness of basin-fill sediments. The estimates of transmissivity approached or exceeded 30,000 $\mathrm{ft}^{2} / \mathrm{d}$ near the Carson River flood plain in the Riverview and Carson Plains subbasins, and a value of $90,000 \mathrm{ft}^{2} / \mathrm{d}$ was simulated in a numerical flow model on the basis of data from a multiplewell aquifer test. The model simulation indicated that permeable gravel and cobble zones (described in lithologic logs for nearby wells) at depths greater than $400 \mathrm{ft}$ supplied water to the pumping well.

The distribution of transmissivity in Eagle, Dayton, Churchill, and western Lahontan Valleys was estimated using a log-based regression between specific capacity and transmissivity calculated from the 16 tests and information on well-yield and drawdown reported in about 400 driller's logs. The resulting distribution of transmissivity shows values exceeding 20,000 $\mathrm{ft}^{2} / \mathrm{d}$ generally are near the Carson River in Dayton, Churchill, and western Lahontan Valley. Transmissivity values greater than $20,000 \mathrm{ft}^{2} / \mathrm{d}$ are found north of Misfits Flat in the Stagecoach subbasin and values greater than $10,000 \mathrm{ft}^{2} / \mathrm{d}$ are found throughout the western part of Churchill Valley. The transmissivity estimates in the Stagecoach subbasin are somewhat greater than previous model-derived estimates, whereas the transmissivity estimates in Eagle Valley agree well with those determined previously.

The distribution of specific yield of previously mapped geologic units in the middle Carson River basin was estimated on the basis of their lithologic descriptions, and on values reported in the literature for units with similar lithology. The specific yield of consolidated rocks was estimated to be the lowest, ranging from less than 1 to 2 percent, with the exception of basaltic rocks which may have a specific yield as great as 15 percent where highly fractured and vesicular. The specific yield of sedimentary deposits was estimated to range from 1 to 40 percent, depending on grain size and sorting. The fine-grained semi-consolidated Tertiary sediments were assigned a range from 1 to 15 percent, alluvial fan sediments were assigned a range from 10 to 30 percent, lake deposits were assigned a range from 20 to 40 percent, and fluvial deposits were assigned a range from 30 to 40 percent.
Water-level measurements were made in April 2009 at about 300 wells, including 10 wells installed for this study, to develop updated contours of water-level altitude for each valley and to evaluate long-term water-level changes and regional groundwater-flow directions. Water levels from new wells on the topographic divide between the Carson Plains and Stagecoach subbasins show a distinct groundwater divide between the subbasins. Water levels from new wells on the northeastern side of the Stagecoach subbasin indicate flow northeastward into Churchill Valley, where previous studies reported a groundwater divide in 1971. Water levels have declined as much as $70 \mathrm{ft}$ since 1964 in the northwestern part of Eagle Valley, about $10 \mathrm{ft}$ since 1995 in a small area east of Dayton in the Carson Plains subbasin, about $5 \mathrm{ft}$ since 1982 over much of the valley floor in the Stagecoach subbasin, about $10 \mathrm{ft}$ since 1982 in the western and northeastern parts of the Stagecoach subbasin, and about $5 \mathrm{ft}$ since 1982 in the northwestern part of Churchill Valley. The declines are likely the result of pumping for municipal or agricultural use.

Groundwater-flow directions are uncertain beneath parts of the boundary of Churchill Valley. A comparison of the altitude of the top of pre-Cenozoic rocks with water-level altitudes was used to evaluate the potential for groundwater flow beneath the boundaries of Churchill Valley, assuming the rocks are relatively impermeable to groundwater flow. Relatively thick sections of saturated Tertiary rocks and sediments overlying the pre-Cenozoic rocks are present beneath the eastern part of the Desert Mountains, south of the Dead Camel Mountains, and beneath the northern part of Adrian Valley through which groundwater flow may take place. North of Lahontan Reservoir, beneath the Dead Camel Mountains, and beneath the southern part of Adrian Valley, the altitudes of pre-Cenozoic rocks are similar to or slightly less than water-level altitudes, indicating that interbasin groundwater flow does not take place or is small.

Data collected for this study from 2007 to 2009 on groundwater and surface-water interactions in the middle Carson River basin include streamflow measurements and surface-water quality samples at 13 sites along the Carson River in Dayton and Churchill Valleys, and measurements of groundwater levels in 10 wells in the Carson Plains subbasin and 3 wells in Churchill Valley. The water-level data were compared to variations in stage of the Carson River and Lahontan Reservoir. Differences in streamflow calculated from the measurements and variations in water quality indicate a loss of streamflow in the Riverview subbasin, streamflow gains in the Moundhouse subbasin and in the eastern part of the Carson Plains subbasin, and streamflow losses in the Bull Canyon subbasin.

Variations in groundwater levels and stream and reservoir stage in the Carson Plains subbasin and Churchill Valley indicate a close link between the surface-water and groundwater systems. In Carson Plains, water levels in 
monitoring wells close to the Carson River fluctuate quickly in response to changes in flow of the Carson River. Water levels in wells more distant from the Carson River show broad springtime peaks that lag behind the peak in spring runoff by about 1 month, indicating streamflow lost to infiltration affects water levels at least $1 \mathrm{mi}$ from the river. The fluctuations in groundwater levels caused by variations in stream stage indicate streamflow lost to infiltration through the channel of the Carson River, the beds of irrigation ditches, and beneath irrigated fields is a source of groundwater recharge. Near the Carson River, fluctuations in groundwater levels show the response to pumping from a municipal supply well is damped in the shallow part of the aquifer by silt and clay layers from 120 to $130 \mathrm{ft}$ below land surface. In Churchill Valley, water levels in wells near Lahontan Reservoir show losses to infiltration beneath the reservoir during periods of high reservoir stage, and groundwater seepage to the reservoir during periods of low stage.

\section{Acknowledgments}

The authors thank the many private well owners who allowed access to their property for water-level measurements and GPS surveys of their wells; the Nevada Division of Water Resources, Kelly Hale of Carson City Utilities Department, Gary Blackwelder and Scott Fleckenstein of Lyon County Utilities, Marlon Cook and Joseph Seng of Stagecoach General Improvement District, and Donald Allen of the Silver Springs Mutual Water Company for providing water-level data; and Tim Donahoe of TEC Engineering Consultants, Brad Hardt of Brown and Caldwell, Ryan Hoerth of Vidler Water Company, Rit Palmer and Mark Brethauer of Carson City Public Works, and Mike Workman and James Youngblood of Lyon County Utilities for providing well information and aquifer-test data.

\section{References Cited}

Adams, K.D., 2007, Late Holocene sedimentary environments and lake-level fluctuations at Walker Lake, Nevada, USA: Geological Society of America Bulletin, v. 119, no. 1-2, p. 126-139.

Aqua, 2007, Carson City production well no. 24B drilling, construction, and testing report: Aqua Hydrogeologic Consulting, Reno, Nev., May 2007, 18 p.

Aqua, 2010, Carson City well no. 41B, drilling, construction, and pumping test report: Aqua Hydrogeologic Consulting, Reno, Nev., June 2010, 19 p.
Arteaga, F.E., 1986, Mathematical model analysis of the Eagle Valley groundwater basin, west-central Nevada: Nevada Division of Water Resources, Bulletin 45, 53 p.

Arteaga, F.E., and Durbin, T.J., 1979, Development of a relation for steady-state pumping rate for Eagle Valley groundwater basin, Nevada: U.S. Geological Survey OpenFile Report 79-261, 44 p.

BAE SYSTEMS Advanced Technologies, Inc., 2004, Carson Valley Conservation District Hyperspectral and LiDAR imaging, Final Report, October 28, 2004: Washington DC, BAE SYSTEMS Advanced Technologies, Inc., 113 p.

Benson, L.V., 1991, Timing of the last high stand of Lake Lahontan: Journal of Paleolimnology, v. 5, p. 115-126.

Benson, L.V., and Thompson, R.S., 1987, Lake-level variation in the Lahontan Basin for the past 50,000 years: Quaternary Research, v. 28, p. 69-85.

Benson, L.V., Currey, D.R., Dorn, R.I., Lajoie, K.R., Oviatt, C.G., Robinson S.W., Smith, G.I., and Stine, S., 1990, Chronology of expansion and contraction of four Great Basin lake systems during the past 50,000 years: Paleogeography, Paleoclimatology, and Paleoecology, v. 78, p. 241-286.

Brown and Caldwell, 1997, Completion report for the drilling of two pilot holes and the installation and testing of production well 47 for Carson City Utilities Department: Brown and Caldwell, May 12, 1997, 7 numbered sections.

Brown and Caldwell, 2004, Silver Springs groundwater evaluation prepared for the Carson Water Subconservancy District, Carson City, Nevada: Brown and Caldwell, Carson City, Nev., 13 p.

Brown and Caldwell, 2005, Well \#25B completion report: Brown and Caldwell, Carson City, Nev., 6 numbered sections.

Brown and Caldwell, 2008, Eldorado ASR well \#1: Brown and Caldwell, Carson City, Nev., Section 4.

Cardinalli, J.L., Roach, L.M., Rush, F.E., and Vasey, B.J., 1968, State of Nevada hydrographic areas, in Rush, F.E., Index of hydrographic areas of Nevada: Nevada Division of Water Resources Information Report 6, 33 p.

Cashmen, P.H., and Fontaine, S.A., 2000, Strain partitioning in the northern Walker Lane, western Nevada and northeastern California: Tectonophysics, v. 326, p. 111-130.

Cohen, Phillip, 1963, Specific-yield and particle-size relations of Quaternary alluvium Humboldt River Valley Nevada: U.S. Geological Survey Water-Supply Paper 1669-M, 24 p. 
Davis, S.N., and DeWeist, R.J.M., 1966, Hydrogeology: New York, N.Y., John Wiley \& Sons, Inc., 463 p.

Eco:logic, 2008, Anderson Ranch/Hells Bells Road induction monitoring/test wells: memorandum Sept. 4, 2008, Eco:logic Engineering, LLC, Reno, Nevada, 28 p., 1 appendix.

Eco:logic, 2010, Drilling, construction and testing of two east Dayton monitoring/test wells: memorandum June 15, 2010, Eco:logic Engineering, LLC, Reno, Nevada, 28 p.

Freeze, R.A., and Cherry, J.A., 1979, Groundwater: Englewood Cliffs, N.J., Prentice-Hall, 604 p.

Fritz, Peter, and Fontes, Jean-Charles, eds., 1980, Handbook of environmental isotope geochemistry - The terrestrial environment: New York, Elsevier, v. 1, 545 p.

Glancy, P.A., and Katzer, T.L., 1976, Water-resources appraisal of the Carson River basin, Western Nevada: Nevada Division of Water Resources, Reconnaissance Report 59, $126 \mathrm{p}$.

Halford, K.J., and Kuniansky, E.L., 2002, Documentation of spreadsheets for the analysis of aquifer pumping and slug test data: U.S. Geological Survey Open-File Report 02-197, 54 p.

Halford, K.J., Weight, W.D., and Schreiber, R.P., 2006, Interpretation of transmissivity estimates from single-well pumping aquifer tests: Groundwater, v. 44, no. 3, p. 467471.

Harrill, J.R., Welch, A.H., and Preissler, A.M., 1993, Hydrogeochemical evidence for subsurface inflow to Stagecoach Valley, Lyon County, Nevada: in Selected papers in the hydrologic sciences, 1988-92: U.S. Geological Survey Water-Supply Paper 2340, p. 179-193.

Harrill, J.R., and Preissler, A.M., 1994, Groundwater flow and simulated effects of development in Stagecoach Valley, a small, partly drained basin in Lyon and Storey Counties, western Nevada: U.S. Geological Survey Professional Paper 1409-H, 74 p.

Helsel, D.R. and Hirsch, R.W., 1992, Statistical methods in water resources: New York, Elsevier Science Publishing, 522 p.

Henry, C.D., and Faulds, J.E., 2010, Ash-flow tuffs in the Nine Hill, Nevada, paleovalley and implications for tectonism and volcanism of the western Great Basin, USA: Geosphere, v. 6, no. 4, p. 339-369.

Jeton, A.E., in press, Precipitation and runoff simulations of selected perennial and ephemeral watersheds in the middle Carson River basin, Eagle, Dayton, and Churchill Valleys, west-central Nevada: U.S. Geological Survey Scientific Investigations Report 2011-5066.
John, D.A., Stewart, J.H., Kilburn, J.E., Silberling, N.J., and Rowan, L.C., 1993, Geology and mineral resources of the Reno $1^{\circ}$ by $2^{\circ}$ quadrangle, Nevada and California: U.S. Geological Survey Bulletin 2019, 65 p.

LeBaugh, J.W., and Rosenberry, D.O., 2008, Chapter 1, Introduction and characteristics of flow, in LaBaugh, J.W., and Rosenberry, D.O., eds., Field techniques for estimating water fluxes between surface water and groundwater: U.S. Geological Survey techniques and methods 4-D2, 128 p.

Lohman, S.W., 1972, Groundwater hydraulics: U.S. Geological Survey Professional Paper 708, 70 p.

Lohman, S.W. and others, 1972, Definitions of selected groundwater terms: U.S. Geological Survey Water Supply Paper 1988, 21 p.

Lopes, T.J., and Allander, K.K., 2009, Hydrologic setting and conceptual hydrologic model of the Walker River basin, west-central Nevada: U.S. Geological Survey Scientific Investigations Report 2009-5155, 84 p.

Maurer, D.K., 1985, Gravity survey and depth to bedrock in Carson Valley, Nevada-California: U.S. Geological Survey Water-Resources Investigations Report 84-4202, 20 p.

Maurer, D.K., 1997, Hydrology and groundwater budgets of the Dayton Valley hydrographic area, west-central Nevada: U.S. Geological Survey Water-Resources Investigations Report 97-4123, 89 p.

Maurer, D.K. 2002, Results of test drilling in the basalt aquifer near Fallon, Nevada: U.S. Geological Survey Fact Sheet 048-02, 4 p.

Maurer, D.K., and Berger, D.L., 1997, Subsurface flow and water yield from watersheds tributary to Eagle Valley hydrographic area, west-central Nevada: U.S. Geological Survey Water-Resources Investigations Report 97-4191, $56 \mathrm{p}$.

Maurer, D.K., and Berger, D.L., 2007, Water budgets and potential effects of land and water-use changes for Carson Valley, Douglas County, Nevada, and Alpine County, California: U.S. Geological Survey Scientific Investigations Report 2006-5305, 61 p.

Maurer, D.K., Berger, D.L., Paul, A,P., and Mayers, C.J., 2009, Analysis of streamflow trends, groundwater and surfacewater interactions, and water quality in the upper Carson River basin, Nevada and California: U.S. Geological Survey Scientific Investigations Report 2008-5238, 192 p.

Maurer, D.K., Berger, D.L, and Prudic D.E., 1996, Subsurface flow to Eagle Valley from Vicee, Ash, and Kings Canyons, Carson City, Nevada, estimated from Darcy's Law and the chloride-balance method: U.S. Geological Survey WaterResources Investigations Report 96-4088, 74 p. 
Maurer, D.K., and Halford, K.J., 2004, Updated estimates of the distribution of average annual precipitation in Carson Valley, 1971-2000, Douglas County, Nevada, and Alpine County, California: Journal of the Nevada Water Resources Association, v. 1, no. 1, p. 20-39.

Maurer, D.K., Lopes, T.J, Medina, R.L., and Smith, J.L. 2004, Hydrogeology and hydrologic landscape regions of Nevada: U.S. Geological Survey Scientific Investigations Report 2004-5131, 35 p.

Maurer, D.K., and Thodal, C.E., 2000, Quantity and chemical quality of recharge, and updated water budgets, for the basin-fill aquifer in Eagle Valley, western Nevada: U.S. Geological Survey Water-Resources Investigations Report 99-4289, 46 p.

Maurer, D.K. and Welch, A.H., 2001, Hydrogeology and geochemistry of the Fallon basalt and adjacent aquifers, and potential sources of basalt recharge: U.S. Geological Survey Water-Resources Report 01-4130, 72 p.

Moore, J.G., 1969, Geology and mineral deposits of Lyon, Douglas, and Ormsby Counties, Nevada: Nevada Bureau of Mines and Bulletin 75, 42 p.

Morris, D.A., and Johnson, A.I., 1967, Summary of hydrologic and physical properties of rock and soil materials, as analyzed by the hydrologic laboratory of the U.S. Geological Survey, 1948-60: U.S. Geological Survey Water-Supply Paper 1839-D, 42 p.

Morrison, R.B., 1964, Lake Lahontan - Geology of southern Carson Desert, Nevada: U.S. Geological Survey Professional Paper 401, 156 p.

Morrison, R.B., 1991, Quaternary stratigraphic, hydrologic, and climatic history of the Great Basin, with emphasis on Lakes Lahontan, Bonneville, and Tecopa, in Morrison, R.B., ed., The Geology of North America, Quaternary Nonglacial Geology - Conterminous U.S.: Geological Society of America, v. K-2, p. 283-320.

Muntean, T.W., 2001, Evolution and stratigraphy of the Neogene Sunrise Pass Formation of the Garderville sedimentary basin, Douglas County, Nevada: University of Nevada, Reno, Master’s thesis, May, 2001, 207 p.

National Oceanic and Atmospheric Administration, 1999, Gravity, 1999 edition, vol. 1 - Land and global: National Geophysical Data Center and National Ocean Service, digital data CD.

National Oceanic and Atmospheric Administration, 2002, Monthly station normals of temperature, precipitation, and heating and cooling degree days, 1971-2000, Climatology of the United States, No. 81, Nevada: Asheville, North Carolina, National Climatic Data Center, 26 p.
Pease, R.C., 1980, Geologic map, Genoa quadrangle, Nevada: Nevada Bureau of Mines and Geology Urban Map Series, Genoa Folio, Map 1Cg, scale 1:24,000.

Ponce, D.A., 2004, Chapter 6, Geophysical methods and application, in Assessment of metallic mineral resources in the Humboldt River basin, northern Nevada: U.S. Geological Survey Bulletin 2218, p. 71-98.

Rantz, S.E., 1982, Measurement and computation of streamflow: Volume 1, measurement of stage and discharge: U.S. Geological Survey Water-Supply Paper 2175, 284 p.

Reheis, M.C., 1999, Extent of Pleistocene lakes in the western Great Basin: U.S. Geological Survey Map-File Report 2323, 1:800,000.

Rogers, D.K., 1975, The Carson Lineament - Its influence on recent left-lateral faulting near Carson City, Nevada: Geological Society of America, Abstracts with Programs, v. 7, no. 7, p. 1250.

Schaefer, D.H., and Whitney, Rita, 1992, Geologic framework and groundwater conditions in basin-fill aquifers of the Dayton Valley and Churchill Valley hydrographic areas, Western Nevada: U.S. Geological Survey Water-Resources Investigations Report 91-4072, 12 p.

Schaefer, D.H., Green, J.M, and Rosen, M.R., 2007, Hydrologic settings and groundwater flow simulations of the Eagle Valley and Spanish Springs Valley regional study areas, Nevada, Section 3, in Paschke, S.S. ed., Hydrogeologic settings and groundwater flow simulations for regional studies of the transport of anthropogenic and natural contaminants to public-supply wells - studies began in 2001: U.S. Geological Survey Professional Paper 1737A, 288 p.

Shamberger, H.A., 1972, The story of the water supply for the Comstock: U.S. Geological Survey Professional Paper 779, $52 \mathrm{p}$.

Stewart, J.H., 1988, Tectonics of the Walker Lane belt, western Great Basin: Mesozoic and Cenozoic deformation in a zone of shear, in Ernst, W.G., ed., Metamorphism and crustal evolution of the western United States, Rubey vol. 7: Englewood Cliffs, New Jersey, Prentice-Hall, p. 683-713.

Stewart, J.H., 1999a, Geologic map of the Carson City $30 \times$ 60 minute quadrangle, Nev.: Nevada Bureau of Mines and Geology, Map 118, 1:100,000.

Stewart, J.H., 1999b. Text and references to accompany Nevada Bureau of Mines and Geology Map 118: Nevada Bureau of Mines and Geology, Map 118, 12 p.

Stewart, J.H., and Carlson, J.E., 1978, Geologic map of Nevada: U.S. Geological Survey, prepared in cooperation with the Nevada Bureau of Mines and Geology, 1:500,000 scale, 2 sheets. 
Surpless, Benjamin, 2008, Modern strain localization in the central Walker Lane, western United States: implications for the evolution of intraplate deformation in transtensional settings: Tectonophysics, vol. 457, p. 239-253.

Telford, W.M., Geldart, L.P. Sheriff, R.E., and Keys, D.A., 1976, Applied geophysics: Cambridge University Press, Cambridge, New York, 860 p.

Thiel Engineering, 2004, Cardelli municipal well pump test report: Thiel Engineering Consultants, Reno, Nev., August 2004, 18 p.

Thomas, J.M., and Lawrence, S.J., 1994, Groundwater quality and geochemistry in Dayton, Stagecoach, and Churchill Valleys, Western Nevada: U.S. Geological Survey OpenFile Report 93-356, 69 p.
U.S. Geological Survey, 1999, National Elevation Dataset: U.S. Geological Survey data, accessed January 13, 2004, at http://gisdata.usgs.net/ned.

U.S. Geological Survey, 2003, Quaternary fault and fold database of the United States: U.S. Geological Survey Open-File Report 03-417, http://qfaults.cr.usgs.gov/faults/.

U.S. Geological Survey, 2007, National field manual for the collection of water-quality data: U.S. Geological Survey Techniques of Water Resources Investigations Report, Book 9.

Worts, G.F., Jr., and Malmberg, G.T., 1966, Hydrologic appraisal of Eagle Valley, Ormsby County, Nevada: Nevada Department of Conservation and Natural Resources, Water Resources-Reconnaissance Series Report 39, 55 p. 
This page intentionally left blank. 


\section{Appendix A. Location of Selected Wells Encountering Bedrock and Deep Wells Not Encountering Bedrock}

Table A1. Location of selected wells encountering bedrock and deep wells not encountering bedrock.

[Decimal latitude and longitude: North American Datum of 1983. L and surface altitude: North American Vertical Datum of 1988. Water strata: X indicates yes; $\mathrm{N}$ indicates no; ? indicates uncertain. A bbreviations: na, log not available; ne, not encountered; ft, foot; -, not applicable]

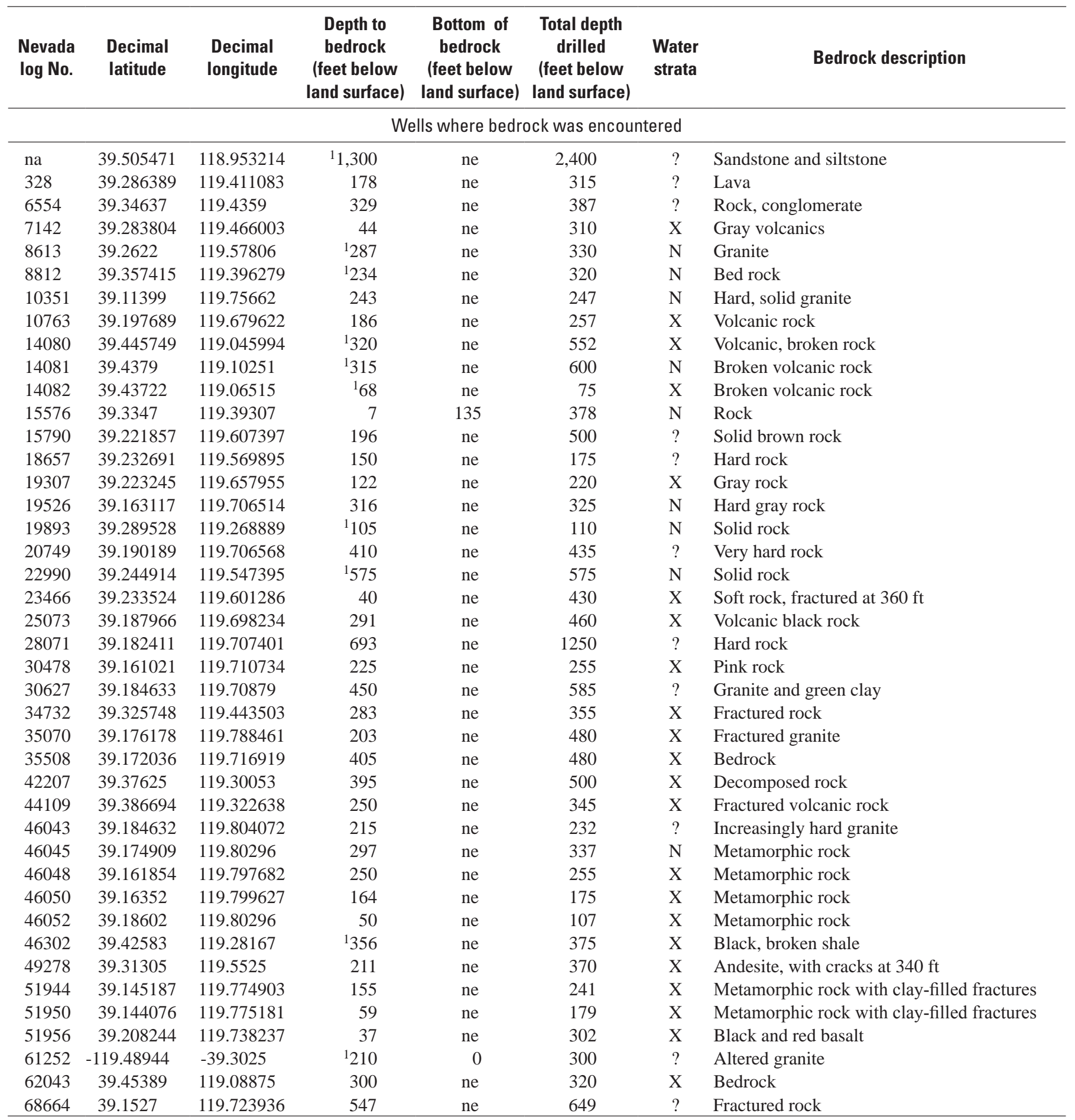


Table A1. Location of selected wells encountering bedrock and deep wells not encountering bedrock.-Continued

[Decimal latitude and longitude: North American Datum of 1983. L and surface altitude: North American Vertical Datum of 1988. Water strata: X indicates yes; $\mathrm{N}$ indicates no, ? indicates uncertain. Abbreviations: na, log not available; ne, not encountered; ft, foot; -, not applicable]

\begin{tabular}{|c|c|c|c|c|c|c|c|}
\hline $\begin{array}{l}\text { Nevada } \\
\text { log No. }\end{array}$ & $\begin{array}{l}\text { Decimal } \\
\text { latitude }\end{array}$ & $\begin{array}{l}\text { Decimal } \\
\text { longitude }\end{array}$ & $\begin{array}{c}\text { Depth to } \\
\text { bedrock } \\
\text { (feet below } \\
\text { land surface) }\end{array}$ & $\begin{array}{c}\text { Bottom of } \\
\text { bedrock } \\
\text { (feet below } \\
\text { land surface) }\end{array}$ & $\begin{array}{c}\text { Total depth } \\
\text { drilled } \\
\text { (feet below } \\
\text { land surface) }\end{array}$ & $\begin{array}{l}\text { Water } \\
\text { strata }\end{array}$ & Bedrock description \\
\hline \multicolumn{8}{|c|}{ Wells where bedrock was encountered_-Continued } \\
\hline 69729 & 39.34784 & 119.43961 & ${ }^{1} 229$ & ne & 309 & $\mathrm{X}$ & Granite, with cracks at $289 \mathrm{ft}$ \\
\hline 74739 & 39.434722 & 119.034722 & 1365 & ne & 395 & $\mathrm{X}$ & Bedrock \\
\hline 84996 & 39.26337 & 119.515 & ${ }^{1} 285$ & ne & 340 & $\mathrm{X}$ & Decomposed lava rock \\
\hline 86098 & 39.38753 & 119.32086 & 302 & ne & 350 & $\mathrm{X}$ & Fractured rock \\
\hline 86135 & 39.44002 & 119.17458 & 212 & 351 & 360 & $\mathrm{X}$ & Brown sandstone, fractured volcanic at $302 \mathrm{ft}$ \\
\hline 87915 & 39.36814 & 119.40822 & 206 & ne & 413 & $\mathrm{X}$ & Bedrock, volcanic \\
\hline 88346 & 39.360944 & 119.20825 & ${ }^{1} 14$ & ne & 160 & $\mathrm{X}$ & Black rock, fractured at $68 \mathrm{ft}$ \\
\hline 88348 & 39.346 & 119.249 & 9 & 267 & 300 & $\mathrm{~N}$ & Black rock \\
\hline 92036 & 39.37467 & 119.245028 & ${ }^{1} 250$ & ne & 430 & $\mathrm{X}$ & Hard black rock, fratured at $350 \mathrm{ft}$ \\
\hline 92045 & 39.33089 & 119.23106 & ${ }^{1} 40$ & ne & 150 & $\mathrm{X}$ & Lava bed \\
\hline 92046 & 39.32964 & 119.23114 & 170 & ne & 130 & $\mathrm{X}$ & Lava bed \\
\hline 92854 & 39.362722 & 119.245028 & 175 & ne & 280 & $\mathrm{X}$ & Bed rock, fractured at $240 \mathrm{ft}$ \\
\hline 93658 & 39.39265 & 119.38103 & ${ }^{1} 15$ & 175 & 580 & ? & Rock \\
\hline 95816 & 39.34198 & 119.46089 & ${ }^{1} 180$ & ne & 220 & $\mathrm{X}$ & Bedrock \\
\hline 96190 & 39.359028 & 119.199556 & 135 & ne & 200 & $\mathrm{X}$ & Bedrock \\
\hline 98091 & 39.332028 & 119.238694 & 176 & ne & 340 & $\mathrm{X}$ & Bedrock, fractured \\
\hline 99379 & 39.43147 & 119.23267 & 14 & ne & 320 & $\mathrm{X}$ & Loose fractured rock \\
\hline 100037 & 39.34919 & 119.20947 & 135 & ne & 200 & $\mathrm{X}$ & Red volcanic rock \\
\hline 100046 & 39.34925 & 119.444889 & 200 & ne & 273 & $\mathrm{X}$ & Rock \\
\hline 101357 & 39.33114 & 119.24039 & 65 & ne & 340 & $\mathrm{X}$ & Reddish rock, broken at $160 \mathrm{ft}$ \\
\hline
\end{tabular}


Table A1. Location of selected wells encountering bedrock and deep wells not encountering bedrock.-Continued

[Decimal latitude and longitude: North American Datum of 1983. L and surface altitude: North American Vertical Datum of 1988. Water strata: X indicates yes; $\mathrm{N}$ indicates no, ? indicates uncertain. A bbreviations: na, log not available; ne, not encountered; ft, foot; -, not applicable]

\begin{tabular}{|c|c|c|c|c|c|c|c|}
\hline $\begin{array}{l}\text { Nevada } \\
\text { log No. }\end{array}$ & $\begin{array}{l}\text { Decimal } \\
\text { latitude }\end{array}$ & $\begin{array}{l}\text { Decimal } \\
\text { longitude }\end{array}$ & $\begin{array}{l}\text { Well depth } \\
\text { (feet below } \\
\text { land surface) }\end{array}$ & $\begin{array}{l}\text { Nevada } \\
\text { log No. }\end{array}$ & $\begin{array}{l}\text { Decimal } \\
\text { latitude }\end{array}$ & $\begin{array}{l}\text { Decimal } \\
\text { longitude }\end{array}$ & $\begin{array}{l}\text { Well depth } \\
\text { (feet below } \\
\text { land surface) }\end{array}$ \\
\hline 5336 & 39.259636 & 119.550173 & 300 & 70678 & 39.37392 & 119.20342 & 181 \\
\hline 6085 & 39.29755 & 119.50565 & 500 & 71150 & 39.38056 & 119.30525 & 415 \\
\hline 10114 & 39.273248 & 119.518227 & 373 & 82728 & 39.415167 & 119.26814 & 480 \\
\hline 10144 & 39.2659 & 119.571387 & 222 & 89470 & 39.36892 & 119.19331 & 220 \\
\hline 13135 & 39.358804 & 119.391279 & 272 & 93663 & 39.28957 & 119.52764 & 460 \\
\hline 14078 & 39.377194 & 119.192833 & 380 & 95425 & 39.35064 & 119.23394 & 190 \\
\hline 22883 & 39.24066 & 119.57426 & 405 & 95906 & 39.34375 & 119.196111 & 260 \\
\hline 36083 & 39.37 & 119.37501 & 760 & 96431 & 39.34175 & 119.455527 & 260 \\
\hline 47257 & 39.36236 & 119.18686 & 179 & 101427 & 39.355 & 119.23047 & 240 \\
\hline 48435 & 39.2385 & 119.56413 & 483 & 102964 & 39.34439 & 119.44833 & 258 \\
\hline 63880 & 39.23726 & 119.56785 & 503 & 109427 & 39.37268 & 119.35155 & 300 \\
\hline 64862 & 39.37836 & 119.306583 & 455 & 109429 & 39.37772 & 119.34234 & 462 \\
\hline 67706 & 39.34981 & 119.22319 & 180 & & & & \\
\hline
\end{tabular}




\section{Appendix B. Location of Selected Wells Logs Describing Gravel and Cobble, and Clay Layers Greater than $\mathbf{5 0}$ Feet Thick, Layer Depths, and Thicknesses}

Table B1. Location of selected well logs describing gravel and cobble, and clay layers greater than 50 feet thick, layer depths, and thicknesses.

[Decimal latitude and longitude: North American Datum of 1983. Land surface altitude: North American Vertical Datum of 1988. A bbreviation: ft, foot]

\begin{tabular}{|c|c|c|c|c|c|c|c|}
\hline $\begin{array}{c}\text { Nevada } \\
\text { log No. }\end{array}$ & $\begin{array}{l}\text { Decimal } \\
\text { latitude }\end{array}$ & $\begin{array}{l}\text { Decimal } \\
\text { longitude }\end{array}$ & $\begin{array}{l}\text { Land surface } \\
\text { altitude } \\
\text { (ft) }\end{array}$ & $\begin{array}{l}\text { Depth to top } \\
\text { (feet below } \\
\text { land surface) }\end{array}$ & $\begin{array}{c}\text { Depth to } \\
\text { bottom } \\
\text { (feet below } \\
\text { land surface) }\end{array}$ & $\begin{array}{c}\text { Thickness } \\
\text { (ft) }\end{array}$ & Lithologic description \\
\hline \multicolumn{8}{|c|}{ Gravel and cobble layers } \\
\hline 3436 & 39.24288016 & 119.563071 & 4,370 & 85 & 204 & 119 & Sand and cobbles \\
\hline 5336 & 39.259636 & 119.550173 & 4,357 & 52 & 300 & 248 & Gravel \\
\hline 6085 & 39.30026662 & 119.5025944 & 4,309 & 276 & 500 & 224 & Gravel, thin clay zones \\
\hline 6087 & 39.29307456 & 119.5259442 & 4,339 & 80 & 178 & 98 & Coarse gravel \\
\hline 6087 & 39.29307456 & 119.5259442 & 4,339 & 228 & 460 & 232 & Gravel, thin clay zones \\
\hline 6088 & 39.28945395 & 119.5259749 & 4,330 & 50 & 100 & 50 & Gravel \\
\hline 6643 & 39.29203 & 119.51654 & 4,303 & 271 & 504 & 233 & Gravel, thin clay zones \\
\hline 7314 & 39.26864 & 119.52773 & 4,353 & 250 & 600 & 350 & Gravel, cobblestones \\
\hline 20891 & 39.32920761 & 119.4516269 & 4,289 & 180 & 230 & 50 & Gravel \\
\hline 21642 & 39.39168243 & 119.2848754 & 4,339 & 220 & 280 & 60 & Cobbles and sand \\
\hline 21642 & 39.39168243 & 119.2848754 & 4,339 & 0 & 120 & 120 & Cobbles \\
\hline 22990 & 39.24648948 & 119.5490253 & 4,367 & 134 & 250 & 116 & Cobbles and sand \\
\hline 22980 & 39.24648948 & 119.5490253 & 4,367 & 312 & 575 & 263 & Cobbles, sand, cemented zones \\
\hline 22980 & 39.24648948 & 119.5490253 & 4,367 & 404 & 505 & 101 & Sand and cobbles \\
\hline 22991 & 39.25691301 & 119.5636047 & 4,308 & 0 & 62 & 62 & Sand and cobbles \\
\hline 32168 & 39.23192381 & 119.572334 & 4,442 & 0 & 50 & 50 & Gravel, boulders, and sand \\
\hline 36109 & 39.47256829 & 118.9899772 & 4,112 & 150 & 300 & 150 & Gravel \\
\hline 40847 & 39.37009892 & 119.3682293 & 4,341 & 90 & 145 & 55 & Gravel \\
\hline 42045 & 39.37379299 & 119.3775516 & 4,341 & 50 & 75 & 25 & Gravel and boulders \\
\hline 63880 & 39.23557957 & 119.5677704 & 4,420 & 318 & 503 & 185 & Gravel and sand \\
\hline 70785 & 39.33670945 & 119.4284017 & 4,361 & 0 & 183 & 183 & Sand, gravel, and boulders \\
\hline 73815 & 39.37370082 & 119.3961132 & 4,342 & 260 & 314 & 54 & Gravel \\
\hline 76352 & 39.38446174 & 119.3079605 & 4,442 & 375 & 470 & 95 & Gravel \\
\hline 78362 & 39.37744748 & 119.3821293 & 4,378 & 58 & 239 & 181 & Gravel \\
\hline 78362 & 39.37744748 & 119.3821293 & 4,378 & 251 & 320 & 69 & Gravel \\
\hline 82712 & 39.36418539 & 119.1662177 & 4,170 & 15 & 71 & 56 & Gravel and sand \\
\hline 82723 & 39.31542887 & 119.2432004 & 4,209 & 147 & 240 & 93 & Gravel and sand \\
\hline 84087 & 39.38416038 & 119.2094737 & 4,180 & 0 & 80 & 80 & Sand and cobbles \\
\hline 84092 & 39.3408608 & 119.3866402 & 4,257 & 0 & 160 & 160 & Sand and cobbles \\
\hline 84092 & 39.3408608 & 119.3866402 & 4,257 & 170 & 260 & 90 & Cobbles \\
\hline
\end{tabular}


Table B1. Location of selected well logs describing gravel and cobble, and clay layers greater than 50 feet thick, layer depths, and thicknesses.-Continued

[Decimal latitude and longitude: North American Datum of 1983. L and surface altitude: North American Vertical Datum of 1988. A bbreviation: ft, foot]

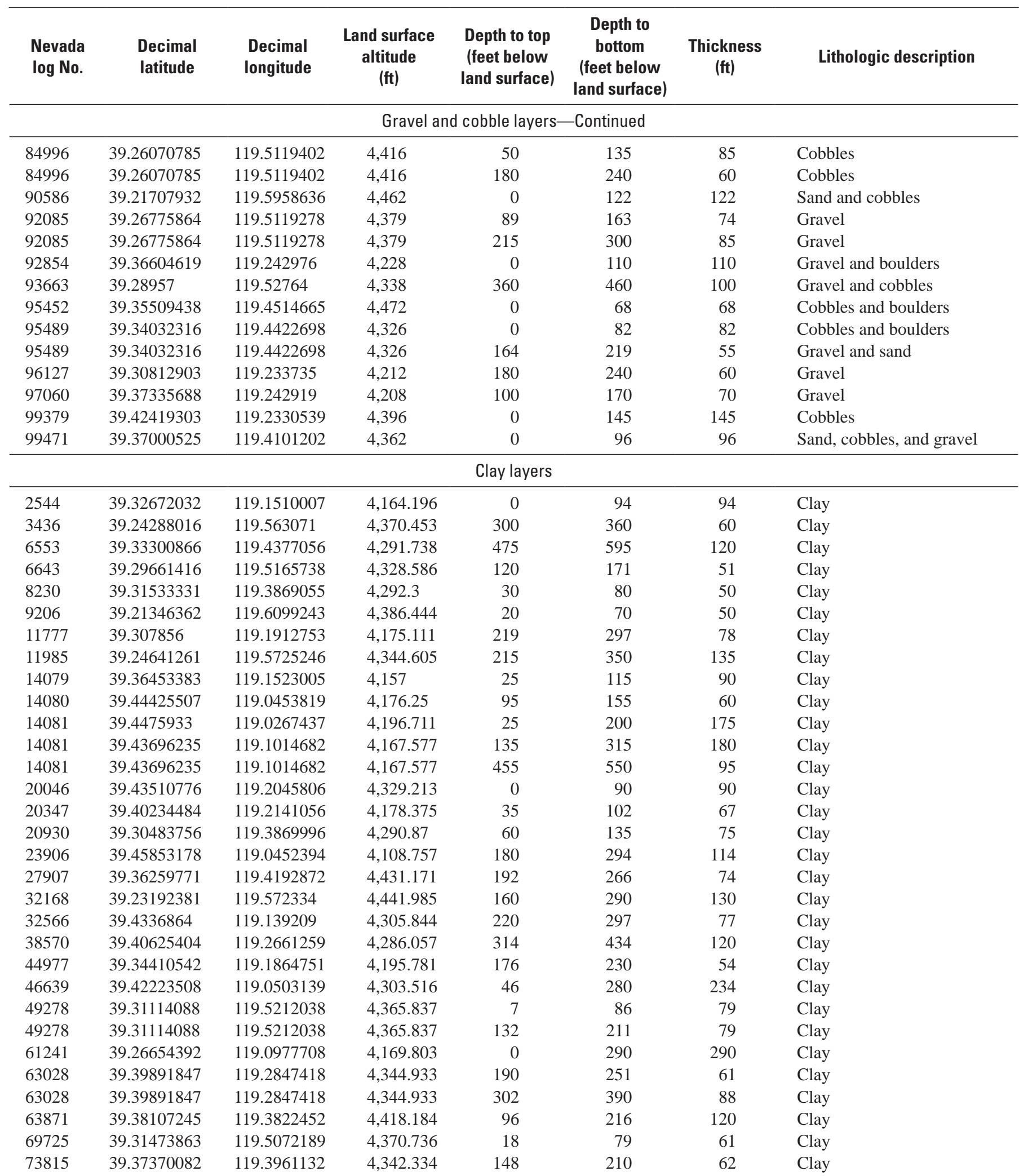


Table B1. Location of selected well logs describing gravel and cobble, and clay layers greater than 50 feet thick, layer depths, and thicknesses.-Continued

[Decimal latitude and longitude: North American Datum of 1983. Land surface altitude: North American Vertical Datum of 1988. A bbreviation: ft, foot]

\begin{tabular}{|c|c|c|c|c|c|c|c|}
\hline $\begin{array}{c}\text { Nevada } \\
\text { log No. }\end{array}$ & $\begin{array}{l}\text { Decimal } \\
\text { latitude }\end{array}$ & $\begin{array}{l}\text { Decimal } \\
\text { longitude }\end{array}$ & $\begin{array}{l}\text { Land surface } \\
\text { altitude } \\
\text { (ft) }\end{array}$ & $\begin{array}{l}\text { Depth to top } \\
\text { (feet below } \\
\text { land surface) }\end{array}$ & $\begin{array}{c}\text { Depth to } \\
\text { bottom } \\
\text { (feet below } \\
\text { land surface) }\end{array}$ & $\begin{array}{c}\text { Thickness } \\
\text { (ft) }\end{array}$ & Lithologic description \\
\hline \multicolumn{8}{|c|}{ Clay layers-Continued } \\
\hline 74730 & 39.42638445 & 119.1344911 & $4,346.625$ & 37 & 346 & 309 & Clay \\
\hline 76352 & 39.38446174 & 119.3079605 & $4,441.901$ & 4 & 365 & 361 & Clay \\
\hline 79709 & 39.42594403 & 119.0501366 & $4,255.622$ & 100 & 300 & 200 & Clay \\
\hline 84087 & 39.38416038 & 119.2094737 & $4,179.983$ & 80 & 265 & 185 & Clay \\
\hline 86087 & 39.30816461 & 119.2100253 & $4,220.982$ & 30 & 85 & 55 & Clay \\
\hline 86087 & 39.30816461 & 119.2100253 & $4,220.982$ & 140 & 190 & 50 & Clay \\
\hline 86135 & 39.44155951 & 119.176724 & $4,287.287$ & 57 & 212 & 155 & Clay \\
\hline 87938 & 39.40078986 & 119.129682 & $4,293.438$ & 130 & 210 & 80 & Clay \\
\hline 96127 & 39.30812903 & 119.233735 & $4,211.844$ & 100 & 160 & 60 & Clay \\
\hline 99135 & 39.27502538 & 119.5637427 & $4,347.678$ & 6 & 105 & 99 & Clay \\
\hline
\end{tabular}


Publishing support provided by the U.S. Geological Survey

Publishing Network, Tacoma Publishing Service Center

For more information concerning the research in this report, contact the Director, Nevada Water Science Center

U.S. Geological Survey

2730 N. Deer Run Road

Carson City, Nevada 89701

http://nevada.usgs.gov/ 
옹

음

꿀

옥

葫

홍

음

음

क्ष

言

국

롫

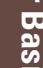

P.

蛋

5

魯

2

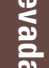

$\infty$

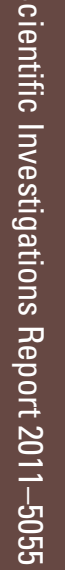

